\title{
CONTROLE DE Tetranychus urticae KOCH COM FUNGOS ENTOMOPATOGÊNICOS
}

\section{MARCO ANTONIO TAMAI}

Tese apresentada à Escola Superior de Agricultura “Luiz de Queiroz", Universidade de São Paulo, para obtenção do título de Doutor em Ciências, Área de Concentração: Entomologia.

P I R A C I C A B A

Estado de São Paulo - Brasil

Janeiro - 2002 


\section{CONTROLE DE Tetranychus urticae KOCH COM FUNGOS ENTOMOPATOGÊNICOS}

\section{MARCO ANTONIO TAMAI}

Engenheiro Agrônomo

Orientador: Prof. Dr. SÉRGIO BATISTA ALVES

Tese apresentada à Escola Superior de Agricultura "Luiz de Queiroz", Universidade de São Paulo, para obtenção do título de Doutor em Ciências, Área de Concentração: Entomologia.

P I R A C I C A B A

Estado de São Paulo - Brasil

Janeiro - 2002 
Dados Internacionais de Catalogação na Publicação (CIP)

DIVISÃO DE BIBLIOTECA E DOCUMENTAÇÃO - ESALQ/USP

Tamai, Marco Antonio

Controle de Tetranychus urtic a e Koch com fungos entomopatogênicos /

Marco Antonio Tamai. - - Piracicaba, 2002.

144 p. : il.

Tese (doutorado) - Escola Superior de Agricultura Luiz de Queiroz, 2002. Bibliografia.

1. Áca ros parasitos de plantas 2. Controle biológico 3. Fungos

entomopatogênicos 4. Pragas de plantası. Título

CDD 632.6542

"Permitida a cópia total ou parcial deste documento, desde que citada a fonte - $\mathrm{O}$ autor" 


\begin{abstract}
A DEUS
Aos meus pais, Siniti, Maria Vera (in memorian) e Verônica

Aos meus irmãos Carlos, Cristiane, Júlio César (in memorian) e Viviane À Mônica Cagnin Martins
\end{abstract}

Ofereço e Dedico

Quando você ver milhares de flores se abrindo, lembre-se de que Deus faz seu trabalho em silêncio. 


\section{Agradecimentos}

Ao Prof. Dr. Sérgio Batista Alves pela orientação, estímulo, confiança e amizade demonstrada durante nosso convívio.

Aos professores do curso de Pós-Graduação em Entomologia (ESALQ/USP) pelos valiosos ensinamentos e colaborações.

À Faculdade de Engenharia de Ilha Solteira (FEIS/UNESP) e à Escola Superior de Agricultura “Luíz de Queiroz” (ESALQ/USP) pela valiosa contribuição em minha formação profissional.

Ao Prof. Dr. Gilberto José de Moraes e a Pesquisadora Dra. Nemaura Pedrosa Haji por terem sido os primeiros a me incentivar na pesquisa e pela amizade sincera.

À Prof. Marinéia L. Haddad pela orientação nas análises estatísticas.

À Coordenadoria de Aperfeiçoamento de Pessoal de Nível Superior (CAPES) e ao Conselho Nacional de Pesquisa e Desenvolvimento Tecnológico (CNPq), pelas bolsas de estudos que possibilitaram a execução desse trabalho.

A todos os colegas do curso de Pós-Graduação em Entomologia pela amizade, compreensão e incentivos durante este tempo de convivência, em especial aos amigos do Laboratório de Patologia e Controle Microbiano de Insetos: Rogério B. Lopes, Marcel 
R. Tanzini, Daniella Macedo, Ricardo A. Polanczyk, Marcos B. Medeiros, Luciana S. Rossi, Elizabeth Q. Ramos, Marcelo O. Garcia, Adriana Setten, Melissa Faion, Luiz F. L. Padulla, Leonardo M. Berzaghi, Michelle L. Rodrigues, Dennis L. Sinisgalli (in memorian), Alexandre R. C. Manzini e Solange A. Vieira.

Ao Dr. Roberto M. Pereira pela tradução do summary.

Aos funcionários do Setor de Entomologia da ESALQ/USP.

Aos funcionários da biblioteca da ESALQ/USP, especialmente às bibliotecárias Kátia Maria de Andrade Ferraz, Eliana Maria Garcia e Sílvia M. Zinsly, pela colaboração na revisão da Tese.

Aos amigos de "república" Marc Jacquemin, Alexsandro Zidko, Guilherme Mitidieri, Luciano J. Ribeiro, Roberto O. Sophia, Luiz C. Monobi, pela amizade e incentivo.

A todos que de alguma forma contribuíram para a realização desse trabalho. 


\section{SUMÁRIO}

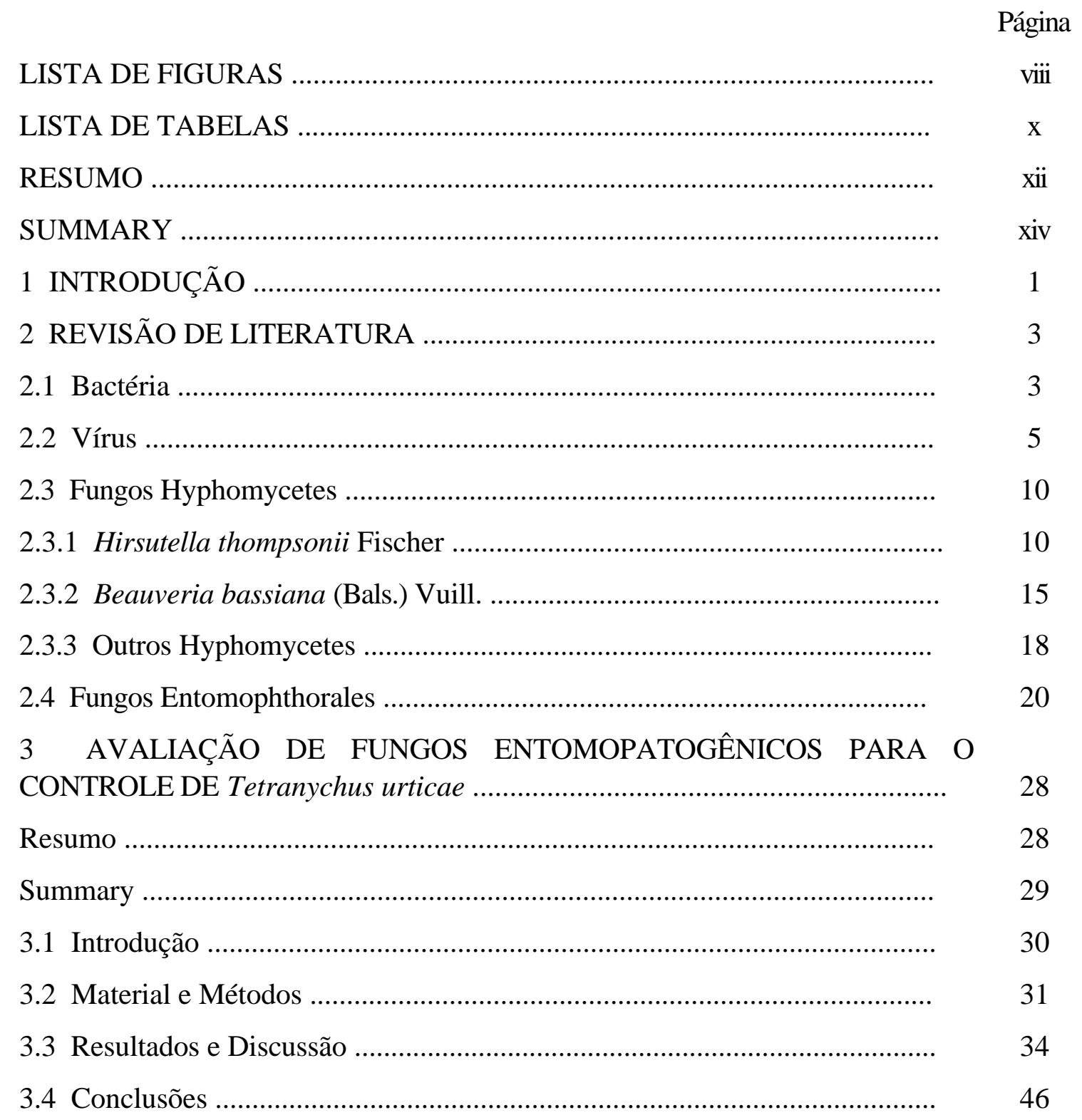


4 AVALIAÇÃO DA PATOGENICIDADE DE CONÍDIO, BLASTÓSPORO E CÉLULA DE LEVEDURA DE Beauveria bassiana PARA Tetranychus urticae 47

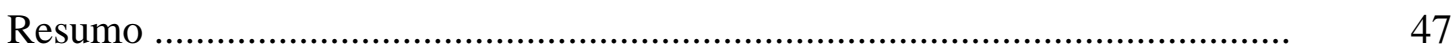

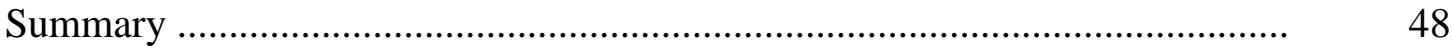

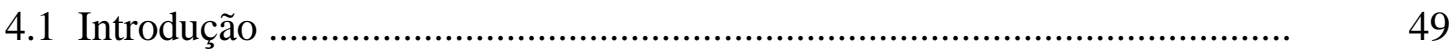

4.2 Material e Métodos ............................................................................... $\quad 50$

4.3 Resultados e Discussão ......................................................................... 55

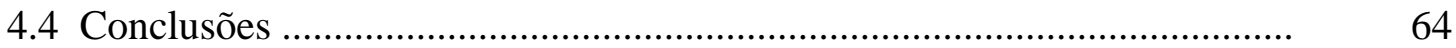

5 TOXICIDADE DE PRODUTOS FITOSSANITÁRIOS PARA Beauveria

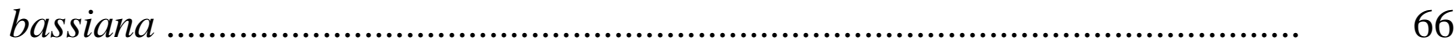

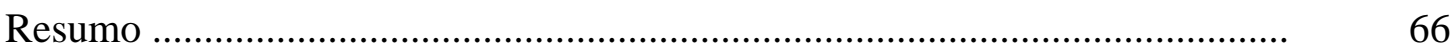

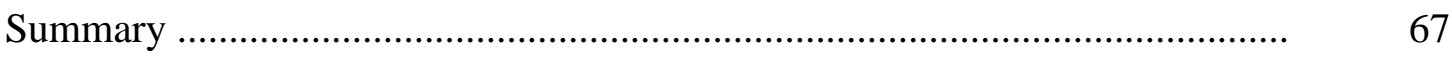

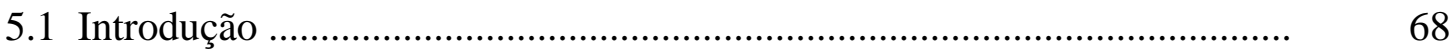

5.2 Material e Métodos ...................................................................... $\quad 70$

5.3 Resultados e Discussão ......................................................................... $\quad 72$

5.4 Conclusões ....................................................................................... 88

6 USO DE Beauveria bassiana PARA O CONTROLE DE Tetranychus urticae NAS CULTURAS DO CRISÂNTEMO E MORANGO EM ESTUFA .............. 89

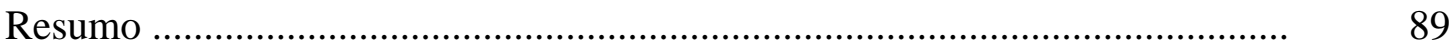

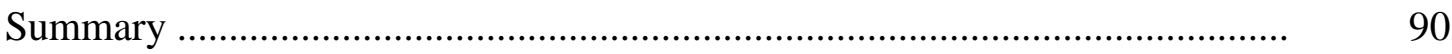

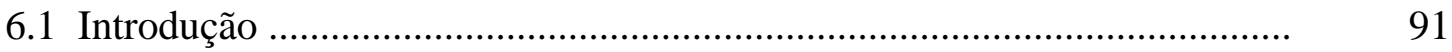

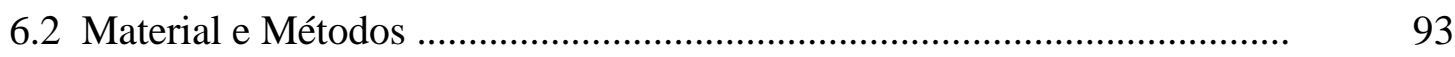

6.2.1 Controle de T. urticae na cultura do crisântemo de corte .......................... 93

6.2.2 Controle de T. urticae na cultura do morango .......................................... 97

6.3 Resultados e Discussão ........................................................................... 99

6.3.1 Controle de T. urticae na cultura do crisântemo de corte ........................... 99

6.3.2 Controle de T. urticae na cultura do morango .......................................... 108

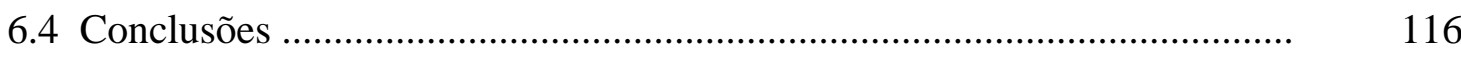

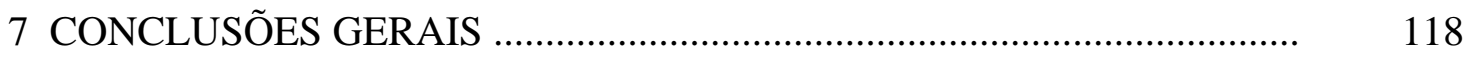

REFERÊNCIAS BIBLIOGRÁFICAS _.................................................... 119 


\section{LISTA DE FIGURAS}

Página

1 Porcentagem de mortalidade acumulada corrigida de Tetranychus urticae, aos 3 e 5 dias após a inoculação com conídios dos 45 isolados de fungos entomopatogênicos. Cor clara $\left(3^{\underline{0}} \mathrm{dia}\right)$; Cor escura $\left(5^{-} \mathrm{dia}\right)$.........................

2 Cristais de cálcio formados no interior de Tetranychus urticae pela colonização do ácaro por Beauveria bassiana. Cristais de formato alongado (A) e bipiramidal (B)

3 Caixa plástica contendo discos de folha de Canavalia ensiformis infestadas com Tetranychus urticae (A); detalhe dos discos de folhas acondicionados nas placas de acrílico (B)

4 Ciclo de Beauveria bassiana em meio de cultura MacConkey (Alves et al., 2002. Comunicação Pessoal)

5 Cadáveres de Tetranychus urticae apresentando esporulação de Beauveria bassiana (A); ovos de Tetranychus urticae com sintomas de infecção por Beauveria bassiana (B) e sem sintomas de infecção (C)

6 Curva de concentração-mortalidade de Tetranychus urticae pela inoculação das estruturas infectivas (conídio, blastósporo e células de levedura) produzidas por Beauveria bassiana

7 Crescimento de colônias de Beauveria bassiana, isolado PL63, sob o efeito de formulações de produtos fitossanitários, e sua classificação de toxicidade. ACompatível; B- Moderadamente Tóxico; C- Tóxico; D- Muito tóxico ....... 
8 A) Estufa contendo os canteiros de matrizes de crisântemo e parcelas experimentais; B) Plantas de crisântemo em cultivo adensado

9 Densidade populacional de Tetranychus urticae por folha de crisântemo avaliada com $0,7,14,21$ e 28 dias do início do experimento para os tratamentos testemunha, químico e Beauveria bassiana ...............................

10 Tetranychus urticae (A) e pulgão morto (B) nas parcelas tratadas, e com a esporulação do fungo Beauveria bassiana, isolado PL63

11 Densidade populacional de Tetranychus urticae por folíolo de morango em função dos momentos de avaliação $(0,7,14$ e 21 dias do início do experimento) 


\section{LISTA DE TABELAS}

Página

1 Hospedeiros e procedências dos 45 isolados de fungos entomopatogênicos utilizados nos bioensaios de seleção com Tetranychus urticae

2 Porcentagem de mortalidade acumulada (corrigida e confirmada) de Tetranychus urticae e porcentagem de ácaros mortos contendo cristais, pela inoculação com 45 isolados dos fungos entomopatogênicos

3 Procedência e hospedeiro dos isolados de Beauveria bassiana utilizados nos bioensaios com Tetranychus urticae

4 Análise de Probit da mortalidade de Tetranychus urticae expostos às três estruturas infectivas (conídio, blastósporo e célula de levedura) produzidas por cinco isolados de Beauveria bassiana (307, 457, 489, 494 e PL63) ........

5 Análise de Probit da mortalidade de Tetranychus urticae expostas às estruturas infectivas produzidas por Beauveria bassiana

6 Valores de "T" para classificação do efeito de produtos químicos sobre fungos entomopatogênicos (Alves et al., 1998b)

7 Toxicidade de formulações de produtos fitossanitários utilizados em culturas hortícolas no Brasil para Beauveria bassiana, isolado PL63, em condições de laboratório

8 Relação de produtos utilizados no tratamento químico e programa de utilização

9 Análise de variância para tratamentos (testemunha, químico e Beauveria bassiana) e momentos de avaliação $(0,7,14,21$ e 28 dias do início do experimento) 
10 Densidade média de Tetranychus urticae por folha de crisântemo para os tratamentos (testemunha, químico e Beauveria bassiana) considerando as cinco avaliações $(0,7,14,21$ e 28 dias do início do experimento) conjuntamente

11 Porcentagem de eficiência de controle (Henderson \& Tilton, 1955) de Tetranychus urticae por Beauveria bassiana (isolado PL63) e químico em canteiros para a produção de mudas de crisântemo no município de HolambraSP, em 1998

12 Quadro da análise de variância para os fatores agente de controle (testemunha, Beauveria bassiana, Metarhizium anisopliae e Vertimec $18 \mathrm{CE}$ ), variedade de morango (Sequóia, Dover, Firne, Campinas e Princesa Isabel), tempo (0, 7, 14 e 21 dias do início do experimento) e bloco (1, 2 e 3$)$

13 Efeito de Beauveria bassiana, Metarhizium anisopliae e Vertimerc $18 \mathrm{CE}$ sobre Tetranychus urticae em folíolos de morango ao longo dos 21 dias

14 Efeito da variedade de morango sobre a população de Tetranychus urticae ..

15 Número médio de Tetranychus urticae por folíolo no tratamento testemunha das diferentes variedades de morango e momentos de avaliação

16 Número médio de Tetranychus urticae por folíolo no tratamento Beauveria bassiana, isolado PL63 $\left(5 \times 10^{7}\right.$ conídios $\left./ \mathrm{mL}\right)$, das diferentes variedades de morango e momentos de avaliação

17 Número médio de Tetranychus urticae por folíolo no tratamento Beauveria bassiana, isolado PL63 $\left(1 \times 10^{8}\right.$ conídios $\left./ \mathrm{mL}\right)$, das diferentes variedades de morango e momentos de avaliação 


\title{
CONTROLE DE Tetranychus urticae KOCH COM FUNGOS ENTOMOPATOGÊNICOS
}

\author{
Autor: MARCO ANTONIO TAMAI \\ Orientador: Prof. Dr. SÉRGIO BATISTA ALVES
}

\section{RESUMO}

Dentre 45 isolados de Hyphomycetes testados, oito de Beauveria bassiana e quatro de Metarhizium anisopliae causaram em Tetranychus urticae, mortalidades superiores a 80 e 90\%, respectivamente, cinco dias após a inoculação na concentração de $5 \times 10^{7}$ conídios/mL. Hirsutella sp. atingiu $73 \%$ de mortalidade na concentração de $1,7 \times 10^{7}$ conídios/mL. Entre 80 a $100 \%$ dos cadáveres de ácaros colonizados pelos isolados de $B$. bassiana e M. anisopliae apresentavam, internamente, cristais de cálcio. Conídio aéreo, blastósporo e célula de levedura de cinco isolados $B$. bassiana foram patogênicos a esta praga. Diferenças significativas $(\mathrm{P} \geq 0,05)$ para $\mathrm{CL}_{50}$ e coeficiente angular entre os isolados

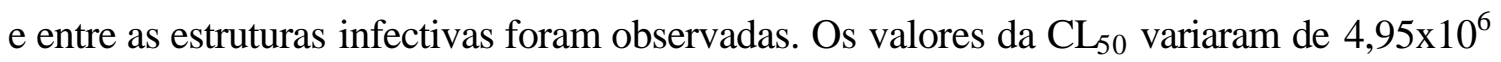
a $8,21 \times 10^{7}$ estruturas infectivas/mL. Não houve diferença significativa entre as estruturas infectivas para os dois parâmetros avaliados, contudo, houve diferenças significativas para a $\mathrm{CL}_{50}$ entre as estruturas infectivas em um mesmo isolado de B. bassiana. Três formulações de fungicidas, 24 de inseticidas e/ou acaricidas foram compatíveis com $B$. bassiana, sendo formulados com as seguintes moléculas: propamocarb hidrocloreto, enxofre, abamectin, acefato, acetamiprid, betacyflutrin, bifentrina, ciromazina, 
deltametrina, diafentiuron, diflubenzuron, dimetoato, fenpropatrina, fenpyroximate, fenvalerate, imidacloprid, metamidofós, propargite, tebufenozide e triclorfon. Houve grande variação na toxicidade dos produtos dentro de cada grupo químico e produtos formulados com a mesma molécula química. B. bassiana foi eficiente no controle de $T$. urticae em crisântemo (Dendranthema grandiflora) cultivado em estufa, quando pulverizado na concentração de $2 \times 10^{8}$ conídios $/ \mathrm{mL}$. O controle microbiano foi superior ao proporcionado pelo controle químico utilizado na propriedade agrícola. Efetuando-se quatro pulverizações do fungo em um período de 14 dias, a densidade reduziu de 1,8 para 0,1 ácaro/folha. Na cultura do morango (Fragaria spp.) a eficiência de B. bassiana foi inferior ao crisântemo, com densidade média de ácaros ao longo de 21 dias de avaliação para as concentrações $1 \times 10^{8}$ e $5 \times 10^{7}$ conídios $/ \mathrm{mL}$ de 13 ácaros/folíolo, contra 43 ácaros/folíolo nas parcelas não tratadas. As variedades de morango Campinas e Princesa Isabel foram as que apresentaram as menores densidades do ácaro, contudo, não houve evidência de que estas variedades interferiram na eficiência de controle da praga por $B$. bassiana. Assim, M. anisopliae, B. bassiana e Hirsutella sp. foram os fungos mais promissores para serem formulados como micoacaricidas para o controle de T. urticae. 


\title{
CONTROL OF Tetranychus urticae KOCH WITH ENTOMOPATHOGENIC FUNGI
}

\author{
Author: MARCO ANTONIO TAMAI \\ Adviser: Prof. Dr. SÉRGIO BATISTA ALVES
}

\section{SUMMARY}

Among 45 isolates of hyphomycetes tested against Tetranychus urticae, 8 Beauveria bassiana and 4 Metarhizium anisopliae isolates caused mortality $>80$ and $90 \%$, respectively, 5 days after inoculation with $5 \times 10^{7}$ conidia/mL. Hirsutella sp. caused $73 \%$ mortality at a concentration of $1.7 \times 10^{7}$ conidia $/ \mathrm{mL}$. Eighty to $100 \%$ of cadavers infected by $B$. bassiana or $M$. anisopliae isolates had calcium crystals inside their bodies. Conidia, blastospores and yeastlike cells of five $B$. bassiana isolates were pathogenic against this pest. Significant differences $(P \geq 0.05)$ were observed among the $\mathrm{LC}_{50}$ 's and slopes of dose-mortality lines for the different isolates and infective structures. $\mathrm{LC}_{50}$ values ranged from $4.95 \times 10^{6}$ to $8.21 \times 10^{7}$ cells $/ \mathrm{mL}$. There were no significant differences among the infective structures in the two tested variables. However, there were significant differences among the $\mathrm{LC}_{50}$ 's with different infective structures within the same B. bassiana isolate. Three fungicide formulations and 24 insecticides and/or mitecides were compatible with $B$. bassiana including those with the following active ingredients: propamocarb hydrochloride, sulphur, abamectin, acephate, 
acetamiprid, betacyfluthrin, bifenthrin, cyromazine, deltamethrin, diafentiuron, diflubenzuron, dimethoate, fenpropathrin, fenpyroximate, fenvalerate, imidacloprid, methamidophos, propargite, tebufenozide and trichlorfon. There was large variability in the toxicity of products withing a chemical group and products containing the same active ingredient. B. bassiana was an efficient $T$. urticae mite control in chrysanthemum (Dendranthema grandiflora), when applied at a concentration of $2 \times 10^{8}$ conidia/mL. Microbial control was better than that provided by chemical pesticides normally used in the greenhouses. With four fungal sprays within 14 days, the mite density was reduced from 1.8 to 0.1 mite/leaf. In strawberry (Fragaria sp.), T. urticae control was lower than in chrysanthemum, with mean density of mites for 21 days after application of $1 \times 10^{8}$ or $5 \times 10^{7}$ conidia/mL at 13 mites/leaflet, compared to 43 mites/leaflet in control plots. The strawberry varieties "Campinas" and "Princesa Isabel" had the lowest mite densities, however, these varieties did not affect the efficacy of mite control by B. bassiana. Thus, M. anisopliae, B. bassiana and Hirsutella sp. were the most promissing fungi to be formulated as mycomiticides for T. urticae control. 


\section{INTRODUÇÃO}

O controle biológico de pragas exige, para seu sucesso, uma boa compreensão das características das pragas e dos inimigos naturais, como interagem entre si e com os demais componentes do sistema (doenças, ervas daninhas, ambiente) e fatores de produção (controle fitossanitário, irrigação, adubação entre outros). Esta forma de abordagem do problema de pragas caracteriza-se o Manejo Integrado (MIP). Ao contrário do controle químico, que de modo geral, é pouco afetado por estes fatores, quando se trabalha com organismos vivos a sua compreensão torna-se importante e necessária.

Geralmente, cada cultura possui características próprias que tornam necessário o desenvolvimento de estratégias especificas de utilização de inimigos naturais, imprescindível para que se possam gerar pacotes tecnológicos eficientes para o uso destes organismos. Pode-se assim reduzir o ceticismo que envolve sua aplicabilidade, tanto por parte do produtor tradicional como de técnicos, apesar de inúmeros casos de sucessos devidamente comprovados.

A necessidade de se adequar o sistema de produção para o uso de inimigos naturais é uma boa oportunidade de se repensar e compreender melhor todo o funcionamento do sistema, como forma de solucionar problemas antigos como a resistência de pragas e doenças aos produtos químicos, excesso de resíduos destes produtos nos alimentos, entre outros. Além disso, deve-se lembrar que o mercado não é tão específico como se imagina, contudo, mais complexo, com demanda por produtos diferenciados, como é o caso de produtos orgânicos isentos de resíduos químicos. O que se propõe é uma integração harmoniosa das diferentes estratégias de controle de pragas, 
de modo a tornar todo o sistema mais eficiente, saudável e econômico, com vantagens para todos da cadeia produtiva.

Deste modo, o objetivo deste trabalho foi o de gerar informações necessárias para que se possa manejar populações do ácaro Tetranychus urticae Koch, praga de importância mundial, com o fungo Beauveria bassiana (Bals.) Vuill. em culturas hortícolas no Brasil. A pesquisa baseia-se na seleção de isolados geneticamente superiores e estudos das estruturas infectivas mais patogênicas deste inimigo natural, bem como na avaliação da toxicidade de produtos fitossanitários a este fungo e determinando sua eficiência para o controle desta praga em situações de produção comercial e experimental. As informações geradas nos capítulos também têm por objetivo preencher algumas das lacunas que dificultam o uso racional deste inimigo natural. 


\section{REVISÃO DE LITERATURA}

Esta revisão aborda os principais agentes de controle microbiano de ácaros fitófagos.

\subsection{Bactéria}

Os trabalhos tratam quase que exclusivamente do efeito da thuringiensina ( $\beta$ exotoxina), uma exotoxina produzida por certas variedades de Bacillus thuringiensis Berliner, durante seu cultivo em meio de cultura. Esta toxina atua como inibidor da produção de RNApolimerase, bloqueando subseqüentemente a mitose celular (Royalty et al., 1990). Os estágios imaturos são mais suscetíveis que o adulto. Em concentrações sub-letais, a toxina provoca anomalias, deformações e alterações teratogênicas em insetos (Habib \& Andrade, 1986). Entretanto, o seu efeito teratogênico observado também em vertebrados e a possível mutagenicidade, levaram as autoridades dos EUA e Canadá a impedirem o uso de linhagens de B. thuringiensis que produzam esta toxina (Burges, 1975). Atualmente, as formulações comerciais desta bactéria são produzidas com linhagens não produtoras da thuringiensina.

Hall et al. (1971) determinaram que o ácaro Panonychus citri (McGregor) (Acari: Tetranychidae) é suscetível ao efeito da thuringiensina, por contato e ingestão. Os ácaros contaminados ficaram paralisados e, quando mortos, o tegumento tornou-se flácido, rompendo-se facilmente quando tocado. Todas as fases de desenvolvimento do ácaro mostraram-se sensíveis à toxina, sendo o efeito proporcional à concentração utilizada. Ovos tratados apresentaram redução na viabilidade dos embriões e na 
sobrevivência das larvas eclodidas. Estudos em casa-de-vegetação mostraram que o material testado foi tóxico por até 45 dias após a aplicação.

A forma de ação da thuringiensina, aparentemente, é diferente de outros acaricidas correntemente utilizados no controle de ácaros pragas. No trabalho de Hoy \& Ouyang (1987) esta toxina mostrou-se tóxica a adultos e jovens de Tetranychus pacificus McGregor e ao seu predador, Metaseiulus occidentalis (Nesbitt) (Acari: Tetranychidae e Phytoseiidae), ambos provenientes de colônias resistentes a diversos acaricidas, causando redução na fecundidade de fêmeas adultas e sobrevivência de larvas. Nesse estudo, ao contrário do observado por Hall et al. (1971), ovos das duas espécies não apresentaram redução na viabilidade dos embriões, entretanto poucas larvas foram capazes de atingir o estágio ninfal, e nenhuma chegou à fase adulta.

Para Tetranychus urticae Koch (Acari: Tetranychidae), Royalty et al. (1990) determinaram que as ninfas (protoninfa e deutoninfa) e fêmeas adultas do ácaro são suscetíveis a thuringiensina quando alimentadas em folhas contendo resíduos da toxína. As fases ninfais apresentaram sensibilidade semelhante entre si, entretanto foram, significativamente, mais sensíveis que o adulto. A thuringiensina apresentou atividade muito lenta sobre os ácaros, com baixo índice de mortalidade em todas as fases, três dias após a aplicação. $\mathrm{O}$ efeito na redução da fecundidade de fêmeas tratadas não foi substancial, mas houve uma relação inversa entre a concentração e postura. $\mathrm{O}$ produto apresentou um forte efeito inibidor sobre a alimentação de fêmeas.

Alguns trabalhos também tratam do efeito supressivo muitas vezes observado sobre populações de ácaros tetraniquídeos, após a aplicação de produtos comerciais contendo $B$. thuringiensis. Estes produtos são compostos quase exclusivamente de uma mistura de cristais proteicos ( $\delta$-endotoxinas) e esporos da bactéria (Habib \& Andrade, 1998) de ação predominante sobre lepídopteros, coleópteros e dípteros pragas. São reconhecidos como de reduzida toxicidade a inimigos naturais (entomopatógenos e artrópodos predadores/parasitóides) (Franz et al., 1980; Hassan et al., 1987; Sterk et al., 1999). De 
acordo com Van Der Geest (1985), o efeito tóxico é atribuído à presença de subprodutos nas formulações, e não à ação direta da bactéria ou de seus produtos metabólicos.

A toxicidade de produtos experimentais e comerciais de B. thuringiensis var. tenebrionis e B. t. var. kurstaki foi avaliada por Chapman \& Hoy (1991) para T. urticae e seu predador M. occidentalis (Acari: Tetranychidae e Phytoseiidae), sendo este último proveniente de colônias resistentes a enxofre, carbaril e diversos produtos fosforados. $\mathrm{O}$ tratamento de fêmeas adultas com duas formulações de $B$. $t$. var. tenebrionis causou, 48 horas após a aplicação, pequena mortalidade em T. urticae, sendo mais tóxico à fêmeas de M. occidentalis. Fêmeas de T. urticae apresentaram em média $90 \%$ de sobrevivência, contra $26 \%$ do predador, na concentração de campo. As duas espécies não sofreram redução na taxa de eclosão de larvas, entretanto apenas $65 \%$ dos imaturos do predador atingiram a fase adulta, contra $88 \%$ de T. urticae. O produto comercial Sandoz Trident ${ }^{\circledR}$ apresentou toxicidade moderada ao predador, com sobrevivência de $58 \%$ na dosagem comercial, enquanto que os produtos Mycogen $\mathrm{M}-\mathrm{ONE}^{\circledR}$ (ambos $B$. $t$. var. tenebrionis) e Dipel $2 \mathrm{X}$ (B. t. var. kurstaki) foram os menos tóxicos, com sobrevivência de $80 \%$ na concentração comercial, contra $90 \%$ no tratamento testemunha.

No trabalho de revisão feito por Van Der Geest et al. (2000), há referência da identificação, nos Estados Unidos, de três isolados de B. thuringiensis produtores de $\delta$ endotoxinas com efeito sobre T. urticae e uma espécie não referida de ácaro que vive na poeira doméstica. Estes autores sugerem que esta toxina possa ser formulada como acaricida comercial ou na criação de plantas transgênicas contendo o gene que codifica a proteína.

\subsection{Vírus}

Doenças causadas por vírus têm sido observadas em poucas famílias de ácaros de importância agrícola, em particular para duas espécies pertencentes a família Tetranychidae: $P$. citri e Panonychus ulmi (Koch). Após um breve período de estudos durante as décadas de 
1950 e 1960, nos Estados Unidos principalmente, o interesse por este grupo de patógenos diminuiu consideravelmente, não sendo avaliado adequadamente sua importância como agente de controle destas duas importantes espécies de ácaros praga.

A primeira constatação da ocorrência destes patógenos foi feita por Muma (1955) em populações de $P$. citri em pomares de citros na Flórida. Os ácaros doentes apresentavam diarréia e, quando mortos, eram observados presos à superfície da folha por uma substância escura, exsudada através do ânus. Alguns anos mais tarde, os mesmos sintomas foram observados em ácaros provenientes de pomares cítricos da Califórnia, muitos dos quais apresentando paralisia e pernas enrijecidas ventralmente (Smith et al., 1959). Estes autores, ao examinarem o centrifugado de suspensões aquosa de ácaros doentes, encontraram partículas semelhantes a vírus, medindo 35 milimicra de comprimento. Posteriormente, Reed \& Hall (1972) demonstraram a presença de partículas de um vírus não-incluso formadas dentro do núcleo das células epiteliais do mesêntero, que posteriormente moviam-se do núcleo para o citoplasma.

A infecção pelo vírus pode ser determinada montando-se os ácaros doentes em meio Hoyer e examinando-os em microscópio de luz polarizada, para a presença ou ausência de cristais birrefringentes presentes no interior do corpo (Beavers \& Reed, 1972). Para situações de campo, Reed et al. (1972a) chegaram a desenvolver um aparelho portátil utilizado para a visualização dos cristais birrefringentes nos ácaros doentes.

Esta doença em $P$. citri encontra-se amplamente distribuída na principal área produtora de citros (laranja, limão, pomelo, tangerina e lima) do Estado da Califórnia, onde este ácaro causa problema econômico, contudo, nenhum fator ambiental ou prática cultural pareceu ser um fator de predisposição para a sua ocorrência natural (Shaw et al., 1968b). Reed (1981) relatou que este patógeno é também comum no Estado do Arizona.

Em condições de laboratório, a transmissão da doença para ácaros sadios pode ser feita de duas formas diferentes: através da inoculação de ácaros sadios em uma colônia com ácaros doentes, ou pela aplicação de uma suspensão aquosa preparada com ácaros doentes macerados sobre colônias de ácaros sadios (Munger et al., 1959). Utilizando-se um "strain" 
albino de P. citri infectado pelo vírus, Gilmore \& Tashiro (1966) determinaram que o período de incubação necessário para que o ácaro inicie a transmissão do patógeno é de dois dias após a inoculação e continua até um a três dias antes de sua morte, correspondendo a um período ótimo de transmissão entre três e quatro dias após a inoculação.

Este patógeno é capaz de infectar todos os estágios de desenvolvimento de $P$. citri, exceto o ovo (Munger et al., 1959). Estudos detalhados conduzidos por Gilmore \& Tashiro (1966), determinaram que este vírus causa grande redução na longevidade e fecundidade de fêmeas, sendo mais intensa quando a infecção ocorre na fase imatura. Contudo, o patógeno apresenta reduzido efeito na fecundidade e mortalidade de três espécies de ácaros predadores desta praga, Euseius hibisci (Chant) (= Amblyseius hibisci), M. occidentalis (= Typhlodromalus occidentalis) e Amblyseius limonicus Garman \& McGregor (Acari: Phytoseiidae), pela ingestão das partículas virais durante a alimentação com presas infectadas.

Epizootias em populações de $P$. citri na Califórnia foram observadas por Tashiro \& Beavers (1966) quando a população do ácaro encontrava-se com 40 a 50 formas móveis por folha. O exame destes ácaros revelou que 54\% dos ácaros vivos e 77\% dos ácaros mortos eram portadores de cristais birrefringentes, entretanto a incidência deveria ser consideravelmente maior, porque nem todos os ácaros doentes produzem cristais. Os autores convenceram-se que a doença tem um papel muito importante na supressão populacional do ácaro, em determinados períodos do ano. A doença nunca desapareceu completamente da população de ácaros, ocorrendo de forma enzoótica durante certos momentos do ano. Observações semelhantes foram feitas por Shaw et al. (1968b) em estudos realizados em cinquenta e um pomares cítricos, em nove municípios do Estado da Califórnia. Altas incidências do vírus estiveram associadas com altas populações do ácaro, observando-se o aumento na incidência quando a população de $P$. citri foi superior a 5 fêmeas/20 folhas. Quando a população era superior a 40 fêmeas/20 folhas, $50 \%$ dos ácaros amostrados estavam-se infectados. A incidência da infecção permaneceu baixa até que altas populações 
do ácaro se desenvolvessem, sendo então seguida por uma drástica redução na população do mesmo.

Beavers \& Reed (1972) comprovaram que o vírus que ocorre em P. citri apresenta elevado grau de especificidade hospedeira, sendo incapaz de infectar e causar a morte em outras espécies de ácaros tetraniquídeos como: P. ulmi, Oligonychus punicae (Hirst), T. urticae, T. pacificus, Tetranychus evansi Baker \& Pritchard e Eotetranychus sexmaculata (Riley). Apenas poucos indivíduos de Tetranychus cinnabarinus Boisduval desenvolveram o cristal característico da doença, e foram também eficazes na transmissão do vírus para ácaros sadios de $P$. citri.

A produção deste vírus para a sua utilização em laboratório e aplicações em campo era feita inicialmente sobre ácaros criados em laboratório. Em decorrência da necessidade de quantidades cada vez maiores, os pesquisadores passaram a utilizar ácaros provenientes do campo. Neste sentido, Reed et al. (1972b) desenvolveram uma forma de incrementar a incidência da doença virótica entre os ácaros coletados, baseada no conhecimento da transmissão do vírus. A infecção do vírus na população do ácaro passou de 30\% no momento da coleta para $92 \%$ quando mantidos por seis dias alimentando-se em frutos frescos de limão com o inóculo.

A capacidade infectiva do vírus obtidos de ácaros doentes coletados no campo e aqueles produzidos em laboratório foram semelhantes (Shaw et al., 1971), contudo, para testes em campo ou que necessitassem de grande quantidade de inóculo, o sistema de produção em laboratório se apresentava antieconômico. Para resolver este problema, foi desenvolvido por Shaw et al. (1971) um aparelho de sucção para a coleta de grandes quantidades de $P$. citri doentes, em condições de campo, que proporcionava uma redução entre 95 a $98 \%$ dos custos, quando comparado à técnica de produção em laboratório. A desvantagem desta técnica, consistia na necessidade de sincronizar as coletas um pouco antes da epizootia atingir o seu acme, o que corresponderia ao momento em que $50 \%$ da população do ácaro se encontrasse infectada. 
Uma das primeiras tentativas de aplicação deste vírus para o controle de $P$. citri em condições naturais foi feita por Gilmore (1965), contudo os resultados foram inconclusivos, devido à ocorrência freqüente de epizootias naturais nas áreas tratadas. Alguns anos mais tarde, Shaw et al. (1968a) conseguiram promover a infecção de ácaros em campo pela pulverização de suspensões de vírus nas concentrações de $0,01 \%(0,1 \mathrm{~g}$ de ácaros doentes/litro de água) e 0,1\% (1g de ácaros doentes/litro de água), e também pela liberação de ácaros infectados nas plantas. Contudo, a técnica da liberação implicava na utilização rápida do ácaro infectado, isso porque a transmissão do vírus começa com dois dias após a infecção e continua até um a três dias antes de sua morte (Gilmore \& Tashiro, 1966). A viabilidade dos vírus presentes no interior dos ácaros infectados diminuiu rapidamente em temperaturas superiores a $40,5^{\circ} \mathrm{C}$, havendo uma completa inativação em temperaturas acima de $46,1^{\circ} \mathrm{C}$ (Reed, 1974).

P. ulmi é outra espécie de ácaro que possuí doenças causadas por vírus. Steinhaus (1959) observou um vírus não-incluso em ácaros coletados na Califórnia-EUA, e posteriormente um vírus diferente foi observado por Putman \& Herne (1966) em OntárioCanadá, que se desenvolvia dentro das células do corpo gorduroso do ácaro (Bird, 1967). Não houve evidencias de que se tratavam da mesma doença nas duas localidades. Ácaros imaturos apresentam-se de coloração vermelho-escuro, porém, os adultos não apresentam alteração de sua coloração natural. Da mesma forma que o vírus que ocorre em $P$. citri, foi observado a presença de inclusões birrefringentes dentro do mesêntero dos ácaros, e as epizootias ocorreram quando a população dos ácaros eram elevadas (Bird, 1967). Putman (1970) obteve considerável redução de $P$. ulmi pela liberação de ácaros infectados em plantas de pêssego infestadas pela praga, contudo, pulverizações de suspensões aquosas contendo partículas virais não tiveram a mesma eficiência. 


\subsection{Fungos Hyphomycetes}

\subsubsection{Hirsutella thompsonii Fischer}

Este fungo é de ocorrência comum em ácaros da família Eriophyidae, causando epizootias naturais em determinadas épocas do ano. A primeira constatação de

$H$. thompsonii foi feita em populações naturais do ácaro-da-ferrugem-dos-citros Phyllocoptruta oleivora (Ashmead) (Acari: Eriophyidae), por Speare \& Yothers (1924) em pomares cítricos na Flórida. Segundo os autores, diversos relatos haviam sido feitos desde 1912, relacionando o desaparecimento repentino do ácaro com o início da estação chuvosa na região. Este fenômeno ocorria no momento em que a população do ácaro era muito elevada no campo, e era precedido por comportamentos incomuns aos indivíduos, caracterizados pela sua agregação em áreas de incidência direta de luz, contrapondo ao hábito da espécie em procurar áreas sombreadas e semi-sombreadas. Este comportamento ocorria com frequiência, previamente ao aparecimento de ácaros mortos no local. Também, foi observado que muitos adultos mudavam a cor, de amarelo-limão para amarelo-laranja ou amarelo-escuro, sendo também observada lentidão nos movimentos.

Mudanças no comportamento normal, é conhecido para diversos artrópodos quando infectados por entomopatógenos. Um fenômeno que lembra muito o comportamento de $P$. oleivora descrito por Speare \& Yothers (1924) é o que se chama de "febre comportamental", que caracteriza-se pela procura, por parte do artrópodo infectado, por locais mais altos e expostos ao sol, num esforço de elevar propositadamente a temperatura do seu organismo para eliminar ou retardar o desenvolvimento do entomopatógeno (Alves \& Pereira, 1998).

Epizootias deste fungo também foram observadas em importantes regiões citrícolas da América do Sul, onde o ácaro P. oleivora constitui-se em uma das pragas-chave desta 
cultura. Assim, a primeira constatação da ocorrência deste patógeno na Argentina foi feita por Sosa-Gómez \& Nasca (1983) em populações naturais na Província de Tucumán. Mais recentemente, Correia et al. (1992) fizeram a constatação em espécimes mortos coletados em pomares cítricos da região de Jaboticabal-SP, nos anos de 1990/91. Outra espécie de eriofiídeo descrita sendo atacada por H. thompsonii no Brasil é Calacarus heveae Feres na cultura da seringueira no Estado do Mato Grosso (Tanzini et al., 2000).

Epizootias têm sido registradas em espécies pertencentes a outras famílias de ácaros de importância agrícola, que não Eriophyidae. Observações de infecção entre 80 a $100 \%$ em populações naturais de Dolichotetranychus floridanus (Banks) (Acari: Tenuipalpidae), foram feitas por Zoebisch et al. (1992), na Costa Rica. Da mesma forma, Cabrera et al. (1987) comprovaram o parasitismo de H. thompsonii em Rhynacus sp. (Acari: Rhyncaphytoptidae), com índice de infecção de $48 \%$ nos ácaros amostrados.

Algumas espécies da família Tetranychidae são descritas como suscetíveis a $H$. thompsonii, inclusive T. urticae. Ao contrário do que ocorre com as espécies de eriofiídeos, não é comum a ocorrência de epizootias naturais em populações destes ácaros, sendo em sua maioria, determinadas em condições de laboratório. Um dos poucos casos que evidenciam a importância deste patógeno na supressão populacional de tetraniquídeos em condições de campo, foi feita por Muma (1955), para a espécie P citri (= Metatetranychus citri), como resultado do levantamento dos inimigos naturais das principais pragas dos pomares de citros da Flórida. No trabalho conduzido por Gerson et al. (1979) determinaram que adultos e ninfas do ácaro carmim, T. cinnabarinus, foram suscetíveis ao fungo, com a maioria dos adultos morrendo no segundo dia após o contato com o patógeno. Posteriormente, Gardner et al. (1982) constataram que a aplicação de um único conídio do fungo sobre o dorso de $T$. urticae, causou mortalidade média de $96,54 \%$ ao sétimo dia após a inoculação, com pico ocorrendo entre o terceiro e quinto dias. Relatos de infecções naturais dos ácaros Mononychellus tanajoa (Bondar) e Oligonychus gossypii (Zacher) por Hirsutella foi feita em Benin, no continente africano por Yaninek et al. (1996). 
Os processos de infecção e desenvolvimento de $H$. thompsonii em P. oleivora e outras espécies de ácaros estão bem documentados. De acordo com McCoy \& Couch (1978), os conídios podem aderir em todas as partes do corpo de P. oleivora e germinar quando em contato com a cutícula. A invasão do hemocele ocorre unicamente através da cutícula, sendo observada a máxima infecção em condições de alta umidade relativa (90 a $100 \%$ ) ou na presença de água livre. O crescimento hifal desenvolve-se inicialmente na região central da hemocele, expandindo-se posteriormente através das pernas e outras regiões do corpo. Após ter ocorrido a penetração do fungo, ocorre alta mortalidade em temperaturas de 23 a $30^{\circ} \mathrm{C}$. Sosa-Gómez \& Nasca (1983) ao estudarem o processo de conidiogênese de $H$. thompsonii em P. oleivora observaram as hifas do fungo saindo do corpo do ácaro pelas regiões anterior e posterior, em alguns casos rompendo o tegumento e emergindo lateralmente. A formação dos conidióforos com os seus respectivos conídios se processa a uma certa distância do ácaro morto, sobre as hifas às quais se fixam à superfície das folhas, mediante rizóides. No interior do corpo dos ácaros, observam-se corpos hifais que eventualmente formam clamidósporos esféricos, que também servem para difundir a doença.

O ciclo de vida de $H$. thompsonii em tetraniquídeos foi estudado por Gerson et al. (1979). Segundo estes autores, os conídios germinam e penetram o tegumento principalmente através da perna, entretanto todas as partes do corpo também servem como locais de penetração. Após a penetração, micélio e corpos hifais do fungo começam a se formar dentro do corpo, preenchendo todo o ácaro em 48 horas, causando assim a sua morte. A conidiogênese do fungo ocorre com 12 a 14 horas após a morte do ácaro, a $26^{\circ} \mathrm{C}$ e $100 \%$ de umidade relativa, inicialmente com o crescimento das hifas presentes no interior do cadáver, que forçam a sua saída para o exterior, no início através das aberturas genital e anal, posteriormente pelas pernas e finalmente por todas as partes do corpo. Estas hifas, ao emergirem do corpo do cadáver, crescem e produzem células conidiogênicas a partir das quais é formado um simples conídio globoso.

Na década de 1970 teve início nos Estados Unidos a produção massal, formulação e aplicação do fungo $H$. thompsonii como micoacaricida para o controle de $P$. oleivora e 
outras espécies de ácaros pragas. De acordo com McCoy \& Couch (1982) a primeira formulação comercial deste fungo disponível nos Estados Unidos foi produzida em 1976 pela Abbott Laboratories (North Chicago, Il) como ABG 6065 e subseqüientemente com o nome

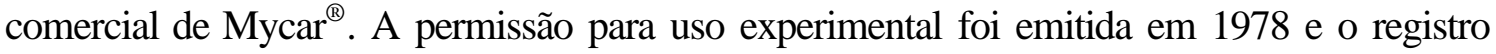
concedido em 1981. Este micoacaricida teve como ingrediente ativo o fungo $H$. thompsonii (strain Fla CBS 556.77b) e foi utilizado por estes autores, durante os anos de 1979 e 1980, nas formulações pó-seco e pó-molhável, para o controle de $P$. oleivora em pomares de laranja "Valência". Os resultados demonstraram que o produto Mycar ${ }^{\circledR}$ foi efetivo em estimular epizootias de H. thompsonii em populações de $P$. oleivora, em várias épocas do ano. $\mathrm{O}$ fungo se estabeleceu nos frutos e folhagens tratadas, ocorrendo neste local o crescimento micelial e conseqüiente conidiogênese. Em um experimento conduzido em 1979, o produto Mycar $^{\circledR}$ causou epizootia prematura na população do ácaro, quatro semanas após a sua aplicação nos pomares. McCoy \& Couch (1978) destacam que o grande número de hospedeiros de $H$. thompsonii foi um ponto importante para a sua industrialização.

Também em citros, Acevedo \& Rosas (2000) observaram redução populacional dos ácaros Brevipalpus phoenicis (Geijskes) e Brevipalpus obovatus Donnadieu (Acari: Tenuipalpidae) quando submetidos a aplicações de $H$. thompsonii, bem como uma diminuição dos danos ocasionados por estes quando submetidos ao tratamento com fungo $(50 \mathrm{~g} / \mathrm{L}$ de micélio e $1 \times 10^{6}$ conídios $\left./ \mathrm{mL}\right)$.

No estudo conduzido por Gardner et al. (1982) o produto Mycar ${ }^{\circledR}$ causou mortalidade entre 75 a $90 \%$ para T. urticae, e 73 a 100\% para Oligonychus ilicis (McGregor) (Acari: Tetranychidae) quando foi aplicado sobre folhagem.

A eficiência deste patógeno em condições de campo é influenciada por diferentes fatores, especialmente temperatura e umidade relativa. A melhor faixa de temperatura para a germinação de conídios, crescimento do micélio e conidiogênese encontra-se entre 25 a $30^{\circ} \mathrm{C}$ (Kenneth et al., 1979). Em trabalhos complementares, Gerson et al. (1979) determinaram que dentro desta faixa térmica, o fungo é capaz de causar maior índice de mortalidade em populações de T. cinnabarinus, e mais rapidamente, normalmente no segundo dia. De acordo 
com estes mesmos autores, para ocorrer a infecção pelo patógeno é necessário a presença de gotas de água ou condições de alta umidade relativa, sendo poucos ácaros infectados em umidade inferior a 98\%. A conidiogênese do fungo em ácaros mortos ocorreu apenas a 98$100 \%$ de umidade relativa.

A seletividade de $H$. thompsonii tem sido estudada para alguns grupos de inimigos naturais, com a finalidade de determinar o impacto de sua utilização em culturas onde ácaros fitófagos são pragas importantes. Neste sentido, Sosa-Gómez et al. (1985) demonstraram que larvas e adultos de Coccidophilus citricola Brethes e Lindorus lophanthae (Blaisdell) (Coleoptera: Coccinellidae), duas espécies de inimigos naturais comuns em agroecossistemas citrícolas em Tucumán-Argentina não foram afetadas por $H$. thompsonii var. thompsonii. Contudo, este fungo é capaz de infectar ácaros predadores como Amblyseius peregrinus (Muma) (= Typhlodromalus peregrinus) (Acari: Phytoseiidae) (McCoy, 1981). Algumas publicações revelam que este patógeno não apresenta riscos a animais de sangue quente (McCoy \& Heimpel, 1980).

Alguns produtos químicos, particularmente fungicidas, usados para o controle de doenças em pomares cítricos, têm sido referidos como responsáveis por aumento populacional de $P$. oleivora. Alguns autores atribuem este fenômeno ao feito dos fungicidas sobre o fungo $H$. thompsonii. A utilização de defensivos químicos compatíveis com o patógeno é de fundamental importância para a proteção deste fungo em pomares cítricos e, consequente redução dos danos causados por P. oleivora. Alves (1986a) relaciona os seguintes produtos químicos, referidos na literatura, como razoavelmente compatíveis com $H$. thompsonii: binapacril, carboxin, sulfato de cobre, PCNB, tiabendazole, oxicloreto de cobre, dinocap, diclorvos, dicofol, omite, plictan e aldicarbe.

No trabalho realizado por Boucias et al. (1982) demonstraram que existe uma grande variação intraespecífica entre as populações naturais de $H$. thompsonii. Através de análises eletroforéticas de doze enzimas presentes no micélio de dezessete isolados geográficos (6 isolados da Flórida, 3 de Cuba, 1 do Texas, 1 da Carolina do Norte, 1 da Jamaica, 1 da Costa do Marfim, 2 da Rodésia, 1 da Nova Guiné, e 1 de Nova Híbride) de $H$. 
thompsonii, observaram que existe uma intensa variabilidade no conteúdo enzímico dos isolados. O coeficiente de similaridade, baseado em amostras enzímicas, obedeceu rigorosamente o modelo morfológico usado para separar $H$. thompsonii em três variedades, entretanto, os resultados mostraram que também ocorre uma extensa diferenciação a nível subcelular entre isolados com as mesmas características morfológicas.

\subsubsection{Beauveria bassiana (Bals.) Vuill.}

B. bassiana é um patógeno amplamente estudado como agente de controle biológico para muitas espécies de insetos pragas, entretanto o seu potencial como micoacaricida não tem sido devidamente avaliado. Testes de campo conduzidos com $T$. urticae (= Tetranychus bimaculatus Harvey), em feijão, mostraram um grande número de ácaros mortos pelo polvilhamento de uma preparação de conídios a $0,5 \%$, sendo ninfas e adultos suscetíveis ao patógeno (Dresner, 1949). O autor observou que ácaros mortos que se encontravam sobre as plantas desprendiam-se facilmente da folha, enquanto que alguns cadáveres apresentavam sintomas de liquefação e crescimento micelial. Os resultados da avaliação, cinco dias após a aplicação do patógeno, revelaram 63,6\% de mortalidade contra $18 \%$ no tratamento testemunha. Alguns ácaros mortos também foram encontrados a uma distância de até dez metros do local onde o fungo foi aplicado.

Nos testes conduzidos por Dyadecho $\left(1958^{1}, 1959^{2,3}\right)$ citados por Lipa (1971), foi demonstrado que o uso de conídios de $B$. bassiana misturado com pequenas concentrações de acaricidas, proporcionou bom controle de Tetranychus spp. e Bryobia rubrioculus (Scheuten) (Acari: Tetranychidae). Quando se aplicou acaricidas (dimetom metil a 0,025\% e

1 DYADECHO, N.P. In: VASSILIEV,V.P. et al. (Ed.). Biologiceskij metod borby s vrediteljami selskochozjastvennych kultur i lesnych nasazdenij. Kisinev: Izdatelstvo Min. Selsk. Choz. Moldavskoj SSR, 1958. p.14-16.

${ }^{2}$ DYADECHO, N.P. In: TELENGA, N.A. (Ed.). Biologiceskij metod borby s vrediteljami rastenij. Kiev: Izdatelstvo Ukrainskoj Akad. Selsk. Nauk, 1959. p.35-41. 
um outro produto à base de enxofre) ou $4 \mathrm{~kg} / \mathrm{acre}$ de uma preparação de conídios, de concentração não conhecida, sobre B. rubrioculus em macieiras, foram moderadamente eficientes, entretanto quando o fungo foi aplicado junto com dimetom metil ou quatro dias após a aplicação do produto contendo enxofre, na metade da concentração recomendada, os resultados foram excelentes. Dois meses após o tratamento, nenhum ácaro foi encontrado nas plantas tratadas, mas altas populações se desenvolveram em plantas não tratadas (Dyadecho, $1958^{1}$ e $1959^{2}$ ). Resultados semelhantes foram observados posteriormente, quando $4 \mathrm{~kg} / \mathrm{acre}$ do mesmo preparado de B. bassiana foi usado junto com $0,025 \%$ de fentiom, para o controle de B. rubrioculus, T. urticae e Tetranychus viennensis Zacher (Acari: Tetranychidae) $\left(\right.$ Dyadecho, $\left.1959^{3}\right)$. De acordo com este pesquisador, o produto químico tornou os ácaros mais suscetíveis à infecção fúngica, de tal modo que altas mortalidades foram obtidas depois de tal tratamento.

Outras espécies de ácaros tem se mostrado suscetíveis ao fungo B. bassiana. Em trabalhos conduzidos por Bartkowski et al. (1988), o ácaro Mononychellus sp. apresentou mortalidade média de 53\%, ao sétimo dia após a inoculação, quando se utilizou um isolado obtido de uma espécie de lepidóptero não especificada pelos autores, na concentração de $1 \times 10^{9}$ conídios $/ \mathrm{mL}$. Este fungo também já foi isolado de Eriophydae spp. (Acari: Eriophyidae) na Itália (Pelagatti et al., 1988).

Rossi et al. (2001) determinaram a patogenicidade de $B$. bassiana ao ácaro $\quad P$. oleivora, sendo os maiores valores de mortalidade observados à partir do terceiro dia, com picos no quarto e quinto dias após a inoculação. Ao quinto dia, os valores de mortalidade corrigida por Abbott (1925) foram de 24, 60, 62, 79 e 91\% quando inoculados nas concentrações de $1 \times 10^{6}, 5 \times 10^{6}, 1 \times 10^{7}, 5 \times 10^{7}$ e $1 \times 10^{8}$ conídios $/ \mathrm{mL}$, respectivamente. Os ácaros mortos, observados em microscópio ótico, apresentavam na região posterior do corpo um grande número de conídios aderidos, com formação de tudo germinativo e micélio se

\footnotetext{
${ }^{3}$ DYADECHO, N.P. Zashchita Rastenii, n.5, p.36-37, 1959.
} 
desenvolvendo em direção ao interior do corpo. A extrusão do patógeno ocorreu por todas as partes do corpo, mas principalmente pela região posterior.

A infecção do ácaro-branco Polyphagotarsonemus latus (Banks) (Acari: Tarsonemidae) foi investigado por Pena et al. (1996). Em condições de laboratório, as CL $_{50}$ para os fungos B. bassiana, H. thompsonii e Paecilomyces fumosoroseus Brown \& Smith foram de $1,16 \times 10^{6}, 2,39 \times 10^{3}$ e $1,29 \times 10^{5}$ conídios $/ \mathrm{mL}$, respectivamente. A mortalidade causada por B. bassiana ocorreu mais rapidamente quando a densidade do ácaro encontravase entre 65 e 125 ácaros por folha. Testes em estufa com estes fungos, mostraram que $B$. bassiana teve a maior e mais persistente efeito na porcentagem de mortalidade do ácaro quando comparado com as demais espécies de fungo.

Recentemente, Tamai (1998) avaliou 152 isolados de diferentes espécies de fungos entomopatogênicos para o controle T. urticae. Os isolados de Metarhizium anisopliae (Metsch.) Sorokin, Paecilomyces lilacinus (Thom.) Samson e Paecilomyces farinosus Dicks. foram pouco patogênicos ao ácaro, quando inoculados em discos de folha na concentração de $1 \times 10^{8}$ conídios $/ \mathrm{mL}$. Contudo, todos os 105 isolados testados de $B$.

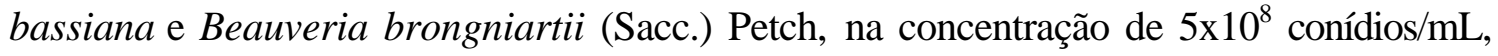
foram patogênicos ao ácaro, com grandes variações na mortalidade. Os valores mínimos e máximos de mortalidade corrigida para os isolados de Beauveria spp., decorridos 4 e 6 dias da inoculação, foram de 1,7 e $97,4 \%$, e de 5,5 e 100\%, respectivamente, o que refletiu a grande variabilidade genética dos isolados avaliados. A partir dessa variação, foi possível selecionar 8 isolados, todos de B. bassiana, altamente patogênicos ao ácaro, que apresentaram valores de mortalidade superiores a 35 e 95\%, ao terceiro e sexto dia após a inoculação, respectivamente.

Um dos isolados selecionados por Tamai (1998) vêm sendo formulado pela empresa brasileira Itaforte Industrial de BioProdutos Agro-Florestais Ltda., e o seu uso experimental tem sido feito para o controle de T. urticae na cultura do mamão no Estado do Espirito Santo. O formulado, segundo a empresa, tem apresentado grande eficiência no controle da praga. Atualmente, estima-se em aproximadamente 4,9 mil hectares a área tratada 
com este entomopatógeno para o controle de T. urticae naquela região (Faria \& Magalhães, 2001). As condições climáticas favoráveis do local (alta umidade relativa e temperaturas moderadas) ao longo de quase todo ano e as restrições do mercado consumidor internacional para a importação de mamão livre de resíduo de produtos fitossanitários químicos, tem sido as grandes fontes de estímulo para o uso deste patógeno na região.

Outro extenso trabalho de seleção de isolados de $B$. bassiana foi conduzido por Oliveira et al. (2000) para o controle do ácaro Oligonychus yothersi (McGregor) (Acari: Tetranychidae), praga da cultura da erva-mate (Ilex paraguariensis ST. Hil.) no Estado do Paraná. Dentre 21 isolados avaliados, também foi observado grande variabilidade quanto a patogenicidade ao ácaro, com valores de mortalidade corrigida entre 30 a $90 \%$, e $\mathrm{TL}_{50}$ variando de 3 a 5 dias quando inoculados na concentração de $1 \times 10^{8}$ conídios $/ \mathrm{mL}$. Desta seleção foi possível selecionar 3 isolados altamente virulentos a praga.

O estudo do processo de infecção e reprodução de B. bassiana em T. urticae, conduzido por Neves et al. (1997), revelou que os conídios do patógeno podem aderir em toda superfície do corpo dos ácaros. 24 horas após a inoculação já se encontravam aderidos e iniciando-se o processo de germinação e de penetração. Entre 24 e 48 horas a maioria dos conídios haviam penetrado o tegumento dos ácaros, e entre 48 a 96 horas, ocorreu a colonização dos mesmos. A fase reprodutiva iniciou-se entre 96 e 120 horas com a formação de micélio sobre o corpo dos ácaros. O início da conidiogênese ocorreu entre 120 a 144 horas, com intensa produção de conídios entre 144 a 168 horas. Assim, as observações ao M.E.V. evidenciaram que o ciclo completo de B. bassiana em T. urticae foi de aproximadamente 144 horas.

\subsubsection{Outros Hyphomycetes}

A infecção dos ácaros Tetranychus neocaledonicus Andre e seu predador Amblyseius ovalis (Evans) (Acari: Tetranychidae e Phytoseiidae) foi obtido por Hanchinal \& 
Manjunatha (2000) com um isolado de M. anisopliae, quando inoculados nas concentrações de $1,5 \times 10^{8}, 1,5 \times 10^{6}$ e $1,5 \times 10^{4}$ conídios/mL do patógeno. As duas espécies de ácaros foram suscetíveis ao patógeno, em suas fases de ovo, ninfas e adulto, sendo a maior mortalidade observada na suspensão mais concentrada. Ao sétimo dia após a inoculação com a maior concentração do fungo, as porcentagens de mortalidades de ninfas e adultos de $T$. neocaledonicus foram de aproximadamente 73 e $93 \%$, respectivamente, enquanto que para o predador as mortalidade foram de 69 e $87 \%$, respectivamente. Na mesma concentração, as porcentagens de mortalidades dos embriões de T. neocaledonicus e A. ovalis ao terceiro dia após a inoculação foram de 88 e $73 \%$, respectivamente.

Sewify \& Mabrouk (1990) demonstraram a patogenicidade de Verticillium lecanii (Zimm.) Viègas ao ácaro-marrom-dos-citros Eutetranychus orientalis (Klein) (Acari: Tetranychidae). Todos os estágios do ácaro foram suscetíveis ao patógeno, inclusive os ovos, quando imersos em uma suspensão contendo $1 \times 10^{7}$ conídios/mL. Os ovos apresentaram alta redução na taxa de eclosão de larvas, especialmente quando incubados a $20^{\circ} \mathrm{C}$. Todas as larvas eclodidas de ovos tratados foram infectadas pelo fungo e morreram. Larvas e adultos morreram entre dois a quatro dias após o tratamento com o patógeno, sendo a $\mathrm{CL}_{50}$ estimada em $1,7 \times 10^{5}$ conídios/mL para a fase adulta. Em condições de casa-de-vegetação, Helyer (1993) observou que V. lecanii é capaz de suprimir populações de T. urticae em condições de alta umidade. Os resultados foram ainda melhores, quando óleo vegetal mais emulsificante foi adicionado à suspensão de conídios.

O fungo $V$. lecanii é muito conhecido no Brasil por infectar diversas espécies de cochonilhas e moscas-brancas que ocorrem em citros, contudo, apenas recentemente descobriu-se que este patógeno é também capaz de infectar o ácaro-da-leprose, $B$. phoenicis. No trabalho de Macedo et al. (2001) ao microscópio eletrônico de varredura (MEV), observaram que a germinação do fungo sobre B. phoenicis ocorreu entre 6 e 48 horas após a inoculação, e o processo de colonização entre 72 e 120 horas, sendo a mortalidade dos ácaros observada a partir desse período. A conidiogênese ocorreu entre 120 e 144 horas, com os conidióforos sendo formados na superfície da cutícula do ácaro. 
Devido a importância dos fungos entomopatogênicos no controle natural das pragas dos citros, Alves et al. (2000) desenvolveram, em colaboração com o Fundecitrus, estudos básicos de compatibilidade de produtos fitossanitários para as espécies M. anisopliae, B. bassiana e $V$. lecanii. Entre 34 produtos fitossanitários registrados para a cultura, 14 apresentaram baixa toxicidade em laboratório para as três espécies de fungos, sendo eles: Decis 25CE (Deltametrina), Kilval 300 (Vamidotion), Kumulus DF (Enxofre), Neoron 500CE (Bromopropilato), Nuvacron 400 (Monocrotofós), Omite 720CE (Propargite), Orthene 750BR (Acefato), Perfekthion (Dimetoato), Roundup (Glifosato), Rufast 50SC (Acrinatrin), Talstar100CE (Bifentrin), Tamaron BR (Metamidofós), Torque 500SC (Óxido de fenbutatina) e Winner (Imidacloprid).

\subsection{Fungos Entomophthorales}

Fungos da ordem Entomophthorales (Divisão Zygomycetes) são importantes patógenos de insetos e ácaros tetraniquídeos em muitas partes do mundo. Um gênero muito conhecido é Entomophthora, e que recentemente foi dividido em diversos gêneros novos dos quais Neozygites é regularmente observado em ácaros tetraniquídeos (Van Der Geest et al., 2000). Pelo menos uma dezena de espécies de ácaros tetraniquídeos pertencentes aos gêneros Eotetranychus, Eutetranychus, Mononychellus, Oligonychus, Panonychus e Tetranychus são relacionados na literatura sofrendo epizootias naturais por estes fungos, dos quais os gêneros Tetranychus, Oligonychus e Eotetranychus juntos, correspondem a quase metade das espécies de ácaros pragas encontradas em dezenove culturas representativas da agricultura em todo o mundo (Yaninek \& Moraes, 1991), comprovando desta maneira a grande importância deste grupo de fungos como agentes de controle natural.

Nesta revisão, a nomenclatura do fungo Entomophthorales será tratada, preferencialmente, como apresentado por Van Der Geest (1985) e Van Der Geest et al. 
(2000). Neste caso, quando o patógeno for apresentado com modificação na nomenclatura de gênero, este será seguido entre parênteses da maneira como foi citado no trabalho original.

Uma das primeiras observações de um fungo desta ordem infectando ácaros tetraniquídeos foi feita por Fisher (1951), no Estado da Flórida. O fungo, uma espécie de Neozygites (= Entomophthora), foi responsável por um índice de mortalidade superior a $70 \%$ em populações naturais de $P$. citri. Desde então, muitas outras espécies de Neozygites têm sido descritas, atacando espécies de ácaros pragas, bem como estudado seu papel na regulação das populações naturais de ácaros desta família.

Nos Estados Unidos, o fungo Neozygites floridana (= Entomophthora floridana) foi descrito por Selhime \& Muma (1966), como sendo um importante agente de controle natural das populações de Eutetranychus banksi McGregor (Acari: Tetranychidae). Em estudos de laboratório, o patógeno apresentou um índice de infecção de $60 \%$ para este ácaro, e de $20 \%$ para a espécie E. sexmaculatus. Assim, esse patógeno pode atacar espécies pertencentes a gêneros diferentes da família Tetranychidae, entretanto com índice de infecção diferente. Esta espécie de fungo também foi observada no Japão, causando epizootias em populações de Oligonychus hondoensis Ehara (Acari: Tetranychidae) (Nemoto \& Aoki, 1975). Ainda nos Estados Unidos, Entomophthora fresenii Nowakowsfi foi descrita em muitas localidades do Alabama, causando mortalidade de até $100 \%$ em populações de T. urticae, especialmente em indivíduos adultos (Carner \& Canerday, 1968).

Uma das primeiras observações destes fungos no Brasil foi feita por Humber et al. (1981), em T. evansi na região de Petrolina-PE. Trata-se de N. floridana $(=$ Triplosporium sp.), e foi observado causando epizootias durante os meses de abril a junho de 1979, correspondendo ao final do período chuvoso na região. Durante esse período, corpos hifais e estruturas reprodutivas do fungo foram observados na maioria dos ácaros mortos.

No ano de 1988, foi observado em campos de mandioca na região central da Bahia, um considerável número de $M$. tanajoa mortos devido a uma epizootia causada por $N$. floridana (= Neozygites sp.). A partir desta constatação, foi conduzida uma investigação adicional, durante fevereiro a junho de 1990, para se determinar a distribuição deste patógeno 
em populações naturais do ácaro. Foram visitados 97 campos de mandioca em diferentes estados do nordeste do Brasil, encontrando-se o ácaro em 82 campos. Desses campos, em 41 foram encontrados ácaros infectados por $N$. floridana. Cerca de $75 \%$ dos campos onde se constatou a presença do fungo, a precipitação anual média variava entre 700 e 1300 mm (Delalibera Júnior et al., 1992).

Outro trabalho de levantamento foi realizado na Índia por Ramaseshiah (1971), durante os anos de 1968 a 1970. O fungo Neozygites sp. near floridana $(=$ Entomophthora sp.) foi observado infectando diferentes espécies de ácaros tetraniquídeos, incluindo $T$. urticae (= T. telarius), Tetranychus sp.1 (possivelmente $T$. cinnabarinus ou T. neocaledonicus) e Tetranychus sp.2 (possivelmente Tetranychus ludeni Zacher). Em algumas oportunidades, o índice de mortalidade em populações naturais de Tetranychus sp.2 (possivelmente T. ludeni) foi de 80 a $100 \%$ dos indivíduos.

Um estudo detalhado do desenvolvimento do fungo $N$. floridana $\quad(=E$. floridana) sobre o ácaro E. banksi, foi conduzido por Selhime \& Muma (1966). Estes autores observaram que a estrutura infectiva do fungo, conhecida como conídio adesivo, fixase às pernas e porções inferiores do corpo, mais freqüentemente na região anterior. Sob condições adequadas, estes conídios germinam, crescem através do tegumento e penetram o hospedeiro. A partir do ponto de penetração, o fungo expande hifas através do corpo do ácaro, dividindo-se posteriormente em corpos hifais que crescem e dividem-se na cavidade do corpo, gnatossoma e pernas, preenchendo inteiramente o corpo do hospedeiro. Ácaros mortos ocorrem, principalmente, associados com grande crescimento interno do fungo. Após a morte, o fungo cresce dentro do cadáver, rompendo o tegumento e produzindo conidióforos externamente. Estes conidióforos produzem conídios primários em condições de alta umidade relativa, que são então lançados a distâncias variáveis do ácaro morto. Dentro destas condições, os conídios primários, ao caírem sobre uma superfície seca, germinam, produzindo um fino e ereto filamento onde é produzido um único conídio adesivo em sua extremidade. Conídios adesivos secundários e terciários podem ser ocasionalmente produzidos a partir dos conídios adesivos primários, sendo menores que os anteriores. Em condições de temperaturas 
constantes de $26^{\circ} \mathrm{C}$ em condições de laboratório, o ciclo completo, que se inicia com a infecção do hospedeiro e termina com a produção de conídios infectivos, varia entre cinco a seis dias.

Informações complementares ao de Selhime \& Muma (1966) quanto ao desenvolvimento de $N$. floridana (= Entomophthora cf. floridana) foram descritas por Carner (1976). De acordo com o autor, com três dias após a inoculação, os corpos hifais preenchem completamente a hemocele de T. urticae, momento em que são observados os primeiros sintomas externos. Estes sintomas são representados por uma diminuição na movimentação do ácaro, e com o seu corpo tornando-se entumecido e empalidecido. As pernas tornam-se rígidas e estendidas, com os pontos vermelhos dos olhos tornando-se difusos. Pouco depois os ácaros morrem, apresentando inicialmente uma coloração mais clara e corpo entumecido, posteriormente tornando-se marrons e mumificados. Esporos de resistência foram observados no final da estação. Os ácaros que produzem esporos de resistência têm sintomas completamente diferentes daqueles que produzem conídios. Estes tornam-se lentos e depois morrem, pretos e brilhantes. Nesse estágio, a cutícula torna-se frágil e quando rompe, libera um líquido escuro sobre a folha. Os esporos recém-formados são marrom brilhantes e tornam-se pretos à medida que ficam mais velhos.

De acordo com Nemoto \& Aoki (1975) com a aproximação do inverno, os corpos hifais do fungo $N$. floridana (= E. floridana) infectando O. hondoensis formam apenas esporos de resistência sem formação de conídios. No inverno, apenas esporos de resistência são observados em ácaros mortos e mumificados. A maior parte das múmias desintegram-se e caem das plantas hospedeiras, mas algumas podem permanecer nos ramos. Ácaros mortos pelo fungo Neozygites sp. near floridana (= Entomophthora sp.) foram observados por Ramaseshiah (1971), fracamente aderidos às folhas, em posição de alimentação ou retidos nas teias produzidas pelos ácaros.

Este grupo de fungo é capaz de infectar todas as fases de desenvolvimento dos ácaros, exceto o ovo (Selhime \& Muma, 1966; Nemoto \& Aoki, 1975), com índice de infecção superior para as formas adultas. Estudos conduzidos em pomares cítricos com o 
ácaro E. banksi, mostraram que o índice de infecção de $N$. floridana (= E. floridana) é maior para fêmeas que para as outras fases de desenvolvimento pós-embrionários. Ao longo do período de amostragem, a infecção em protoninfas foi de até 16,5\%, deutoninfas de 20,2\% e fêmeas de 49,2\% (Selhime \& Muma, 1966). Resultados semelhantes foram observados por Carner \& Canerday (1970), ao estudarem a ocorrência de epizootias de Neozygites sp. (= Entomophthora sp.) em populações de T. urticae. O nível de infecção diferiu com o estágio de desenvolvimento do hospedeiro, apresentando deutoninfas e adultos (fêmeas e machos), infecção duas vezes superior à de protoninfas, enquanto que as larvas foram pouco infectadas. Resultados semelhantes foram observados por Elliot (1998) ao estudar epizootias de $N$. floridana em $M$. tanajoa no Brasil, onde a maioria dos ácaros mortos eram constituídas de fêmeas. De forma contraria, Susilo et al. (1994) constataram que os estágios imaturos de T. urticae são mais suscetíveis a infecção por $N$. floridana do que adultos, e também, que fêmeas adultas são mais suscetíveis do que machos adultos. Os autores sugerem que a menor suscetibilidade dos machos deve-se à sua cutícula mais resistente, quando comparada com às das fêmeas, e também, porque as fêmeas possuem uma cutícula mais elástica necessária para o desenvolvimento do ovário e oviposição.

O fungo $N$. floridana que ocorre infectando $M$. tanajoa nos estados da região nordeste do Brasil apresenta grande especificidade para este ácaro. No estudo conduzido por Moraes \& Delalibera Júnior (1992) este patógeno apresentou reduzida patogenicidade ao ácaro Tetranychus bastosi Tuttle, Baker \& Sabelis (Acari: Tetranychidae), contudo, nenhuma evidência de infecção foi observada para T. urticae e aos ácaros predadores Amblyseius idaeus (Denmark \& Muma) e Amblyseius manihot Moraes (Acari: Phytoseiidae).

Condições de alta umidade relativa do ar são necessárias para que muitas espécies de Entomophthorales possam produzir conídios, ejetar e infectar os seus hospedeiros. As epizootias parecem estar associadas aos meses chuvosos, sendo altas infecções observadas quando são precedidas por um período variável de dias chuvosos (Wilding, 1981). Estudos conduzidos por Nemoto \& Aoki (1975) demonstraram que infecções do fungo $N$. floridana 
(= E. floridana), atacando $O$. hondoensis no Japão, ocorrem especialmente durante a estação chuvosa do ano.

No trabalho desenvolvido por Smitley et al. (1986), os autores definiram as condições ambientais que mais contribuem para a produção de conídios, infecção e patogenicidade de $N$. floridana em $T$. urticae. A conidiogênese apresentou significativa interação com a temperatura e umidade relativa. A faixa ótima de umidade relativa foi de 98 a 100\%, com maior produção de conídios primários a 100\%, enquanto que a faixa favorável de temperatura foi de 15 a $26^{\circ} \mathrm{C}$, com ótimo de $21^{\circ} \mathrm{C}$. Temperatura e umidade relativa necessárias para a formação de conídios adesivos foram similares às exigidas para a produção de conídios primários. Valores elevados de umidade relativa, 90 a 95\%, foram muito favoráveis para a infecção pelos conídios, não tendo sido observados ácaros infectados quando a umidade relativa foi de 25 a $35 \%$, em todas as temperaturas testadas. Nestes testes a temperatura teve pouco efeito na incidência da infecção, entretanto apresentou efeito muito importante na duração das fases do ciclo do fungo. Assim, ácaros mantidos a 10, 20, 30 e $37^{\circ} \mathrm{C}$ morreram com 15, 5, 4 e 7 dias, respectivamente. De forma semelhante, os resultados de uma série de trabalhos de infectividade do fungo N. floridana $(=$ E. floridana $)$ em E. banksi desenvolvidos por Selhime \& Muma (1966), mostraram que houve uma correlação positiva entre umidade e infectividade. Água condensada após os conídios adesivos terem sido produzidos, resultou em alta incidência de infecção.

Uma série de trabalhos sobre o efeito dos fatores ambientais na biologia de $N$. floridana que ocorre em $M$. tanajoa foram publicados. A produção e germinação de conídios primários foram afetados pela temperatura, umidade e fotoperíodo. A produção de conídios aumentou com o incremento da temperatura entre 13 e $23^{\circ} \mathrm{C}$, contudo, nenhum conídio foi formado a 28 e $33^{\circ} \mathrm{C}$. A produção de conídios aumentou, significativamente, com o incremento da umidade, sendo observado a máxima produção quando a umidade foi de 100\%. O número de conídios produzido na condição de luz permanente foi, aproximadamente, 4 vezes menor do que o produzido nas condições de escuro permanente ou fotofase de 12 horas. Entre 82 e 100\% dos conídios produzidos foram ejetados quando os 
cadáveres foram mantidas na condição de 12 horas de fotofase. A germinação dos conídios primários iniciou com 2 horas e aumentou progressivamente com a redução da temperatura de $28(11,2 \%)$ para $13^{\circ} \mathrm{C}(20,1 \%)$. Não houve germinação a $33^{\circ} \mathrm{C}$. Umidade superior a $95 \%$ foi necessária para que houvesse germinação deste tipo de conídio, e a quantidade de conídios germinados aumentou com a elevação da umidade ambiente. Não houve germinação quando os conídios foram mantidos na condição de luz permanente (Oduor et al., 1996a).

Da mesma forma como observado para os conídios primários, Oduor et al. (1996b) demonstraram que a germinação e viabilidade dos capiliconidios (conídios adesivos) de $N$. floridana foram afetados pela temperatura, umidade e fotoperíodo. A germinação dos conídios iniciou com 2 horas após sua adesão aos ácaros, com formação do tubo germinativo em $66 \%$ dos conídios quando mantidos entre 18 e $28^{\circ} \mathrm{C}$, umidade acima de $98 \%$ e escuro. A melhor faixa de temperatura para germinação foi entre 18 e $28^{\circ} \mathrm{C}$ e umidade de $100 \%$, contudo, a germinação reduziu com o tempo de armazenamento. Elevada germinação pode ser obtida desde que os conídios sejam mantidos a baixa temperatura. Foi observado que a germinação no escuro é, significativamente, maior do que na presença de luz.

De acordo com Oduor et al. (1997) o fungo N. floridana é letal a M. tanajoa mesmo quando inoculado com um único conídio adesivo. A mortalidade de ácaros inicia-se após 48 horas da inoculação. Quando inoculados nas doses de 6 a 8 conídios adesivos/ácaro todos os ácaros morreram entre 57 e 63 horas, e entre 69 e 89 horas quando inoculados com 1 a 3 conídios adesivos/ácaro. A porcentagem de mortalidade reduziu progressivamente com a diminuição do número de conídios inoculados.

Uma forma simples de estocagem do fungo $N$. floridana (= Triplosporium floridanum), pode ser feita armazenando os cadáveres infectados (Kenneth et al., 1972). Estes autores observaram que o fungo permanece com a viabilidade inalterada por seis meses quando armazenado a $4^{\circ} \mathrm{C}$ e baixa umidade relativa. Quando os cadáveres foram mantidos em condições ambiente, a $22^{\circ} \mathrm{C}$, verificou-se que, decorrido seis meses, a viabilidade do fungo foi reduzida para 30\%. Resultados semelhantes foram obtidos por Oduor et al. (1995) para $N$. floridana. Este fungo quando armazenado a $4^{\circ} \mathrm{C}$ e baixa umidade relativa, na forma 
de corpos hifais contidos em cadáveres (múmias) não esporulados de $M$. tanajoa, mantiveram-se com elevada viabilidade (90\%) após 16 meses de armazenamento. 


\section{AVALIAÇÃo DE FUNGOS ENTOMOPATOGÊNICOS PARA O CONTROLE DE Tetranychus urticae}

\section{Resumo}

Foram avaliados 45 isolados dos fungos Aschersonia aleyrodis (1), Beauveria bassiana (32), Metarhizium anisopliae (10), Hirsutella sp.(1) e Paecilomyces farinosus (1) quanto à patogenicidade ao ácaro Tetranychus urticae. Os ácaros foram inoculados com suspensões $1,7 \times 10^{7}$ (Hirsutella sp.) ou $5 \times 10^{7}$ conídios $/ \mathrm{mL}$ e mantidos a $25 \pm 1^{\circ} \mathrm{C}$, 98\% UR e 12 horas de fotofase. A. aleyrodis e $P$. farinosus apresentaram reduzida patogenicidade causando mortalidade corrigida inferior a 3\% após cinco dias da inoculação. Todos os isolados de B. bassiana, M. anisopliae e Hirsutella sp. foram patogênicos para T. urticae com seus valores de mortalidade incrementando a partir do terceiro dia, e com acme de mortalidade ocorrendo ao quarto e quinto dias após a inoculação. Para B. bassiana, 19 isolados (59\%) apresentaram valores de mortalidade corrigida ao quinto dia entre 60 a $80 \%$ e apenas oito isolados (25\%) causaram mortalidades superiores a 80\%. Quanto a M. anisopliae, 8 isolados (80\%) apresentaram valores superiores a $80 \%$ de mortalidade corrigida ao quinto dia, sendo que 4 isolados apresentaram mortalidades superiores a 90\%. Hirsutella sp. causou $73 \%$ na concentração de $1,7 \times 10^{7}$ conídios/mL, cinco dias após a inoculação. Observou-se a presença de cristais de cálcio no interior de 80 a $100 \%$ dos ácaros colonizados pelos isolados de B. bassiana e M. anisopliae. 
Palavras-chave: Aschersonia aleyrodis, Beauveria bassiana, Metarhizium anisopliae, Hirsutella, Paecilomyces farinosus, Tetranychus urticae.

\section{EVALUATION OF ENTOMOPATHOGENIC FUNGI FOR CONTROL OF Tetranychus urticae}

\section{Summary}

Forty-five isolates of Aschersonia aleyrodis (1), Beauveria bassiana (32), Metarhizium anisopliae (10), Hirsutella sp. (1) and Paecilomyces farinosus (1) were evaluated for pathogenicity against the mite Tetranychus urticae. The mites were inoculated with suspensions containing $1.7 \times 10^{7}$ (Hirsutella $\mathrm{sp}$.) or $5 \times 10^{7}$ conidia $/ \mathrm{mL}$ (other fungi) and maintained at $25 \pm 1{ }^{\circ} \mathrm{C}, 98 \% \mathrm{RH}$ and $12 \mathrm{~h}$ photofase. A. aleyrodis and P. farinosus had low pathogenicity causing less than 3\% Abbott-corrected mortality five days after inoculation. All isolates of B. bassiana, M. anisopliae and Hirsutella sp. were pathogenic to $T$. urticae with mortalities increasing after the third day and peaking on the fourth or fifth day post inoculation. For B. bassiana, 19 isolates (59\%) caused corrected mortalities between 60 to $80 \%$ after 5 days, and only 8 isolates (25\%) caused corrected mortalities $>80 \%$. For $M$. anisopliae, 8 isolates $(80 \%)$ caused $>80 \%$ corrected mortality after 5 days, and 4 caused $>90 \%$ mortality. Hirsutella sp. caused $73 \%$ mortality 5 days after inoculation with $1.7 \times 10^{7}$ conidia/mL. Calcium crystals were observed inside 80 to $100 \%$ of mites infected with B. bassiana or M. anisopliae.

Keywords: Aschersonia aleyrodis, Beauveria bassiana, Metarhizium anisopliae, Hirsutella, Paecilomyces farinosus, Tetranychus urticae. 


\subsection{Introdução}

Tetranychus urticae apresenta grande capacidade de desenvolvimento de resistência à acaricidas químicos, sendo considerado uma das principais pragas das culturas hortícolas em todo mundo (Jeppson et al., 1975; Cranham \& Helle, 1985). Seus inimigos naturais incluem diversos grupos de artrópodos (insetos e ácaros predadores) e os entomopatógenos. Dentre os artrópodos, destaca-se o ácaro Phytoseiulus persimilis (Acari: Phytoseiidae), utilizado a mais de 30 anos para o controle desta praga em culturas hortícolas produzidas em estufas na Europa, América do Norte e Ásia, sendo um dos inimigos naturais mais comercializados nestes locais (Van Lenteren \& Woets, 1988).

As pesquisas conduzidas com microrganismos causadores de doenças em $T$. urticae concentram-se em dois grupos de fungos. O primeiro é representado por espécies da Ordem Entomophthorales, conhecidas por causarem epizootias em populações de diversas espécies de ácaros da família Tetranychidae. Apesar de sua reconhecida importância, seu potencial como agente de controle têm sido pouco explorado em razão das dificuldades que ainda envolvem sua produção. Esta situação limita a utilização destes fungos à estratégias que preconizam sua proteção no agroecossistema e introdução em áreas onde ainda não ocorrem (controle biológico clássico), como é feito para algumas espécies desta Ordem que infectam insetos (Lacey et al., 2001). No segundo grupo estão os fungos imperfeitos (Deuteromycotina: Hyphomycetes) de amplo espectro hospedeiro e de fácil produção em meios naturais e artificiais, como Beauveria bassiana, Metarhizium anisopliae, Verticillium lecanii e Hirsutella thompsonii. Esses fungos são de ocorrência comum e podem ser facilmente isolados de amostras de solo e de insetos e/ou ácaros infectados, sendo predominantes nas principais coleções de fungos entomopatogênicos no Brasil (ESALQ/USP e Instituto Biológico) (Almeida \& Batista Filho, 2001).

A variabilidade genética dos isolados nessas coleções já foi comprovada, principalmente, quanto aos padrões moleculares e patogenicidade à insetos e ácaros pragas (Almeida et al., 1997; Lopes, 1999; Neves \& Alves, 2000b; Alves et al., 2001a; 
Ramos, 2001), constituindo-se desta maneira em reservatórios diversificados para estudos visando a seleção de materiais que apresentem características adequadas para sua utilização em programas de controle biológico de pragas. Estas características são definidas de acordo com a estratégia de uso do entomopatógenos, em que se considera a bioecologia da praga alvo e as características da cultura e do ambiente em que a praga se encontra.

A estratégia mais comum de uso de fungos entomopatogênicos no controle de pragas é a introdução inundativa, na qual se utilizam grandes quantidades do entomopatógeno para uma rápida supressão da população (Lacey et al., 2001). Esta situação é adequada em se tratando de pragas como $T$. urticae que apresenta grande capacidade biótica, ciclo de vida curto e que ocorre em culturas cujos níveis de dano são muito reduzidos, como nas culturas de ornamentais e olerícolas. Para esta estratégia, o entomopatógeno precisa ser efetivo no controle da praga, de fácil produção e armazenamento. Desse modo, o objetivo desta pesquisa foi o de avaliar a patogenicidade de 45 isolados de cinco espécies de fungos Hyphomycetes ao ácaro T. urticae, com a finalidade de selecionar isolados promissores para uso no controle da praga.

\subsection{Material e Métodos}

Fêmeas adultas recém emergidas de T. urticae foram transferidas de uma criação estoque em plantas de feijão-de-porco, Canavalia ensiformis (Dicotiledonea: Fabaceae), para placas de polietireno de 4,0 cm de diâmetro, contendo cada placa um disco de folha de $C$. ensiformis de $2,5 \mathrm{~cm}$ de diâmetro sobre uma espuma de polietileno umedecida. Cada placa recebeu inicialmente 15 fêmeas do ácaro, sendo após trinta minutos retirados os ácaros mortos e o excedente, mantendo-se apenas 10 ácaros/placa. Em seguida, os ácaros foram pulverizados com suspensões de conídios em Torre de Potter, utilizando-se volume de $2 \mathrm{~mL}$ de suspensão $1,7 \times 10^{7}$ (Hirsutella sp.) ou $5 \times 10^{7}$ conídios/mL (Aschersonia aleyrodis, B. bassiana, M. anisopliae e Paecilomyces

farinosus) e pressão de 15 libras/pol'. Foram avaliados 45 isolados destas espécies de 
fungos entomopatogênicos. Cada isolado (tratamento) foi aplicado em 10 placas, sendo cada placa uma repetição. Após a pulverização, as placas foram mantidas em condição ambiente por 15 minutos para a evaporação da porção líquida da suspensão. Posteriormente, foram acondicionadas dentro de caixa plástica transparente $(34 \mathrm{~cm}$ de comprimento x $22 \mathrm{~cm}$ de largura e $12 \mathrm{~cm}$ de altura). A caixa foi mantida fechada dentro de câmara para B.O.D., sob a temperatura de $25 \pm 1{ }^{\circ} \mathrm{C}, 98 \%$ de UR e 12 horas de fotofase. Diariamente a caixa foi mantida aberta por 30 minutos para a renovação do ar com o ambiente.

As avaliações foram realizadas uma vez ao dia, anotando-se as mortalidades diárias (total, confirmada e corrigida) em cada placa, além da porcentagem de ácaros mortos contendo cristais de cálcio no seu interior. A mortalidade corrigida foi calculada pela fórmula de Abbott (1925), a partir da mortalidade total, enquanto que a mortalidade confirmada correspondeu a porcentagem de ácaros mortos que esporularam de cada tratamento [( $\mathrm{n}^{\mathrm{O}}$ ácaros mortos esporulados $\left.\mathrm{x} 100\right) \div\left(\mathrm{n}^{\mathrm{O}}\right.$ ácaros mortos total $\left.)\right]$. Amostras de 10 a 20 ácaros mortos foram montados em lâmina contendo uma mistura de Hoyer + azul láctico (1:1) para a visualização dos cristais de cálcio em microscópio de contraste de fase. Para a confirmação da morte pelo patógeno, os ácaros mortos foram lavados em álcool $70 \%$ e posteriormente colocados em câmara úmida. A câmara úmida consistiu em uma caixa plástica hermética, com espuma umedecida no fundo.

Os isolados dos fungos entomopatogênicos avaliados (Tabela 1) encontram-se armazenados no Banco de Microrganismos Entomopatogênicos do Instituto Biológico de São Paulo (IB/Campinas-SP) e também no Banco de Patógenos do Laboratório de Patologia e Controle Microbiano de Insetos do Departamento de Entomologia, Fitopatologia e Zoologia Agrícola da ESALQ/USP, em freezer a $-12^{\circ} \mathrm{C}$ na forma de conídios puros. Por ocasião dos testes, os isolados foram inoculados em meio de cultura M.C. (meio completo) (Alves et al., 1998c) e mantidos por 7 dias em câmara B.O.D. a $26 \pm 0,5^{\circ} \mathrm{C}$ e 12 horas de fotofase para o crescimento e produção de conídios. Os conídios produzidos foram removidos da superfície do meio de cultura com auxílio de uma espátula de metal, para o preparo das suspensões em água destilada estéril mais espalhante adesivo (Tween $\left.80^{\circledR}-0,2 \mathrm{~mL} / \mathrm{L}\right)$. 
Tabela 1. Hospedeiros e procedências dos 45 isolados de fungos entomopatogênicos utilizados nos bioensaios de seleção com Tetranychus urticae

\begin{tabular}{|c|c|c|c|}
\hline Espécie & Isolado & Procedência & Hospedeiro \\
\hline A. aleyrodis & 1216 & Guaíra-SP & Bemisia tabaci \\
\hline B. bassiana & CB 2 & Cascavel-PR & Amostra de solo \\
\hline B. bassiana & $\mathrm{CB} 4$ & Cascavel-PR & Amostra de solo \\
\hline B. bassiana & CB 6 & Cascavel-PR & Amostra de solo \\
\hline B. bassiana & CB 7 & Cascavel-PR & Amostra de solo \\
\hline B. bassiana & CB 13 & Cascavel-PR & Amostra de solo \\
\hline B. bassiana & CB 14 & Cascavel-PR & Amostra de solo \\
\hline B. bassiana & CB 15 & Cascavel-PR & Amostra de solo \\
\hline B. bassiana & CB 16 & Cascavel-PR & Amostra de solo \\
\hline B. bassiana & CB 21 & Cascavel-PR & Amostra de solo \\
\hline B. bassiana & CB 23 & Aral Moreira-MS & Amostra de solo \\
\hline B. bassiana & CB 24 & Cascavel-PR & Amostra de solo \\
\hline B. bassiana & CB 44 & Cascavel-PR & Amostra de solo \\
\hline B. bassiana & CB 47 & Cascavel-PR & Amostra de solo \\
\hline B. bassiana & CB 66 & São José Rio Pardo-SP & Hypotheneтus hampei \\
\hline B. bassiana & CB 74 & Japão & Lyzothopteus eryzoperus \\
\hline B. bassiana & CB 75 & Cascavel-PR & Amostra de solo \\
\hline B. bassiana & CB 87 & Goiânia-GO & Cosmopolites sordidus \\
\hline B. bassiana & CB 141 & Cascavel-PR & Amostra de solo \\
\hline B. bassiana & CB 145 & Cascavel-PR & Amostra de solo \\
\hline B. bassiana & CB 146 & Cascavel-PR & Amostra de solo \\
\hline B. bassiana & CB 147 & Cascavel-PR & Amostra de solo \\
\hline B. bassiana & CB 149 & Limeira-SP & Amostra de solo \\
\hline B. bassiana & CB 150 & Cascavel-PR & Amostra de solo \\
\hline B. bassiana & CB 154 & Guaraniaçu-PR & Amostra de solo \\
\hline B. bassiana & CB 157 & Cascavel-PR & Amostra de solo \\
\hline B. bassiana & CB 161 & Guaraniaçu-SP & Amostra de solo \\
\hline
\end{tabular}


Tabela 1. Hospedeiros e procedências dos 45 isolados de fungos entomopatogênicos utilizados nos bioensaios de seleção com Tetranychus urticae (Continuação)

\begin{tabular}{|c|c|c|c|}
\hline Espécie & Isolado & Procedência & Hospedeiro \\
\hline B. bassiana & CB 164 & Espigão Azul-PR & Amostra de solo \\
\hline B. bassiana & CB 165 & Cascavel-PR & Amostra de solo \\
\hline B. bassiana & CB 166 & Cascavel-PR & Amostra de solo \\
\hline B. bassiana & PL 63 & Piracicaba-SP & Atta sp. \\
\hline B. bassiana & 353 & Piracicaba-SP & Pentatomidae (Hemiptera) \\
\hline B. bassiana & 1260 & Itiquira-MT & Leptopharsa heveae \\
\hline Hirsutella sp. & 1282 & Caçú-GO & Calacarus heveae \\
\hline M. anisopliae & CB 345 & Cosmópolis-SP & Mahanarva fimbriolata \\
\hline M. anisopliae & CB 347 & Araras-SP & Mahanarva fimbriolata \\
\hline M. anisopliae & CB 348 & Sertãozinho-SP & Mahanarva fimbriolata \\
\hline M. anisopliae & E6 & Estado de Pernambuco & Diatraea saccharalis \\
\hline M. anisopliae & E9 & Boca da Mata-AL & Mahanarva posticata \\
\hline M. anisopliae & PL47 & Campos-RJ & Mahanarva posticata \\
\hline M. anisopliae & 1037 & Porto Alegre-RS & Solenopsis sp. \\
\hline M. anisopliae & 1247 & Turvínia-SP & Amostra de solo \\
\hline M. anisopliae & 1286 & Valparaíso-SP & Mahanarva fimbriolata \\
\hline M. anisopliae & 1294 & Estado de São Paulo & Mahanarva fimbriolata \\
\hline P. farinosus & 1205 & Santa Fé do Sul-SP & Bemisia tabaci \\
\hline
\end{tabular}

\subsection{Resultados e Discussão}

Os resultados da mortalidade acumulada (corrigida e confirmada) do ácaro T. urticae e a porcentagem de ácaros mortos contendo cristais pela inoculação com 45 isolados dos fungos A. aleyrodis, B. bassiana, M. anisopliae, Hirsutella sp. e $P$. farinosus, encontram-se na Tabela 2 e Figura 1.

Os isolados dos fungos A. aleyrodis e P. farinosus apresentaram valores de mortalidade corrigida ao quinto dia inferiores a 3\%. Apesar dessa baixa patogenicidade a T. urticae, comprovou-se a sua colonização e esporulação sobre os cadáveres do ácaro. 
Assim, quando estes cadáveres foram observados em meio Hoyer + azul láctico, eram visualizados os conídios e conidióforos característicos destas espécies de fungos. A reduzida patogenicidade de A. aleyrodis a $T$. urticae pode ser explicada, em parte, pelo fato desta espécie de fungo entomopatogênico possuir seu espectro hospedeiro composto predominantemente por cochonilhas, pulgões e moscas brancas (Hemiptera: Sternorrhyncha) (Alves, 1998a; Samson et al., 1988). O mesmo não se aplica a $P$. farinosus que apresenta um espectro hospedeiro mais amplo quando comparado com $A$. aleyrodis, distribuídos entre espécies de lepidópteros, coleópteros, himenópteros e homópteros (Boucias \& Pendland, 1998). No caso deste fungo outros fatores estão envolvidos. É importante considerar que o número de isolados avaliados destes fungos foi muito reduzido, não podendo generalizar estes resultados para toda a espécie.

Todos os isolados das espécies B. bassiana, M. anisopliae e Hirsutella sp. foram patogênicos a fêmeas do ácaro $T$. urticae, com valores de mortalidade corrigida aumentando progressivamente com o tempo após a inoculação. Não houve mortalidade de ácaros na avaliação realizada 24 horas após a inoculação. Ao segundo dia, a mortalidade média corrigida foi inferior a 5\% nos tratamentos. Os valores incrementaram a partir do terceiro dia, sendo o acme de mortalidade observado ao quarto e quinto dias após a inoculação pelos isolados. 
Tabela 2. Porcentagem de mortalidade acumulada (corrigida e confirmada) de Tetranychus urticae e porcentagem de ácaros mortos contendo cristais, pela inoculação com 45 isolados dos fungos entomopatogênicos

\begin{tabular}{|c|c|c|c|c|c|c|c|c|c|}
\hline \multirow{3}{*}{ Isolados } & \multicolumn{9}{|c|}{ Dias após a Inoculação (D.A.I.) } \\
\hline & \multicolumn{3}{|c|}{3 D.A.I. } & \multicolumn{3}{|c|}{4 D.A.I. } & \multicolumn{3}{|c|}{5 D.A.I. } \\
\hline & Corrig $^{1}$ & Conf $^{2}$ & $\overline{\text { Cristais }}$ & Corrig & Conf & Cristais & Corrig & Conf & Cristais \\
\hline E6 & 25,3 & 72,4 & 100,0 & 56,5 & 80,6 & 100,0 & 62,1 & 42,8 & 100,0 \\
\hline E9 & 31,5 & 75,7 & 100,0 & 57,3 & 84,0 & 100,0 & 81,9 & 86,9 & 100,0 \\
\hline CB 02 & 20,0 & 87,5 & 100,0 & 76,1 & 94,4 & 100,0 & 87,4 & 72,7 & 100,0 \\
\hline CB 04 & 0,0 & 100,0 & 100,0 & 21,6 & 76,7 & 80,0 & 38,1 & 64,7 & 90,0 \\
\hline CB 06 & 23,2 & 83,3 & 100,0 & 60,2 & 78,0 & 60,0 & 76,2 & 40,0 & 83,3 \\
\hline CB 07 & 4,3 & 33,3 & 100,0 & 47,2 & 85,4 & 100,0 & 74,7 & 80,8 & 100,0 \\
\hline CB 13 & 16,3 & 39,1 & 88,9 & 56,2 & 76,3 & 100,0 & 80,7 & 95,6 & 100,0 \\
\hline CB 14 & 9,1 & 90,0 & 100,0 & 34,1 & 93,7 & 80,0 & 52,4 & 72,2 & 80,0 \\
\hline CB 15 & 11,1 & 83,3 & 80,0 & 55,7 & 57,1 & 80,0 & 79,8 & 68,2 & 100,0 \\
\hline CB 16 & 6,5 & 100,0 & 100,0 & 56,3 & 92,0 & 100,0 & 79,2 & 95,6 & 100,0 \\
\hline CB 21 & 6,5 & 100,0 & 100,0 & 51,3 & 97,8 & 100,0 & 75,0 & 100,0 & 100,0 \\
\hline CB 23 & 18,5 & 52,0 & 80,0 & 49,4 & 76,7 & 100,0 & 79,5 & 82,1 & 100,0 \\
\hline CB 24 & 4,5 & 100,0 & 100,0 & 54,3 & 96,0 & 100,0 & 77,1 & 95,6 & 100,0 \\
\hline CB 44 & 5,4 & 76,9 & 100,0 & 40,4 & 76,5 & 100,0 & 68,7 & 81,5 & 100,0 \\
\hline CB 47 & 4,5 & 75,0 & 100,0 & 53,3 & 97,9 & 100,0 & 78,1 & 100,0 & 100,0 \\
\hline PL 47 & 17,0 & 100,0 & 100,0 & 67,3 & 100,0 & 100,0 & 94,8 & 100,0 & 100,0 \\
\hline PL 63 & 14,2 & 81,2 & 70,0 & 49,3 & 89,2 & 90,0 & 73,6 & 91,7 & 90,0 \\
\hline CB 66 & 0,0 & 0,0 & 0,0 & 19,0 & 88,9 & 100,0 & 26,5 & 100,0 & 100,0 \\
\hline CB 74 & 17,4 & 62,5 & 100,0 & 50,6 & 75,0 & 100,0 & 72,3 & 85,7 & 100,0 \\
\hline CB 75 & 6,5 & 100,0 & 100,0 & 58,4 & 79,2 & 100,0 & 81,3 & 88,5 & 100,0 \\
\hline CB 87 & 1,0 & 100,0 & 100,0 & 1,1 & 27,3 & 33,3 & 10,7 & 25,0 & 66,7 \\
\hline CB 141 & 36,0 & 86,1 & 100,0 & 56,8 & 95,6 & 90,0 & 69,6 & 92,3 & 80,0 \\
\hline CB 145 & 1,0 & 100,0 & 100,0 & 55,0 & 87,0 & 100,0 & 78,0 & 100,0 & 100,0 \\
\hline CB 146 & 2,0 & 100,0 & 100,0 & 60,0 & 91,4 & 90,0 & 87,0 & 92,6 & 100,0 \\
\hline
\end{tabular}


Tabela 2. Porcentagem de mortalidade acumulada (corrigida e confirmada) de Tetranychus urticae e porcentagem de ácaros mortos contendo cristais, pela inoculação com 45 isolados dos fungos entomopatogênicos (Continuação)

\begin{tabular}{|c|c|c|c|c|c|c|c|c|c|}
\hline \multirow{3}{*}{ Isolados } & \multicolumn{9}{|c|}{ Dias após a Inoculação (D.A.I.) } \\
\hline & \multicolumn{3}{|c|}{3 D.A.I. } & \multicolumn{3}{|c|}{4 D.A.I. } & \multicolumn{3}{|c|}{5 D.A.I. } \\
\hline & Corrig ${ }^{1}$ & Conf $^{2}$ & Cristais & Corrig & Conf & Cristais & Corrig & Conf & Cristais \\
\hline CB 147 & 29,0 & 82,7 & 80,0 & 48,4 & 86,4 & 100,0 & 57,6 & 90,0 & 88,9 \\
\hline CB 149 & 36,0 & 75,0 & 100,0 & 55,8 & 86,4 & 100,0 & 78,3 & 100,0 & 100,0 \\
\hline CB 150 & 1,0 & 100,0 & 100,0 & 19,2 & 100,0 & 100,0 & 60,4 & 91,4 & 90,0 \\
\hline CB 154 & 3,0 & 100,0 & 100,0 & 57,0 & 81,5 & 100,0 & 82,0 & 92,0 & 100,0 \\
\hline CB 157 & 8,0 & 100,0 & 100,0 & 76,0 & 80,9 & 100,0 & 93,0 & 94,1 & 90,0 \\
\hline CB 161 & 6,0 & 100,0 & 100,0 & 64,0 & 100,0 & 100,0 & 88,0 & 95,8 & 90,0 \\
\hline CB 164 & 7,1 & 75,0 & 83,3 & 43,2 & 71,4 & 100,0 & 65,5 & 66,7 & 90,0 \\
\hline CB 165 & 6,0 & 100,0 & 100,0 & 38,4 & 97,3 & 100,0 & 66,7 & 89,3 & 100,0 \\
\hline CB 166 & 11,0 & 90,9 & 100,0 & 73,0 & 91,9 & 100,0 & 89,0 & 93,7 & 100,0 \\
\hline CB 345 & 36,4 & 94,7 & 100,0 & 64,5 & 100,0 & 100,0 & 88,6 & 100,0 & 100,0 \\
\hline CB 347 & 30,3 & 100,0 & 100,0 & 62,4 & 100,0 & 100,0 & 82,9 & 100,0 & 100,0 \\
\hline CB 348 & 24,1 & 96,1 & 100,0 & 60,2 & 100,0 & 100,0 & 90,9 & 100,0 & 100,0 \\
\hline 353 & 14,9 & 100,0 & 100,0 & 41,9 & 96,5 & 100,0 & 72,6 & 96,6 & 100,0 \\
\hline 1037 & 14,7 & 100,0 & 100,0 & 55,4 & 97,5 & 100,0 & 85,1 & 100,0 & 100,0 \\
\hline 1205 & 1,5 & 0,0 & 0,0 & 0,0 & 0,0 & 0,0 & 2,9 & 22,2 & 0,0 \\
\hline 1216 & 1,0 & 0,0 & 0,0 & 1,0 & 25,0 & 0,0 & 1,0 & 0,0 & 0,0 \\
\hline 1247 & 11,0 & 100,0 & 100,0 & 61,2 & 100,0 & 100,0 & 94,8 & 97,0 & 100,0 \\
\hline 1260 & 13,0 & 100,0 & 100,0 & 53,1 & 97,6 & 100,0 & 78,4 & 96,0 & 100,0 \\
\hline 1282 & 24,0 & 95,8 & 0,0 & 55,1 & 100,0 & 0,0 & 73,2 & 88,9 & 0,0 \\
\hline 1286 & 16,8 & 100,0 & 90,0 & 77,2 & 98,3 & 100,0 & 93,1 & 100,0 & 100,0 \\
\hline 1294 & 1,1 & 83,3 & 100,0 & 17,4 & 94,4 & 100,0 & 44,8 & 89,3 & 100,0 \\
\hline
\end{tabular}

${ }^{1}$ Corrig = Mortalidade corrigida por Abbott (1925)

${ }^{2}$ Conf = Mortalidade confirmada 

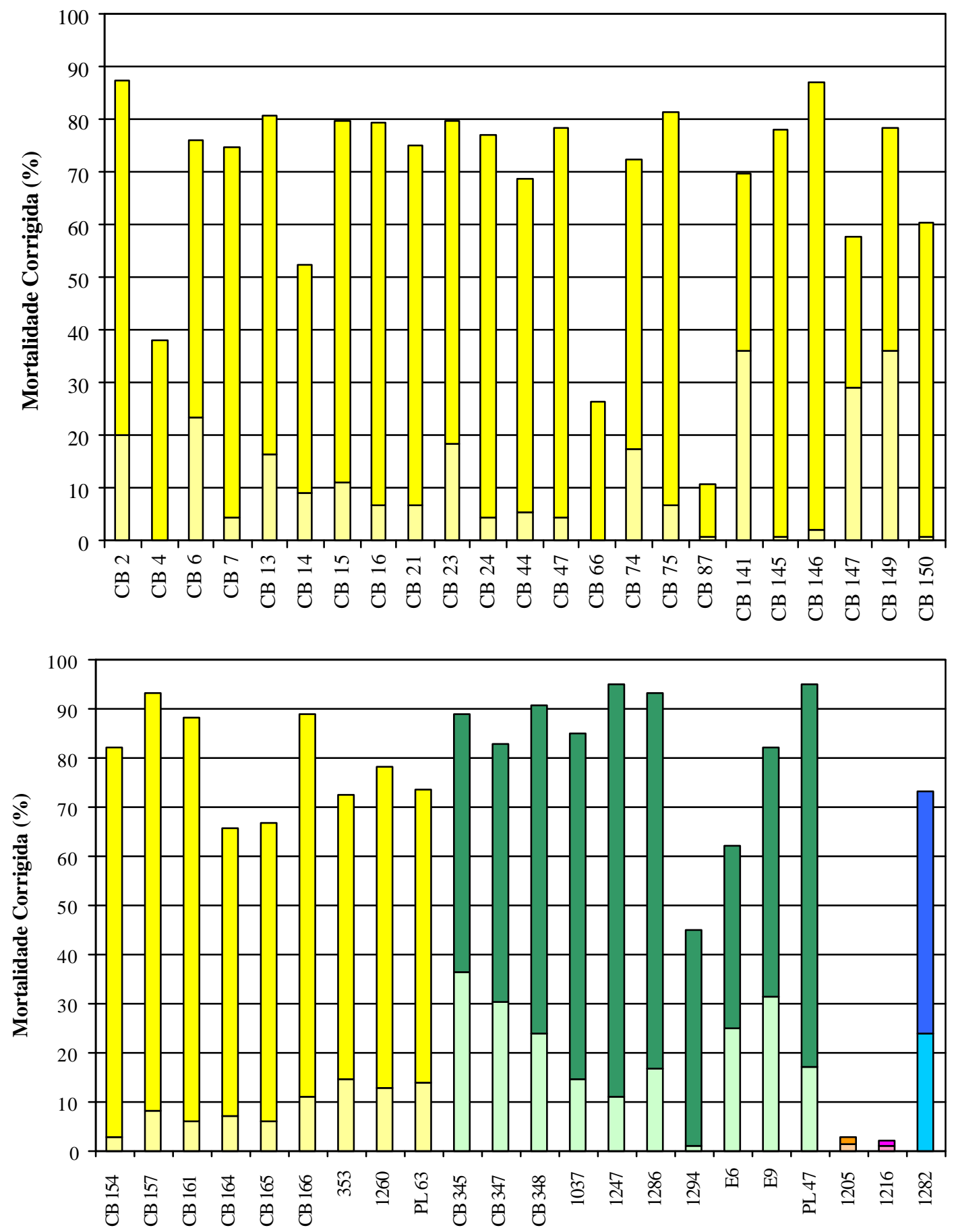

B. bassiana $\square$ M. anisopliae $\square$ P. farinosus $\square$ A. aleyrodis $\square$ Hirsutella sp.

Figura 1 - Porcentagem de mortalidade acumulada corrigida de Tetranychus urticae, aos 3 e 5 dias após a inoculação com conídios dos 45 isolados de fungos entomopatogênicos. Cor clara ( $\left.3^{\underline{0}} \mathrm{dia}\right)$; Cor escura $\left(5^{\underline{0}} \mathrm{dia}\right)$. 
O comportamento médio dos isolados de B. bassiana, M. anisopliae e Hirsutella sp. foram muito semelhantes para a porcentagem de mortalidade corrigida e confirmada (Tabela 2). Ao terceiro dia, a mortalidade média corrigida foi inferior a $24 \%$, ao quarto dia entre 50 e $60 \%$ e ao quinto dia entre 70 e $80 \%$. Os valores médios da mortalidade confirmada entre o terceiro e quinto dia foram sempre superiores a $80 \%$, comprovando que os ácaros mortos, em quase sua totalidade, tiveram como causa de sua morte a infecção pelo entomopatógeno. $\mathrm{O}$ fato de alguns ácaros não apresentarem a esporulação do entomopatógeno não descarta totalmente a possibilidade de terem sido mortos pelo inimigo natural. Em alguns casos, o álcool utilizado na desinfestação externa pode ter inviabilizado o fungo após sua entrada para o interior do cadáver por eventuais fissuras no tegumento, provocadas pelo pincel durante a transferência destes cadáveres para à câmara úmida. A ação rápida de bactérias decompositoras no cadáver pode também impedir que o fungo esporule sobre o mesmo.

Houve variações entre os isolados dos fungos B. bassiana e $M$. anisopliae quanto a porcentagem de mortalidade corrigida em todos os dias de avaliação. Grandes variações ocorreram ao terceiro dia após a inoculação, com valores entre 1 e 36\%. Apenas dois isolados de B. bassiana não apresentaram valores de mortalidade (CB 4 e CB 66) neste dia de avaliação. Estes dois isolados juntamente com CB 87 apresentaram valores inferiores a $40 \%$ decorridos cinco dias da inoculação, os menores entre todos os isolados deste entomopatógeno.

Considerando a mortalidade corrigida ao quinto dia para B. bassiana, 19 isolados (59\%) apresentaram valores entre 60 a 80\%, enquanto que cinco (16\%) e oito isolados (25\%) tiveram valores inferiores e superiores a esta faixa de mortalidade, respectivamente. Os oito isolados com maiores valores de mortalidade foram: CB 2, CB 13, CB 75, CB 146, CB 154, CB 157, CB 161 e CB 166. Quanto a M. anisopliae, a grande maioria dos isolados $(80 \%)$ apresentou valores superiores a $80 \%$, destes, apenas 4 isolados (CB 348, 1247, 1286 e PL47) apresentaram valores superiores a 90\% a este dia de avaliação. O isolado 1282 de Hirsutella sp. apresentou mortalidade de 73\%, um pouco inferior aos melhores isolados de B. bassiana e $M$. anisopliae, contudo, esse resultado é referente a concentração de $1,7 \times 10^{7}$ conídios/mL, concentração cerca de 3 vezes menor 
do que a utilizada para todos as demais espécies de fungos. $\mathrm{O}$ reduzido rendimento na produção de conídios em meio de cultura sólido impediu que Hirsutella sp. fosse avaliada na mesma concentração dos demais fungos.

Não houve relação aparente entre os valores de mortalidade corrigida ao terceiro dia e os observados ao quinto dia. Alguns isolados como o CB 146 e CB 154 (B. bassiana) apresentaram valores de mortalidade reduzidos ao terceiro dia $(<3 \%)$ e elevados ao quinto dia (> 80\%). O inverso também foi observado, como por exemplo para o CB 141 e 147 (B. bassiana) que apresentaram valores superiores a 29\% ao terceiro dia e inferiores a $70 \%$ ao quinto dia.

Os valores elevados de mortalidade ao terceiro dia indicam uma ação rápida do patógeno sobre a praga, porém a utilização deste fator como parâmetro de seleção de isolados requer algumas considerações. Para insetos capazes de transmitir viroses e com grande capacidade de dispersão, como os tripes e moscas-brancas, torna-se necessário seu controle de forma imediata como meio de impedir o alastramento da doença na cultura. Embora T. urticae não seja um transmissor de viroses, sua ocorrência em culturas de ciclo curto e que apresentam reduzido nível de dano econômico, como as culturas ornamentais e olerícolas, exige o seu rápido controle.

A rapidez com que o patógeno mata seu hospedeiro é uma característica desejável para o controle de muitas pragas agrícolas, contudo, não deve ser considerada como única. É imprescindível também que o isolado seja capaz de proporcionar elevada mortalidade final, exigindo desta maneira pulverizações menos freqüentes e possibilitando reduzir os custos de controle das pragas. Para insetos sociais como cupins e formigas o efeito rápido do inseticida (químico ou biológico) não é uma característica desejada, pois estes insetos apresentam comportamento de proteção da colônia que envolvem o isolamento dos indivíduos doentes do restante da colônia, impedindo desta forma o transmissão e/ou disseminação do inseticida entre os indivíduos sadios. Este é o princípio do controle de Atta spp. (Hymenoptera: Formicidae) com iscas tóxicas e a estratégia que se utiliza para o controle do cupim Heterotermes tenuis (Isoptera: Rhinotermitidae) com B. bassiana (Gallo et al., 1988; Almeida \& Alves, 1996). 
Comparar os produtos químicos com entomopatógenos baseando-se exclusivamente na mortalidade pode inferir em erros de avaliação em termos de controle. Ácaros infectados que ainda permanecem vivos normalmente apresentam suas funções biológicas afetadas, como reprodução e alimentação, proporcionando ao produtor os mesmos benefícios do produto químico. Porém age contra os entomopatógenos a própria expectativa do produtor que deseja que o produto tenha efeito imediato sobre a praga, no conhecido binômio "aplicou-matou".

Com exceção de Hirsutella sp. as demais espécies de fungos testados não são observadas atacando ácaros fitófagos em condições naturais, o que de certa forma explica o baixo desempenho obtido por A. aleyrodis, como referido anteriormente. Com relação à B. bassiana e $M$. anisopliae embora não sejam observadas causando epizootias em ácaros fitófagos, o que facilitaria sua constatação em condições naturais, estes são referidos como entomopatógenos de amplo espectro hospedeiro ou pouco específicos, causando doença em espécies de insetos e ácaros de diversas ordens e famílias. Somente para o gênero Beauveria são conhecidas, pelo menos, 200 espécies de insetos e ácaros suscetíveis (Alves, 1998a). Esta característica tem contribuído para que estas espécies sejam muito estudadas em vista ao controle de pragas em todo mundo. Ao contrário de $B$. bassiana e M. anisopliae, os fungos da Ordem Entomophthorales apresentam, muitas vezes, especificidade hospedeira (Delalibera Júnior et al., 1997). Esta característica confere aos fungos Entomophthorales uma grande segurança em termos de efeito sobre organismos não alvos, muito importante quando se deseja introduzir o inimigo natural em áreas onde não ocorre naturalmente (controle biológico clássico).

Embora muitos isolados de M. anisopliae e B. bassiana tenham se mostrado semelhantes quanto à mortalidade ao quinto dia após a inoculação, pode-se, por efeito prático, selecionar cinco isolados de cada espécie (B. bassiana: CB 2, CB 146, CB 157, CB 161 e CB 166; M. anisopliae: CB 345, CB 348, 1247, 1286 e PL47) promissores para seu desenvolvimento como constituintes de formulações micoacaricidas. Este trabalho de seleção vêm a complementar ao desenvolvido por Tamai (1998) na busca por isolados geneticamente superiores para o controle de pragas, pois esta etapa deve ser parte constituinte e permanente para a melhoria dos produtos microbianos oferecidos aos 
consumidores. Atualmente o isolado PL63 selecionado por Tamai (1998) encontra-se em fase final de registro nos órgãos federais competentes, e seu desempenho tem se mostrado muito bom, em se tratando de um produto biológico desenvolvido com poucos recursos financeiros, para o controle de T. urticae na cultura do mamão no Estado do Espirito Santo. Contudo, este isolado poderá vir a ser substituído por algum dos selecionados neste trabalho como parte constituinte dos esforços no sentido de aumentar a confiabilidade dos produtos biológicos como peça constituinte de programas de manejo integrado de pragas.

Observou-se a presença de cristais de cálcio no interior dos ácaros mortos (Figuras 2A e 2B) para todos os isolados de B. bassiana (32 isolados) e M. anisopliae (10 isolados) avaliados, com ocorrências média quase sempre superior a $80 \%$ dos ácaros mortos observados. Para os fungos A. aleyrodis, Hirsutella sp. e P. farinosus não foi constatada a presença dos cristais em nenhum ácaro morto. Os fatores ligados a formação destes cristais nos ácaros ainda não são conhecidos, mas sua presença no interior dos ácaros mortos por B. bassiana e M. anisopliae sugerem semelhanças entre estes fungos no processo de colonização dos organismos hospedeiros.

Estes cristais são de tamanho e forma variadas, alguns alongados e outros apresentando geometria bipiramidal (Figuras 2A e 2B, respectivamente). Sua constatação nos ácaros foi feita a partir do terceiro dia após a inoculação, correspondendo ao início do período de colonização do hospedeiro pelo patógeno. Foram observados predominantemente na região posterior do corpo dos ácaros. Pelo tamanho e localização, sua presença deve interferir nas atividades normais de funcionamento dos órgãos do hospedeiro.

A formação de cristais é conhecida quase exclusivamente para ácaros infectados por vírus, contudo, ainda não havia sido observada para fungos. A presença de cristais é comum em Panonychus citri infectados por um vírus não-incluso em pomares cítricos nos Estados Unidos. De acordo com Beavers \& Reed (1972) a infecção pelo vírus pode ser determinada montando-se os ácaros em meio Hoyer e examinando-os em microscópio de luz polarizada para a presença ou ausência de cristais birefringentes no interior dos ácaros. A observação dos cristais era de fundamental importância para a 
comprovação da infecção pelo patógeno, pois as partículas virais são muito pequenas, de difícil visualização. Estes cristais foram observada por Tashiro \& Beavers (1966) em $77 \%$ dos ácaros mortos pelo patógeno e 54\% dos ácaros vivos infectados, durante uma epizootia. Inclusões birefringentes dentro do mesêntero de Panonychus ulmi foram observadas por Bird (1967), quando os ácaros encontravam-se infectados por um outro vírus não-incluso. $\mathrm{Na}$ Europa existe a suspeitas de que um entomopatógeno seja o responsável pela formação de cristais na forma de halteres na região posterior de Phytoseiulus persimilis, capaz de comprometer sua reprodução, predação e longevidade (Bjornson et al., 2000).

Nos estudos de infecção de Phyllocoptruta oleivora (McCoy \& Couch, 1978; Sosa-Gómez \& Nasca, 1983) e T. urticae (Gerson et al., 1979) por H. thompsonii, não foram feitas pelos pesquisadores qualquer referência a possível presença de cristais nos ácaros infectados, mesmo quando descreveram com detalhes o processo de colonização dos ácaros por este fungo. O mesmo aconteceu para Neozygites floridana infectando os ácaro tetraniquídeos Eutetranychus banksi (Selhime \& Muma, 1966) e T. urticae (Carner, 1976). Contudo, recentemente foi observado a presença de pequenos cristais no interior de adultos de P. oleivora infectados por B. bassiana (M.A. Tamai, 2000. Comunicação pessoal) e sobre o tegumento de Brevipalpus phoenicis infectado pelo fungo $V$. lecanii (M.R. Tanzini, 2000. Comunicação pessoal).

Os fatores que envolvem a formação de cristais em ácaros ainda não é bem conhecida, contudo, no estudo de Norton \& Behan-Pelletier (1991) são propostas algumas hipóteses. Deposições de carbonato de cálcio e oxalato de cálcio foram observados pelos autores em diversos pontos do tegumento de ácaros de solo (Acari: Oribatida), conferindo dureza ao tegumento, e desta forma, contribuindo para a sua defesa contra o ataque de seus predadores. A origem destes cristais foi discutida, e sugerem, com base na literatura, que estes cristais são formados pela reação entre o ácido oxálico, produzido durante o metabolismo de fungos decompositores, com o cálcio presente na solução do solo. Para estes fungos, o ácido oxálico atua no processo nãoenzimático de decomposição vegetal, sendo os cristais de oxalato de cálcio precipitados na superfície de suas hifas. Estas deposições de cálcio presentes sobre o tegumento dos 
ácaros oribatídeos derivam dos cristais originalmente precipitados pelos fungos no solo, estes fungos por sua vez, servem de alimento para estes ácaros.

Considerando que os fungos $B$. bassiana e $M$. anisopliae são também habitantes do solo, onde vivem dos componentes orgânicos deste ambiente, é provável que a origem dos cristais observados em T. urticae seja a reação entre o ácido oxálico produzido pelo metabolismo destes fungos, com o cálcio presente na hemolinfa do ácaro. Este tipo de cristal também foi observado por Amaral \& Alves (1979) sobre o tegumento e na hemolinfa de Bombyx mori infectados por B. bassiana. Neste caso, a formação dos cristais pode ter ocorrido externamente pela reação do ácido oxálico com a cálcio polvilhado sobre os insetos, como prática usual dos produtores para prevenir a infecção dos insetos por este entomopatógeno. Moino Júnior (1998) observou a formação de reduzido número de cristais em locais de intenso crescimento micelial de B. bassiana sobre o tegumento do cupim Heterotermes tenuis.

Estudos detalhados são necessários para que possa ser elucidado o fenômeno envolvido na formação dos cristais de cálcio durante a colonização de insetos e ácaros por B. bassiana e $M$. anisopliae, bem como no papel destes cristais no ciclo das relações entre patógeno-hospedeiro. 

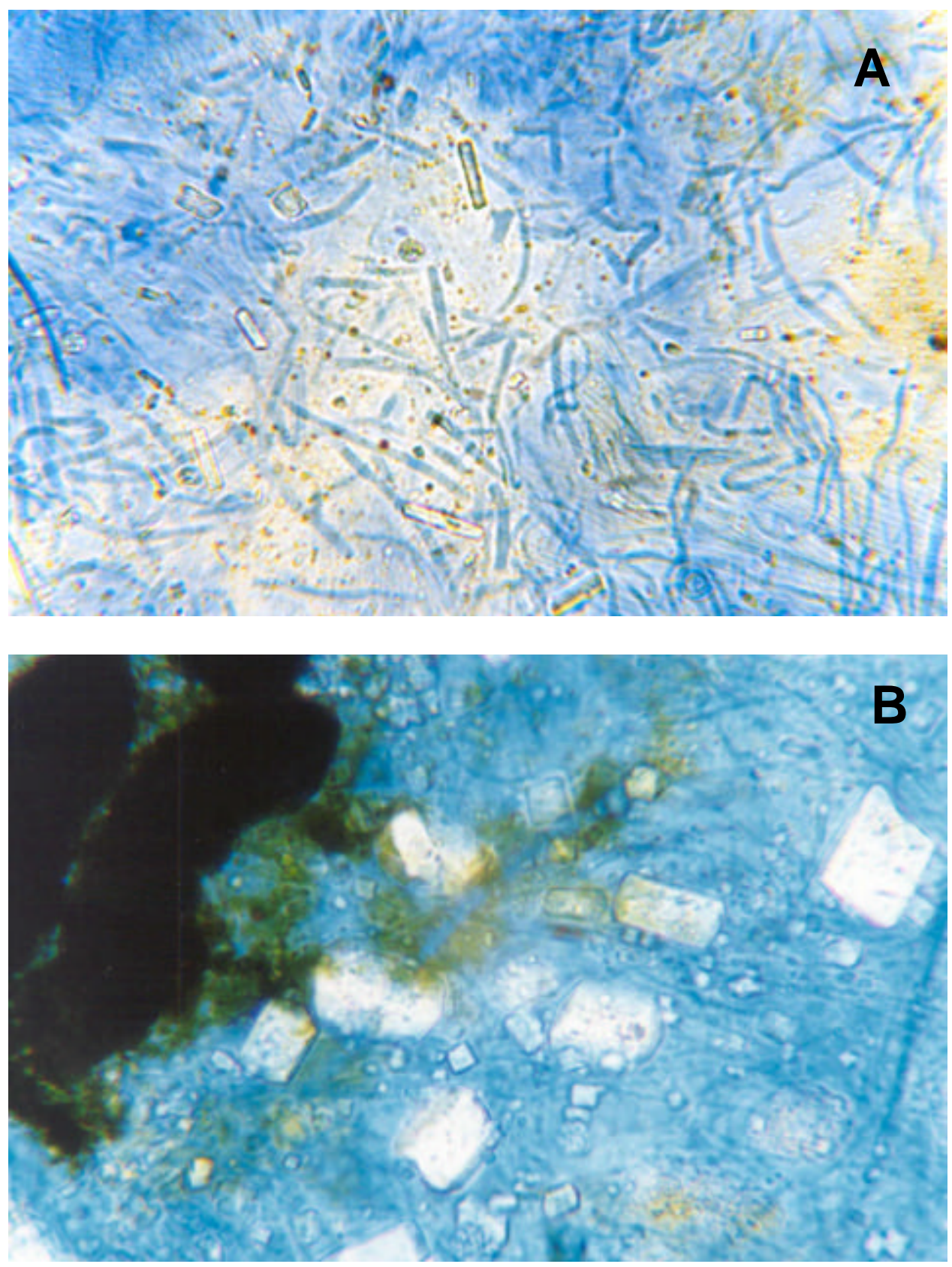

Figura 2 - Cristais de cálcio formados no interior de Tetranychus urticae pela colonização do ácaro por Beauveria bassiana. Cristais de formato alongado (A) e bipiramidal (B). 


\subsection{Conclusões}

- A. aleyrodis e $P$. farinosus apresentam reduzida patogenicidade a $T$. urticae

- os valores médios de mortalidade corrigida e confirmada de T. urticae causados pelos isolados de B. bassiana, M. anisopliae e Hirsutella sp. são semelhantes

- os isolados CB 2, CB 146, CB 157, CB 161 e CB 166 de B. bassiana e os isolados CB 345, CB 348, 1247, 1286 e PL47 de M. anisopliae são altamente patogênicos e promissores para o controle microbiano de T. urticae

- todos os isolados de B. bassiana e M. anisopliae produzem cristais de cálcio no interior do corpo dos ácaros infectados. 


\section{AVALIAÇÃo da PATOGENiCIDAde DE CONÍDIO, BLASTÓSPORO E CÉLULA DE LEVEDURA DE Beauveria bassiana PARA Tetranychus urticae}

\section{Resumo}

Avaliou-se a virulência das estruturas infectivas conídio aéreo, blastósporo e célula de levedura de cinco isolados de Beauveria bassiana ao ácaro Tetranychus urticae. Os isolados foram pulverizados sobre fêmeas adultas do ácaro nas concentrações de $3,2 \times 10^{5} ; 1 \times 10^{6} ; 3,2 \times 10^{6} ; 1 \times 10^{7} ; 3,2 \times 10^{7} ; 1 \times 10^{8} ; 3,2 \times 10^{8}$ destas estruturas $/ \mathrm{mL}$, e mantidos a $25 \pm 1{ }^{\circ} \mathrm{C}, 98 \%$ de UR e 12 horas de fotofase, durante cinco dias. Todas as combinações entre estruturas infectivas e isolados causaram mortalidade em T. urticae, comprovando-se a patogenicidade de blastósporo e célula de levedura de B. bassiana a esta praga. Foram observadas diferenças significativas $(\mathrm{P} \geq 0,05)$ para $\mathrm{CL}_{50}$ e nos coeficientes angulares entre

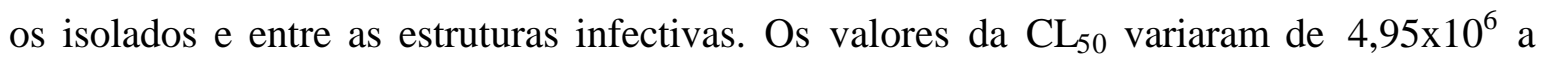
$8,21 \times 10^{7}$ estruturas infectivas/mL, e os coeficientes angulares de 0,684 a 1,288. Os resultados da análise conjunta dos cinco isolados em cada estrutura infectiva mostraram que não houve diferença significativa entre célula de levedura e as demais estruturas infectivas para os dois parâmetros avaliados. Contudo, houve diferenças significativas para a $\mathrm{CL}_{50}$ entre as estruturas infectivas em um mesmo isolado de fungo. Diferenças significativas entre conídio e célula de levedura foram observadas para dois isolados, e entre célula de levedura e blastósporo para apenas um isolado. Nestes dois casos os valores da $\mathrm{CL}_{50}$ para célula de levedura foram inferiores aos demais. Para todos os isolados não se constatou diferenças na infectividade de conídio e blastósporo. 
Palavras-chave: Tetranychus urticae, Beauveria bassiana, conídio, blastósporo, célula de levedura, controle biológico.

\section{PATHOGENICITY OF CONIDIA, BLASTOSPORES AND YEASTLIKE CELLS OF Beauveria bassiana AGAINST Tetranychus urticae}

\section{Summary}

The virulences of three infective structures, conidia, blastospores and yeastlike cells, of five Beauveria bassiana isolates were evaluated against the mite Tetranychus urticae. The isolates were sprayed on mite adult females at concentrations of $3.2 \times 10^{5} ; 1 \times 10^{6} ; 3.2 \times 10^{6} ; 1 \times 10^{7} ; 3.2 \times 10^{7} ; 1 \times 10^{8} ; 3.2 \times 10^{8}$ cells $/ \mathrm{mL}$, and maintained at $25 \pm 1^{\circ} \mathrm{C}, 98 \% \mathrm{RH}$ and $12 \mathrm{~h}$ photofase for 5 days. All infective structures of all isolates caused $T$. urticae mortality, confirming that $B$. bassiana blastospores and yeastlike cells are infective against this pest. Significant differences ( $P$ 0.05) were observed among the $\mathrm{LC}_{50}$ 's and slopes of dose-mortality lines for the different isolates and infective structures. $\mathrm{LC}_{50}$ values ranged from $4.95 \times 10^{6}$ to $8.21 \times 10^{7}$ cells $/ \mathrm{mL}$, and the slopes of dose-mortality lines from 0.684 to 1.288 . Factorial analysis showed no difference between the yeastlike cells and the other infective structures in the two tested variables. However, there were significant differences among the $\mathrm{LC}_{50}$ 's with different infective structures within the same isolate. Significant differences between conidia and yeastlike cells were observed for two isolates, whereas differences between yeastlike cells and blastospores occurred only with one isolate. In these cases, the $\mathrm{LC}_{50}$ 's for yeastlike cells were always lower than those for other infective structures. No differences were observed between conidia and blastospores for all isolates.

Keywords: Tetranychus urticae, Beauveria bassiana, conidia, blastospores, yeastlike cells, biological control. 


\subsection{Introdução}

Os fungos entomopatogênicos são os principais agentes etiológicos de doenças em insetos e ácaros pragas das plantas cultivadas, com mais de 700 espécies descritas em todo mundo. Contudo, apenas uma dezena tem sido correntemente estudada e desenvolvida para uso como produtos microbianos, dentre as quais se destacam Beauveria bassiana, Metarhizium anisopliae, Verticillium lecanii e Paecilomyces fumosoroseus, com diversos produtos comerciais disponíveis em países de todos os continentes (Hajek \& St. Leger, 1994; Alves et al., 1998a; Shah \& Goettel, 1999). As facilidades de produção em escala industrial, formulação e aplicação são algumas das características que fazem destas espécies, os fungos mais utilizados para o controle de pragas.

Espécies como B. bassiana, $M$. anisopliae e $V$. lecanii podem ser desenvolvidas como produtos microbianos usando-se algum(s) dos diferentes estágios infectivos de seu ciclo biológico como conídios (aéreo e submerso), micélio e blastósporo, agindo como seu estágio mais infectivo ou possibilitando a produção desse estágio no campo. Com exceção do conídio aéreo, as demais estruturas infectivas são produzidas de forma submersa, utilizando-se meios de cultura líquidos. Desse modo, torna-se possível sua produção (meios líquidos, sólidos e semi-sólidos) e formulação (pós, grânulos, granulados, micélio seco, óleos emulsionáveis, etc.) de forma adequada à bioecologia das pragas-alvo e às características da cultura e do agroecossistema em que são utilizados (Batista Filho et al., 1998). Juntamente com estudos referentes aos custos de produção, rendimento industrial, estabilidade e virulência das estruturas infectivas determinam o sucesso destes produtos microbianos no controle de pragas.

De um modo geral, B. bassiana tem sido formulada utilizando-se conídios (aéreos) aplicados nas formas de pós ou suspensões aquosas de conídios, com os mesmos equipamentos empregados para os produtos químicos ou com pequenas adaptações. Devido à simplicidade da produção deste tipo de conídio, esse método tem sido muito utilizado em vários países, inclusive o Brasil. A utilização de blastósporo e conídio produzidos em meios líquidos tem a vantagem de se obter grandes quantidades 
destas estruturas em tempo e espaços físicos reduzidos (Lane et al., 1991a), contudo, ainda existem grandes desafios a serem superados quanto à sua estabilidade e formulação. Os avanços nas pesquisas verificados com essas duas estruturas têm servido de estimulo para estudos que avaliem seu potencial como componentes de formulações microbianas.

O estudo comparativo da patogenicidade das diferentes estruturas infectivas de $B$. bassiana pode contribuir para o desenvolvimento de formulações microbianas mais eficientes e econômicas para sua utilização em programas de manejo integrado de pragas, além de permitir um melhor conhecimento da fisiologia e morfologia deste microrganismo. Desse modo, os objetivos desta pesquisa foram o de comprovar a patogenicidade de blastósporo e célula de levedura produzidas por B. bassiana a $T$. urticae e comparar sua eficiência com à proporcionada pelo conídio produzido em meio de cultura sólido. As células de levedura foram recentemente observadas para $B$. bassiana, sendo esta pesquisa uma das primeiras que comprovam sua patogenicidade para pragas agrícolas.

\subsection{Material e Métodos}

Fêmeas adultas recém emergidas de T. urticae foram transferidas de uma criação estoque em plantas de feijão-de-porco, Canavalia ensiformis (Dicotiledonea: Fabaceae), para placas de polietireno de 4,0 cm de diâmetro, contendo cada placa um disco de folha de $C$. ensiformis de 2,5 cm de diâmetro sobre uma espuma de polietileno umedecida. Cada placa recebeu inicialmente 15 fêmeas do ácaro, sendo que após trinta minutos foram retirados os ácaros mortos e o excedente, de forma a deixar apenas 10 ácaros/placa. Em seguida, os ácaros foram pulverizados com os tratamentos em Torre de Potter, utilizando-se volume de $2 \mathrm{~mL}$ de suspensão e pressão de 15 libras/pol ${ }^{2}$. Cada tratamento consistiu de 10 placas, sendo cada placa uma repetição. Após a pulverização, as placas foram mantidas em condição ambiente por 15 minutos para a evaporação da porção líquida da suspensão. Posteriormente, foram acondicionadas dentro de caixa 
plástica transparente (34 cm de comprimento x $22 \mathrm{~cm}$ de largura e $12 \mathrm{~cm}$ de altura) (Figuras 3A e 3B), que foi mantida fechada dentro de câmara B.O.D., sob a temperatura de $25 \pm 1{ }^{\circ} \mathrm{C}, 98 \%$ de UR e 12 horas de fotofase. Diariamente a caixa foi mantida aberta por 30 minutos para a renovação do ar com o ambiente.

Os tratamentos avaliados foram representados por três estruturas infectivas do ciclo-de-vida de B. bassiana (conídio aéreo, célula de levedura e blastósporo) produzidas por cinco isolados deste fungo. Os isolados foram pulverizados sobre os ácaros nas concentrações de $3,2 \times 10^{5} ; 1 \times 10^{6} ; 3,2 \times 10^{6} ; 1 \times 10^{7} ; 3,2 \times 10^{7} ; 1 \times 10^{8} ; 3,2 \times 10^{8}$ destas estruturas/mL. Estas concentrações correspondem aos valores em logconcentração de 5,5 a 8,5 em progressão aritmética de 0,5. O tratamento testemunha recebeu apenas água destilada estéril + espalhante adesivo (Tween $80^{\circledR}-0,2 \mathrm{~mL} / \mathrm{L}$ ). Foi utilizado um código composto de letras e números para a identificação dos tratamentos nas tabelas de resultados, sendo que as duas letras iniciais fazem referencias à sua estrutura infectiva, neste LV (levedura), BL (blastósporo) e CN (conídio); as demais letras e/ou números referem-se à identificação do isolado de B. bassiana .

Os isolados de B. bassiana testados (Tabela 3) encontram-se armazenados no Banco de Patógenos do Laboratório de Patologia e Controle Microbiano de Insetos do Departamento de Entomologia, Fitopatologia e Zoologia Agrícola da ESALQ/USP, em freezer a $-12^{\circ} \mathrm{C}$ na forma de conídios puros.

Para os testes com conídios, estes foram produzidos em meio de cultura M.C. (meio completo) (Alves et al., 1998c) colocando-se amostras de conídios puros dos isolados em placa de Petri contendo o meio de cultura estéril. Estes foram espalhados por toda a placa com alça de Drigalsky e as placas mantidas durante 7 dias em câmara B.O.D. sob a temperatura de $26 \pm 0,5^{\circ} \mathrm{C}$ e 12 horas de fotofase para o crescimento e produção de conídios pelos isolados. Os conídios produzidos foram removidos da superfície do meio de cultura com auxílio de uma espátula de metal, para o preparo das suspensões em água destilada estéril mais espalhante adesivo (Tween $80^{\circledR}-0,2 \mathrm{~mL} / \mathrm{L}$ ).

A produção de blastósporos pelos isolados foi feita em béqueres de $250 \mathrm{~mL}$ contendo $50 \mathrm{~mL}$ de meio de cultura líquido M.C. (meio completo) sem ágar. Cada béquer foi inoculado com uma porção circular de 1,3 cm de diâmetro de uma cultura do 
fungo, retirada de placas de Petri dos isolados de B. bassiana após sete dias de incubação em meio de cultura M.C. (com ágar) sob a temperatura de $26 \pm 0,5^{\circ} \mathrm{C}$ e 12 horas de fotofase, contendo predominantemente conídios. Após a inoculação, os béqueres foram mantidos em uma incubadora com agitação à 220 a 240 rpm e temperatura de $25^{\circ} \mathrm{C}$, durante 48 horas para a produção dos blastósporos no meio de cultura. Após este período, o conteúdo dos béqueres foram reunidos em apenas um, e então centrifugado a $5000 \mathrm{rpm}$, durante 15 minutos, para a precipitação dos blastósporos. O sobrenadante, contendo apenas o meio de cultura, foi descartado e os blastósporos foram suspensos em água destilada estéril mais espalhante adesivo (Tween $\left.80^{\circledR}-0,2 \mathrm{~mL} / \mathrm{L}\right)$ para o preparo das suspensões.

As células de leveduras foram produzidas em placas de Petri contendo meio de cultura sólido Mac Conkey com cristal violeta (Sanofi Diagnostics Pasteur) (51,5 g do meio para $1000 \mathrm{~mL}$ de água). Este meio foi inicialmente desenvolvido para a detecção da bactéria Escherichia coli em amostras diversas, contudo, estudos recentes desenvolvidos no Laboratório de Patologia e Controle Microbiano de Insetos (ESALQ/USP) demonstraram que este meio de cultura é também seletivo para o isolamento de B. bassiana de biofertilizantes líquidos. As placas com o meio de cultura foram inoculadas com conídios puros dos isolados e incubadas em B.O.D. sob a temperatura de $26 \pm 0,5^{\circ} \mathrm{C}$ e 12 horas de fotofase durante 48 a 60 horas para a produção das células de levedura. A separação das células do meio de cultura foi feita raspando-se a superfície do meio de cultura com uma espátula de metal. Em seguida, as suspensões foram preparadas adicionando-se as células de levedura em água destilada estéril mais espalhante adesivo. O ciclo de B. bassiana em meio Mac Conkey com a fase de levedura é apresentada na Figura 4 (Alves et al., 2002. Comunicação pessoal). 

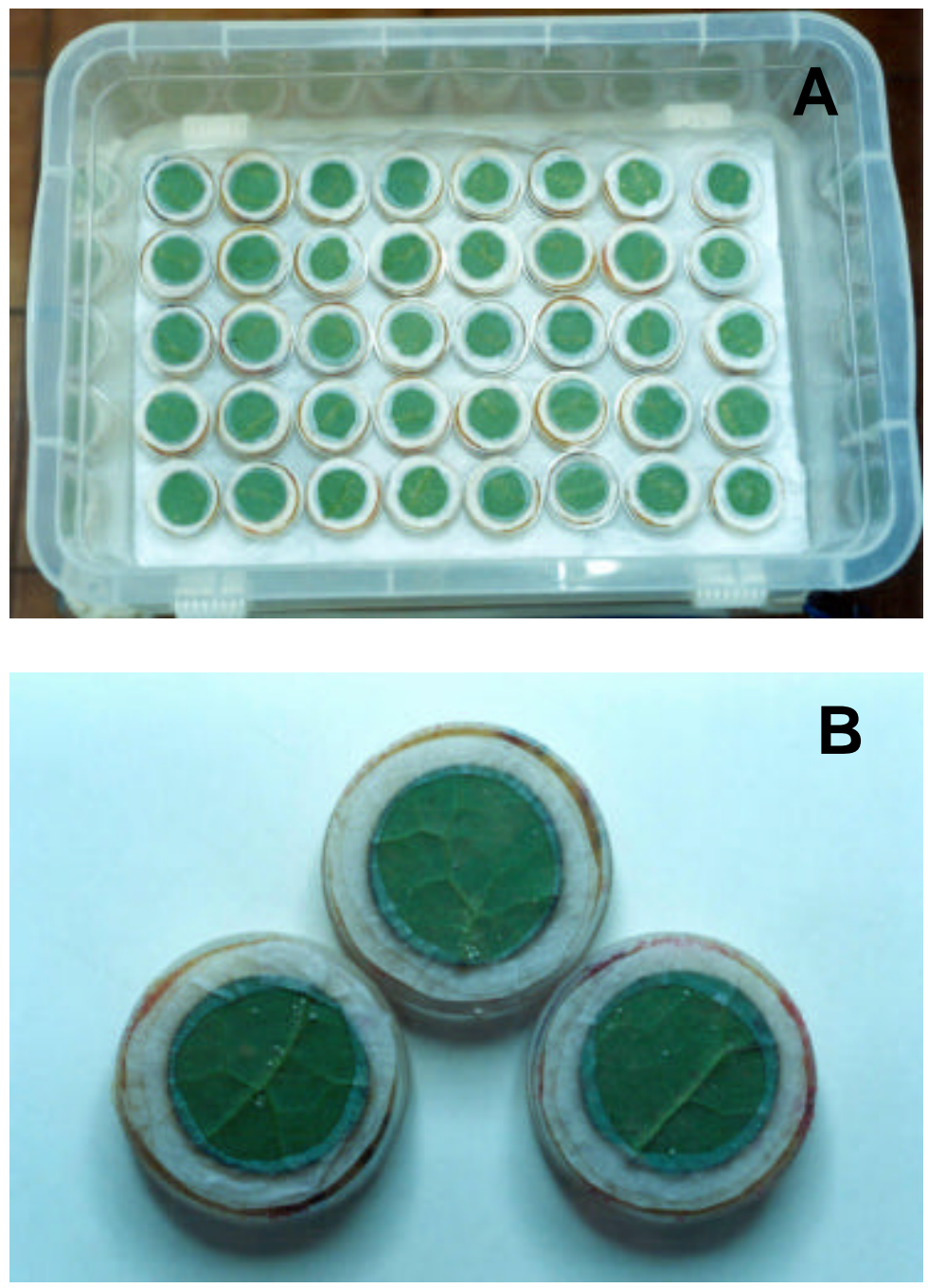

Figura 3 - Caixa plástica contendo discos de folha de Canavalia ensiformis infestadas com Tetranychus urticae (A); detalhe dos discos de folhas acondicionados nas placas de acrílico (B). 


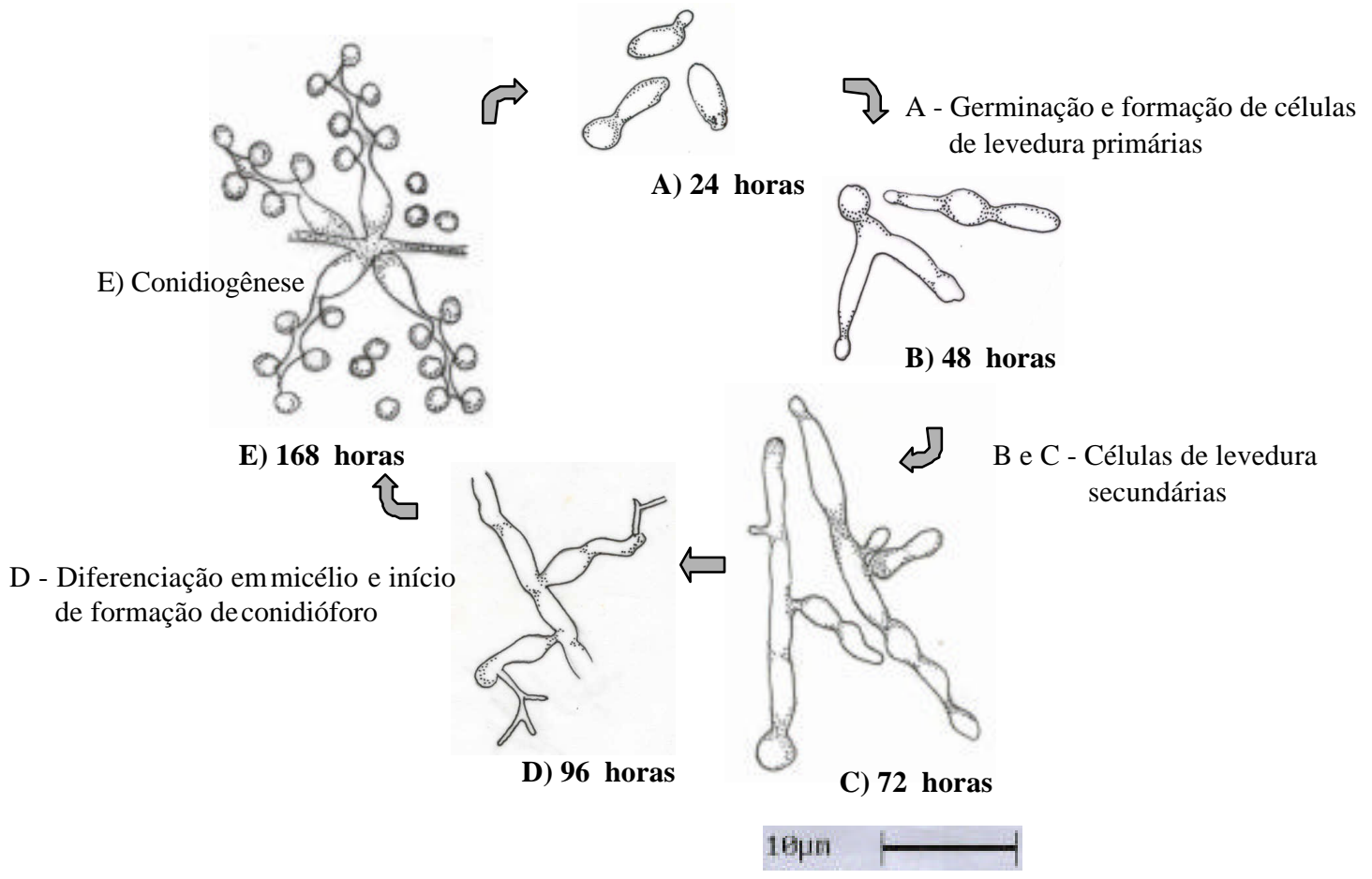

Figura 4 - Ciclo de Beauveria bassiana em meio de cultura MacConkey (Alves et al., 2002. Comunicação pessoal).

Tabela 3. Procedência e hospedeiro dos isolados de Beauveria bassiana utilizados nos bioensaios com Tetranychus urticae

\begin{tabular}{lll}
\hline Isolado & Procedência & Hospedeiro \\
\hline PL63 & Piracicaba-SP & Atta sp. (Hymenoptera: Formicidae) \\
307 & Araras-SP & Diatraea saccharalis (Lepidoptera: Crambidae) \\
457 & EMGOPA-GO & Euschistus heros (Hemiptera: Pentatomidae) \\
489 & Desconhecida & Hemileucidae (Lepidoptera) \\
494 & Piracicaba-SP & Dorcadocerus barbatus (Coleoptera: Cerambycidae) \\
\hline
\end{tabular}

Foi feito uma única avaliação aos cinco dias após a inoculação do patógeno, anotando-se o número de ácaros mortos em cada placa. Os valores de mortalidade foram 
analisados pelo programa Polo-PC (LeOra Software, 1987) para a determinação da concentração letal média (CL50) de cada combinação isolado/estrutura de infeção.

\subsection{Resultados e Discussão}

Todas as combinações entre estruturas infectivas e isolados causaram mortalidade em fêmeas adultas de T. urticae, sendo deste modo comprovado pela primeira vez a patogenicidade de blastósporo e célula de levedura de B. bassiana ao ácaro. Independentemente da estrutura e do isolado utilizado, os sintomas e sinais da doença foram semelhantes quando observados ao quinto dia após a inoculação. Ácaros vivos e infectados pelo entomopatógeno geralmente apresentavam tremores nas pernas, movimentação reduzida e tegumento de coloração escurecida. Ácaros recém mortos, caracterizados por não terem sinais da extrusão do entomopatógeno, apresentaram, em muitos casos, com o corpo de coloração rósea. Esta coloração é conferida pelo acúmulo da substância antibiótica oosporina produzida pelo fungo, durante a fase de colonização do hospedeiro, com o objetivo de impedir que ocorra a desintegração dos tecidos do hospedeiro por microrganismos saprófitas, que deste modo poderia prejudicar o desenvolvimento normal do entomopatógeno (Alves, 1998a). Alguns ácaros mortos eram também observados murchos (desidratados) e apresentando coloração entre o marrom escuro e o preto. Contudo, a maioria dos ácaros mortos encontravam-se esbranquiçados, decorrente do crescimento micelial e conidiogênese do entomopatógeno sobre os cadáveres (Figura 5A). 

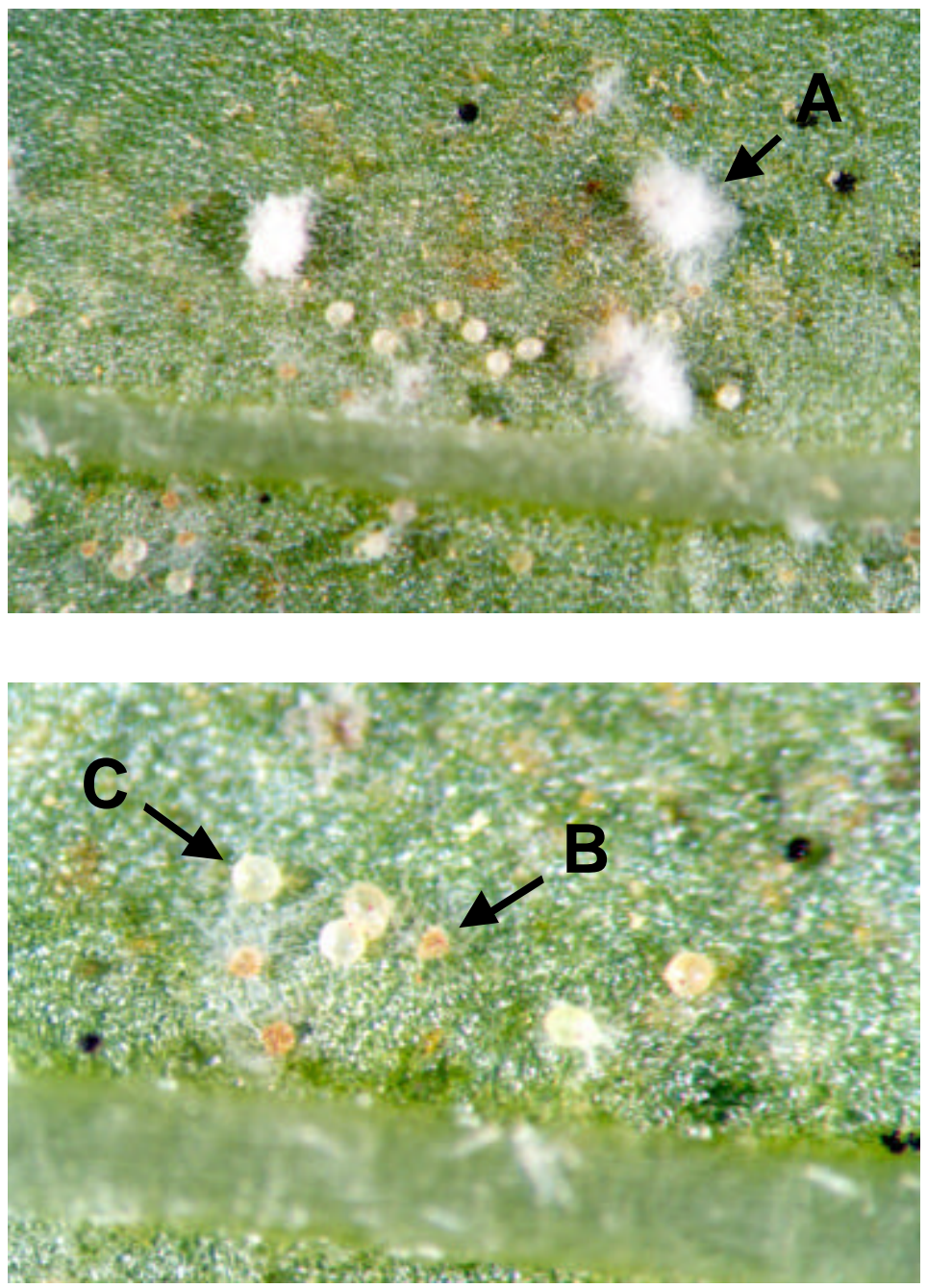

Figura 5 - Cadáveres de Tetranychus urticae apresentando esporulação de Beauveria bassiana (A); ovos de Tetranychus urticae com sintomas de infecção por Beauveria bassiana (B) e sem sintomas de infecção (C).

Ovos que se encontravam infectados pelo fungo apresentavam-se murchos e com coloração amarelo-alaranjado (Figura 5B), possuindo micélio e cristais em seu interior. Estes cristais também foram observados no interior dos ácaros mortos e são 
produzidos durante sua colonização pelo entomopatógeno. Ovos sem sintomas de infecção apresentavam coloração amarelo-claro (Figura 5C).

A análise da mortalidade de T. urticae pela inoculação das estruturas infectivas (conídio, blastósporo e célula de levedura) produzidas pelos isolados de B. bassiana (307, 457, 489, 494 e PL63) são apresentadas na Tabela 4. Foram observadas diferenças significativas $(\mathrm{P} \geq 0,05)$ para $\mathrm{CL}_{50}$ e coeficiente angular entre os isolados e entre as estruturas infectivas.

Os valores da $\mathrm{CL}_{50}$ variaram de $4,95 \times 10^{6}$ (LV307) a $8,21 \times 10^{7}$ estruturas infectivas/mL (BL489), com diferença entre eles de aproximadamente 16,6 vezes. Quanto ao coeficiente angular, os valores variaram entre 0,684 (LV489) e 1,288 (BL457) sendo de aproximadamente 1,9 vezes a diferença entre seus valores. Apenas quatro tratamentos $(26,7 \%)$ apresentaram $\mathrm{CL}_{50}$ inferiores a $1 \times 10^{7}$ estruturas infectivas/mL (LV307, LVPL63, LV494 e BL494) e nenhum igual ou superior a $1 \times 10^{8}$ estruturas infectivas $/ \mathrm{mL}$. O tratamento com maior valor de $\mathrm{CL}_{50}$ foi o BL489, sendo significativamente igual a ele ( $\mathrm{P} \geq$ 0,05) apenas os tratamentos LV457 e CN489.

LV307 foi o tratamento que apresentou o menor valor de CL50. Este foi igual apenas a outros cinco tratamentos, pertencentes a três isolados (494, PL63 e 307), que juntos foram representados por três tratamentos na estrutura de célula de levedura (LV307, LVPL63 e LV494) e três como blastósporo (BL494, BLPL63 e BL307). Embora possuindo os três menores valores de $\mathrm{CL}_{50}$, os resultados da análise conjunta dos cinco isolados em cada estrutura infectiva (Tabela 5) mostraram que não houve diferença significativa $(\mathrm{P} \geq 0,05)$ entre célula de levedura e as demais estruturas infectivas para os dois parâmetros avaliados. Isso sugere que seus níveis de virulência sejam similares entre si a este nível de probabilidade, apesar da CL50 para conídio $\left(2,46 \times 10^{7}\right.$ conídios $\left./ \mathrm{mL}\right)$ ter sido aproximadamente 2,36 vezes maior do que para células de levedura $\left(1,04 \times 10^{7}\right.$ células levedura/mL). 
Tabela 4. Análise de Probit da mortalidade de Tetranychus urticae expostos às três estruturas infectivas (conídio, blastósporo e célula de levedura) produzidas por cinco isolados de Beauveria bassiana (307, 457, 489, 494 e PL63)

\begin{tabular}{|c|c|c|c|c|c|}
\hline Trat. ${ }^{1}$ & $\mathbf{N}^{2}$ & $\begin{array}{c}\mathrm{CL}_{50}(\text { estruturas/mL) } \\
(95 \% \mathrm{IC})^{3}\end{array}$ & $\begin{array}{l}\text { Coef. Angular \# } \\
\text { Desvio Padrão }\end{array}$ & g.l. ${ }^{4}$ & $\chi^{2}$ \\
\hline V 307 & 800 & $4,95 \times 10^{6}\left(2,14 \times 10^{6}-8,83 \times 10^{6}\right) a$ & $1,058 \pm 0,113$ efgh & 5 & 5,3371 \\
\hline LV PL63 & 3200 & $7,44 \times 10^{6}\left(5,01 \times 10^{6}-1,05 \times 10^{7}\right) a b$ & $0,939 \pm 0,077 \mathrm{de}$ & 5 & 1,7743 \\
\hline LV 494 & 800 & $8,28 \times 10^{6}\left(3,49 \times 10^{6}-1,59 \times 10^{7}\right)$ abcd & $0,819 \pm 0,079 \mathrm{abcd}$ & 5 & 6,7098 \\
\hline BL 494 & 1600 & $9,80 \times 10^{6}\left(6,03 \times 10^{6}-1,50 \times 10^{7}\right)$ abcde & $0,786 \pm 0,074 a b c$ & 5 & 1,4856 \\
\hline BL PL63 & 1600 & $1,02 \times 10^{7}\left(7,37 \times 10^{6}-1,38 \times 10^{7}\right) a b c$ & $1,003 \pm 0,077$ efg & 5 & 2,2674 \\
\hline BL 307 & 800 & $1,03 \times 10^{7}\left(7,30 \times 10^{6}-1,40 \times 10^{7}\right) a b c$ & $1,177 \pm 0,099 \mathrm{gh}$ & 5 & 3,8317 \\
\hline $\mathrm{CN} 494$ & 2400 & $1,47 \times 10^{7}\left(9,66 \times 10^{6}-2,10 \times 10^{7}\right)$ bcdef & $1,023 \pm 0,097$ efg & 5 & 1,7825 \\
\hline CN PL63 & 4000 & & $0,955 \pm 0,097 \mathrm{cdef}$ & 5 & 2,6128 \\
\hline $\mathrm{CN} 457$ & 2400 & $2,03 \times 10^{7}\left(1,22 \times 10^{7}-3,11 \times 10^{7}\right) \mathrm{cdef}$ & $0,870 \pm 0,095$ bcde & 5 & 1,2892 \\
\hline BL 457 & 1500 & $2,10 \times 10^{7}\left(9,11 \times 10^{6}-3,51 \times 10^{7}\right)$ bcdef & $1,288 \pm 0,152 \mathrm{~h}$ & 5 & 8,9265 \\
\hline LV 457 & 1800 & $2,62 \times 10^{7}\left(1,45 \times 10^{7}-6,27 \times 10^{7}\right)$ defgh & $0,689 \pm 0,111 \mathrm{ab}$ & 3 & 1,6066 \\
\hline LV 489 & 2400 & $2,85 \times 10^{7}\left(1,75 \times 10^{7}-4,57 \times 10^{7}\right) \mathrm{fg}$ & $0,684 \pm 0,073 \mathrm{a}$ & 5 & 1,5943 \\
\hline CN 307 & 2400 & $3,15 \times 10^{7}\left(1,08 \times 10^{7}-5,46 \times 10^{7}\right)$ cdefg & $1,221 \pm 0,192 \mathrm{fgh}$ & 5 & 6,8123 \\
\hline $\mathrm{CN} 489$ & 1600 & $5,86 \times 10^{7}\left(4,06 \times 10^{7}-8,53 \times 10^{7}\right) \mathrm{gh}$ & $0,884 \pm 0,093$ bcde & 5 & 3,3580 \\
\hline BL 489 & 1600 & $8,21 \times 10^{7}\left(5,48 \times 10^{7}-1,17 \times 10^{8}\right) h$ & $1,091 \pm 0,174$ efgh & 5 & 3,9893 \\
\hline
\end{tabular}

${ }^{1}$ As duas letras iniciais da nomenclatura do tratamento representam a estrutura infectiva avaliada $(\mathrm{CN}-$ conídio; BL - blastósporo; LV - célula de levedura) e as demais letras e/ou números representam a identificação do isolado de Beauveria bassiana

${ }^{2}$ Número de ácaros testados

${ }^{3}$ Valores seguidos pela mesma letra na coluna não diferem significativamente $(\mathrm{P} \geq 0,05)$

${ }^{4}$ Graus de liberdade. 
Tabela 5. Análise de Probit da mortalidade de Tetranychus urticae expostas às estruturas infectivas produzidas por Beauveria bassiana

\begin{tabular}{|c|c|c|c|c|c|}
\hline Estrutura & $\mathbf{n}^{1}$ & $\begin{array}{c}\mathrm{CL}_{50} \text { (estruturas/mL) } \\
(95 \% \mathrm{IC})^{2}\end{array}$ & $\begin{array}{l}\text { Coef. Angular \# } \\
\text { Desvio Padrão }\end{array}$ & g.l. ${ }^{3}$ & $x^{2}$ \\
\hline Levedura & 9000 & $1,04 \times 10^{7}\left(6,46 \times 10^{6}-1,60 \times 10^{7}\right) a$ & $0,846 \pm 0,080 \mathrm{a}$ & 5 & 1,1994 \\
\hline Blastósporo & 7100 & $1,69 \times 10^{7}\left(1,12 \times 10^{7}-2,41 \times 10^{7}\right) \mathrm{a}$ & $0,946 \pm 0,089 \mathrm{a}$ & 5 & 0,6663 \\
\hline Conídio & 12800 & $2,46 \times 10^{7}\left(1,55 \times 10^{7}-3,63 \times 10^{7}\right) \mathrm{a}$ & $0,942 \pm 0,104 \mathrm{a}$ & 5 & 0,5526 \\
\hline
\end{tabular}

${ }^{1}$ Número de ácaros testados

${ }^{2}$ Valores seguidos pela mesma letra na coluna não diferem significativamente $(P \geq 0,05)$

${ }^{3}$ Graus de liberdade.

O valor da $\mathrm{CL}_{50}$ para blastósporo $\left(1,69 \times 10^{7}\right.$ blastósporos $\left./ \mathrm{mL}\right)$ foi intermediário entre célula de levedura e conídio, consequentemente, apresentando grandes áreas de sobreposição em seus intervalos de confiança. Isso sugere uma grande similaridade de resposta desta estrutura com a célula de levedura e o conídio. O mesmo não se emprega para a célula de levedura e o conídio, pois apresentaram pequena área de sobreposição em seus intervalos de confiança. Este comportamento pode também ser observado pela disposição das linhas de tendências traçadas para cada estrutura, a partir dos resultados de sua concentração-mortalidade (Figura 6). Nesta representação, as linhas de tendência de conídio e blastósporo são muito próximas entre si, enquanto que a linha representativa da célula de levedura situa-se mais elevada e distante das demais. Houve aproximação entre as linhas de blastósporo e célula de levedura, principalmente, a partir das concentrações superiores a $1 \times 10^{7}$ estruturas infectivas/mL (Log Concentração $\geq 7,0$ ), enquanto que as linhas para célula de levedura e conídio se mantiveram sempre distantes para todas as concentrações avaliadas. 


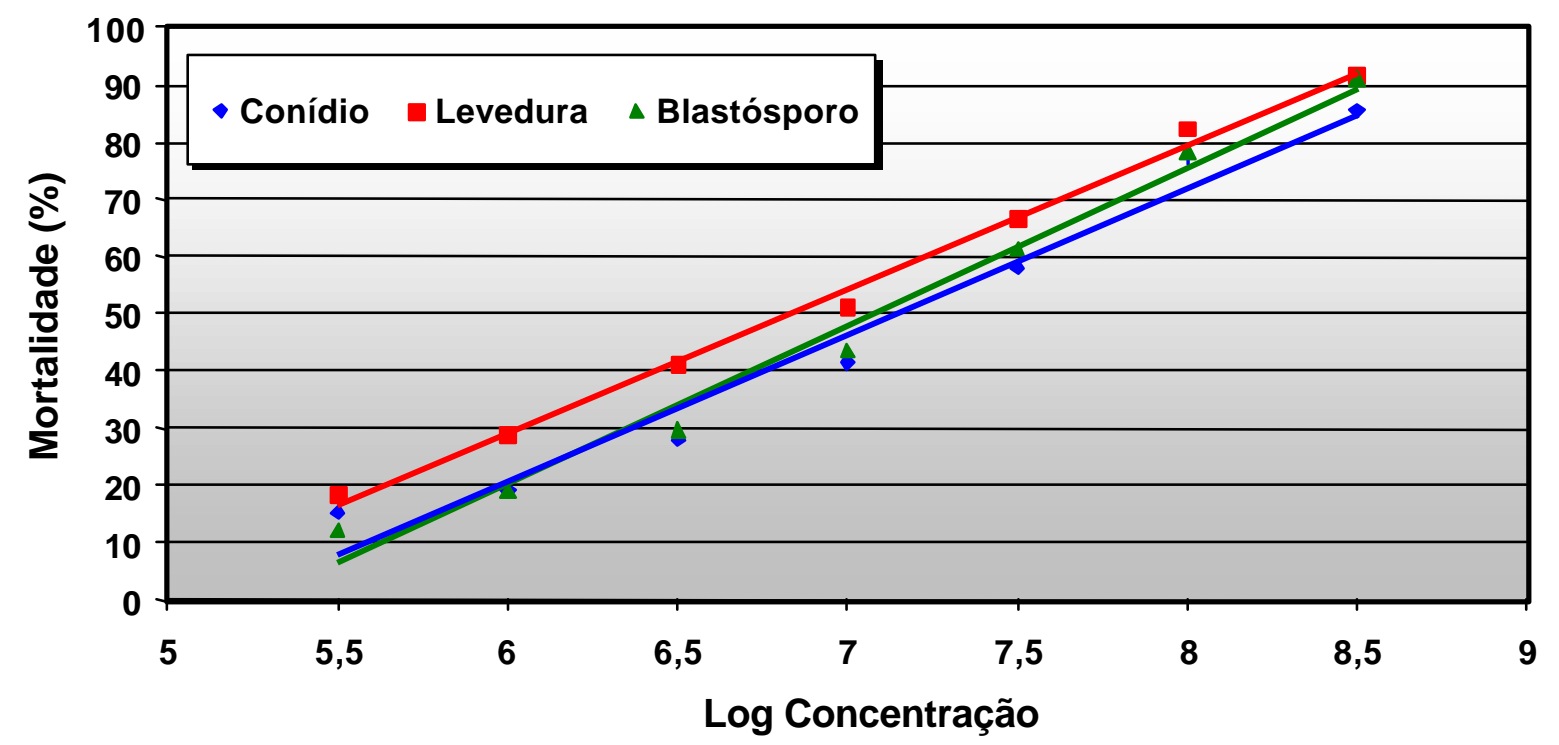

Figura 6 - Curva de concentração-mortalidade de Tetranychus urticae pela inoculação das estruturas infectivas (conídio, blastósporo e células de levedura) produzidas por Beauveria bassiana.

Houve diferenças significativas $(\mathrm{P} \geq 0,05)$ para a $\mathrm{CL}_{50}$ entre as estruturas infectivas em um mesmo isolado de B. bassiana (Tabela 4). Diferenças significativas entre conídio e célula de levedura foram observados apenas para os isolados 307 e PL63, e entre célula de levedura e blastósporo para o isolado 489. Contudo, para todos os isolados não houve diferenças entre conídio e blastósporo, confirmando os resultados observados pela análise conjunta dos isolados (Tabela 5). Em apenas um isolado (457) o valor da $\mathrm{CL}_{50}$ da célula de levedura não foi numericamente o menor entre as três estruturas infectivas estudadas. Estes resultados demonstram que existe apenas um padrão bem definido, o de que conídio e blastósporo apresentam comportamento muito semelhante entre si na capacidade de causar morte em adultos de T. urticae.

Foram também observadas diferenças entre os isolados de B. bassiana. Os isolados 494, PL63 e 307 não apresentaram diferenças entre si para nenhuma das estruturas infectivas quanto a $\mathrm{CL}_{50}$, contudo, o isolado 489 foi em todas as situações inferior e significativamente diferente do PL63 e 494 (Tabela 4). Considerando-se a CL50 como parâmetro para seleção de isolados, o 489 não deve ser considerado para o 
desenvolvimento de formulações microbianas para o controle de T. urticae, pois elevados valores de $\mathrm{CL}_{50}$ implicam na necessidade de concentrações superiores a de outros isolados mais virulentos para se obter uma mesma eficiência de controle, encarecendo deste modo o custo de controle da praga.

São conhecidas muitas diferenças entre as estruturas infectivas produzidas por B. bassiana, sendo os aspectos morfológicos um dos mais facilmente observados. Assim, o conídio aéreo possui o formato esférico com superfície rugosa, o blastósporo é alongado com superfície lisa, enquanto que o conídio submerso é elipsoidal e com superfície intermediária (Hegedus et al., 1990). A superfície destas estruturas também revelam diferenças que têm importantes implicações no controle de pragas, como a hidrofobicidade. Esta propriedade está relacionada à adsorção das estruturas infectivas de diversos fungos entomopatogênicos à cutícula do inseto (Boucias et al., 1988), constituindo-se desse modo na etapa inicial do ciclo de relações entre patógenohospedeiro. A hidrofobicidade se manifesta mais intensamente em conídios aéreos e submersos de B. bassiana do que no blastósporo, além disso, maiores quantidades de lectinas também são encontradas sobre os conídios, conferindo desta maneira uma adesão mais forte ao tegumento do hospedeiro, e consequentemente, favorecendo a germinação dos mesmos. A adesão determina, em parte, sua própria virulência à espécie hospedeira (Hegedus et al., 1992). Os "rodlets", que também são estruturas associadas à adesão dos propágulos ao hospedeiro, são encontrados na superfície dos conídios aéreos e submersos, mas não em blastósporo (Bidochka et al., 1995), comprovando, deste modo, uma menor capacidade natural de adesão do blastósporo ao tegumento de seus hospedeiros. Esta limitação torna-se mais importante em situações em que o hospedeiro esta exposto à condições do ambiente cujos efeitos contribuem para a remoção destas estruturas da superfície do hospedeiro como chuva e vento, e também para insetos sociais como formigas e cupins que possuem capacidade de limpeza do tegumento (grooming) (Alves \& Lecuona, 1998).

Diferenças quanto à virulência das estruturas infectivas de B. bassiana são também bem documentadas, e seus resultados são em alguns casos opostos para os parâmetros $\mathrm{CL}_{50}$ e TL50. Na pesquisa conduzida por Lane et al. (1991b) foi observado 
que a CL50 para blastósporo foi, significativamente, maior do que para conídios aéreos, enquanto que Hegedus et al. (1992) e Miranpuri \& Khachatourians (1994) obtiveram valores de $\mathrm{TL}_{50}$ inferiores para o blastósporo, quando comparado com os de conídios aéreo e submerso. Por sua vez, Vandenberg et al. (1998) não observaram diferenças significativas quanto ao tempo de sobrevivência de pulgões após inoculação com blastósporo fresco, blastósporo desidratado e conídio aéreo produzidos pelo fungo $P$. fumosoroseus.

Embora a $\mathrm{CL}_{50}$ e o $\mathrm{TL}_{50}$ sejam importantes parâmetros, e muitas vezes preconizados, como forma de seleção de isolados ou estruturas infectivas de fungos entomopatogênicos para uso no controle microbiano, outras características devem ser consideradas, como a produção em escala comercial, sobrevivência e estabilidade das estruturas infectivas em condições de armazenamento, entre outras.

$\mathrm{Na}$ América Latina, os fungos $B$. bassiana e $M$. anisopliae são utilizados predominantemente na forma de conídios aéreos, produzidos em meios sólidos sobre grãos de cereais (Alves et al. dados não publicados). No Brasil, esta técnica têm sido empregada com sucesso pelas principais empresas do setor, com objetivo de controle de diversas espécies de cigarrinhas (Hemiptera: Cercopidae), ácaros (Acari: Tetranychidae), cupins (Isoptera: Termitidae), mosca-branca (Hemiptera: Aleyrodidae) e besouros (Coleoptera: Scolytidae) que ocorrem causando danos em culturas como canade-açúcar, pastagens, mamão, café e hortícolas (Alves, 1998a; Faria \& Magalhães, 2001). Neste sistema de produção o entomopatógeno é formulado como pó-molhável (PM) utilizando-se o substrato de crescimento moído como inerte da formulação. Nenhum adjuvante é acrescentado a estes produtos microbianos durante sua formulação, como forma de tornar o produto mais eficiente. Contudo, acredita-se que o próprio grão moído possa conferir características que auxiliam no controle das pragas. Neste caso é interessante avaliar o efeito das exotoxinas e do micélio produzido pelo fungo durante seu crescimento no substrato, bem como do amido e outros elementos nutricionais do próprio grão.

Fungos como $B$. bassiana e $M$. anisopliae são conhecidos por produzirem diversas exotoxinas e enzimas com propriedades tóxicas a insetos pragas, e sua 
utilização têm sido proposta de diferentes maneiras (Roberts \& Krasnoff, 1998). Sua provável presença na formulação de grãos moídos pode supor uma melhora na eficiência dos conídios em causar doença, quer seja por ação tóxica direta ou por simples estresse ao organismo praga. Além destas substâncias, esta formulação contêm fragmentos de micélio do fungo, que sob condições adequadas podem vir a se regenerar e reiniciar o seu desenvolvimento até a formação de conídios infectivos (Batista Filho et al., 1998), aumentando deste modo a quantidade de inóculo no ambiente. Estes autores, também enaltecem a importância de certas formulações ricas em amido e nutrientes. Estes compostos podem ser utilizados pelos fungos para sua germinação, ou para conferir proteção quanto à radiação solar e durante o armazenamento, além de conferir uma melhor adesão do produto sobre a parte vegetativa da planta mesmo sob chuva. Embora este tipo de formulação tenha qualidades importantes, é ainda necessário pesquisas para torna-las mais eficientes.

Embora a produção de grandes quantidades de blastósporos seja possível para B. bassiana, sua baixa sobrevivência após a produção tem limitado consideravelmente seu interesse para uso em formulações comerciais. Sob diferentes condições de armazenamento, esporos aéreos e submersos deste fungo mantém sua viabilidade por um período mais prolongado do que os blastósporos (Lane et al., 1991a; Hegedus et al., 1992). Melhorias nas técnicas de produção dos blastósporos têm avançado no sentido de aumentar a sobrevivência dos blastósporos de fungos com $B$. bassiana e $P$. fumosoroseus durante armazenamento (Lane et al., 1991ab; Jackson et al., 1997).

Tendo em vista a situação atual dos conhecimentos de produção e formulação de fungos entomopatogênicos no país, o uso do conídio aéreo têm sido preferido. Para esta estrutura infectiva o isolado 489 foi, significativamente, inferior aos demais isolados (307, 457, 494 e PL63) quanto a $\mathrm{CL}_{50}$ (Tabela 4), não sendo deste modo recomendado para uso no controle de T. urticae. Dos quatro isolados restantes, o PL63, 494 e 307 foram os mais produtivos em conídios aéreos pelo sistema de produção mais utilizado no Brasil, e significativamente superiores ao 457 (Tamai, 1998). Deste modo, com base em sua produção de conídios e patogenicidade a T. urticae, os isolados PL63, 494 e 307 são 
os mais apropriados para serem desenvolvidos para o controle desta praga com a utilização de conídios aéreos.

A "fase de levedura" de fungos entomopatogênicos é pouco conhecida e pode ser considerada como umas das etapas do ciclo destes agentes em um artrópodo. É frequentemente observada dentro do corpo do hospedeiro, desenvolvendo ação colonizadora. Alguns autores já relataram a presença de estruturas leveduriformes de $B$. bassiana, variáveis na forma, tamanho e características nucleares, em meios líquidos e na hemolinfa de insetos (Lima \& Tigano, 1989), no entanto, para o gênero Beauveria a fase de levedura só foi obtida recentemente em meio de cultura sólido MacConkey (Alves et al., 2002. Comunicação pessoal). Pouco se conhece sobre a morfologia e fatores que regulam o desenvolvimento dos fungos entomopatogênicos (Pendland \& Boucias, 1997), principalmente com relação às possíveis fases leveduriformes dos

principais fungos hifomicetos como V. lecanii, M. anisopliae e B. bassiana. Para Nomuraea. rileyi essa fase é comum em meios sólidos, onde os corpos hifais transformam-se em colônias mucóides (fase leveduriforme) que podem durar de 1 a 7 dias, dependendo da linhagem, para depois formar micélio e completar a esporulação (Pendland \& Boucias, 1997).

A obtenção do estágio leveduriforme bem definido de hifomicetos pode ser importante para os pesquisadores que atuam nas áreas de biologia e nutrição, patologia de insetos (patogênese), controle microbiano (virulência e produção) e engenharia genética (melhoramento).

\subsection{Conclusões}

- conídio aéreo, célula de levedura e blastósporo dos cinco isolados de B. bassiana são patogênicos ao ácaro T. urticae

- diferenças significativas $(\mathrm{P} \geq 0,05)$ para $\mathrm{CL}_{50}$ e coeficiente angular ocorrem entre os isolados e entre as estruturas infectivas de B. bassiana 
- a constatação da patogenicidade da célula de levedura e do blastósporo de B. bassiana a T. urticae traz novas perspectivas para o desenvolvimento de formulações micoacaricidas mais eficientes

- os isolados PL63, 494 e 307 são os mais apropriados para serem desenvolvidos para o controle de $T$. urticae com a utilização de conídios aéreos de B. bassiana. 


\section{TOXICIDADE DE PRODUTOS FITOSSANITÁRIOS PARA Beauveria bassiana}

Resumo

Foram avaliados, quanto a toxicidade para Beauveria bassiana, noventa e três produtos fitossanitários recomendados para o controle de pragas e doenças de culturas olerícolas e ornamentais no Brasil. Os parâmetros considerados foram crescimento vegetativo e reprodução do patógeno em meio de cultura BDA, inoculado com concentrações comerciais dos produtos. Houve grande variação na toxicidade entre as classes de produtos fitossanitários. Os 3 espalhantes adesivos avaliados foram muito tóxicos ao patógeno. Entre os 36 produtos fungicidas, apenas três foram compatíveis, tendo como ingredientes ativos: propamocarb hidrocloreto, enxofre e kasugamycin. Um número maior de produtos acaricida e/ou inseticida foram compatíveis. Assim, dos 54 produtos testados, 24 foram compatíveis e estão distribuídos entre os seguintes ingredientes ativos: abamectin, acefato, acetamiprid, betacyflutrin, bifentrina, ciromazina, deltametrina, diafentiuron, diflubenzuron, dimetoato, fenpropatrina, fenpyroximate, fenvalerate, imidacloprid, metamidofós, propargite, tebufenozide e triclorfon. Houve grande variação na toxicidade dos produtos dentro de cada grupo químico e produtos formulados com a mesma molécula química. Não houve correlação entre tamanho das colônias e produção de conídios de B. bassiana, com alguns produtos estimulando o crescimento da colônia e outros a produção de conídios. Estudos de toxicidade de produtos fitossanitários a inimigos naturais permitem a utilização prática e imediata dos resultados, e também, criam-se novas 
linhas de trabalho que virão complementar e viabilizar a utilização destas duas estratégias de controle em um programa de Manejo Integrado de Pragas.

Palavras-chave: Beauveria bassiana, produto fitossanitário, compatibilidade, manejo integrado.

\section{TOXICITY OF PESTICIDES AGAINST Beauveria bassiana}

\section{Summary}

Ninety-three products used for control of insects and diseases in vegetable and ornamental crops in Brazil were evaluated for their toxic effect against the fungus Beauveria bassiana. Vegetative growth and spore yields were measured on PDA medium mixed with commercial concentrations of the products. There was large variability in the toxicity of different classes of the products. Three spreader/stickers were very toxic to the entomopathogen. Among the thirty-six fungicides tested, only three were compatible with B. bassiana: propamocarb hydrochloride, sulfur and kasugamycin. Greater proportion of insecticides and mitecides were compatible with the fungus. Among fifty-four insecticides or mitecides, twenty-four were compatible with $B$. bassiana including those with the following active ingredients: abamectin, acephate, acetamiprid, betacyfluthrin, bifenthrin, cyromazine, deltamethrin, diafentiuron, diflubenzuron, dimethoate, fenpropathrin, fenpyroximate, fenvalerate, imidacloprid, methamidophos, propargite, tebufenozide and trichlorfon. There was large variability in the toxicity of products within a chemical group and products containing the same active ingredient. There was no correlation between the colony diameter and conidial yield, because some products affected vegetative growth while others affected conidial production. Studies on the toxicity of pest control products against natural enemies provide practical results that can be used immediately. Also, these studies open new 
research possibilities that could complement or allow the use of these two control strategies in a program of integrated pest management.

Keywords: Beauveria bassiana, pesticides, compatibility, integrated pest management.

\subsection{Introdução}

No Brasil, o controle de pragas e doenças em culturas hortícolas (ornamentais e olerícolas) cultivadas em campo aberto ou ambiente protegido (estufa) é feito quase exclusivamente com produtos químicos (Villas Bôas, 1989; Oliveira, 1995). Este fato ocorre devido a tradição do uso desses produtos junto aos produtores, facilidade de aplicação e disponibilidade de equipamentos e serviços no mercado (Tamai et al., 2000). Contudo, sua integração com outros métodos de controle como a manipulação do ambiente de cultivo, utilização de plantas resistentes, cultural, físico e biológico, representa um progresso desejável ao sistema atual de controle fitossanitário. Isso deve permitir a redução dos custo de produção, menor probabilidade de seleção de pragas e doenças resistentes a produtos químicos, menor intoxicação de trabalhadores e redução dos resíduos nos produtos. Esta integração faz parte do manejo integrado, sendo amplamente utilizado em culturas hortícolas produzidas em estufa na América do Norte e Europa. Um bom exemplo é a Holanda que produz mais de $90 \%$ de todo tomate, pimenta doce e pepino neste sistema de manejo em que se utilizam intensamente insetos polinizadores e inimigos naturais de doenças e pragas (Van Lenteren, 2000).

Na Europa, cerca de 100 agentes de controle biológico são produzidos e comercializados para o controle de pragas em diversas culturas, e juntamente com insetos polinizadores movimentaram cerca de US\$ 70 milhões em 1991. A área de estufa beneficiada com inimigos naturais em sistema de manejo integrado passou de 200 hectares em 1970 para 1400 hectares no final da década de 90 (Van Lenteren et al., 1997). Esta expansão tem sido constantemente incentivada pelos problemas de resistência em populações de pragas e doenças, e recentemente, por políticas governamentais e exigências 
do mercado consumidor (Van Lenteren, 2000). No Brasil, estudo de mercado para a cultura do tomate de mesa revelaram uma demanda crescente por produtos de qualidade superior, em cujos esforços de produção se encontra o menor uso de produtos químicos. Além disso, tem ocorrido uma crescente pressão sobre as grandes redes de varejo, para a oferta de produtos que sejam mais seguros aos consumidores (FNP, 2001). Esta nova situação representa uma grande oportunidade para o desenvolvimento de um sistema de manejo integrado de pragas e doenças para culturas hortícolas no país.

Atualmente, o fungo Beauveria bassiana (Bals.) Vuill. está entre os inimigos naturais com maior potencial de uso em culturas hortícolas no Brasil. Além de possuir ação sobre as principais pragas destas culturas como Bemisia tabaci (Sternorrhyncha: Aleyrodidae), Frankliniella occidentalis (Thysanoptera: Thripidae) e Tetranychus urticae (Acari: Tetranychidae) (Tamai, 1998; Lopes, 1999; Alves et al., 2001b), seus sistemas de aplicação e produção em escala industrial são bastante simples (Alves \& Pereira, 1989). No entanto, a eficiência desse patógeno pode ser muito influenciada pelos inseticidas, acaricidas e fungicidas químicos, adubos foliares e hormônios vegetais utilizados nas culturas (Alves et al., 1998b). O conhecimento prévio do efeito tóxico destes produtos é imprescindível para a determinação de estratégias adequadas de utilização dos entomopatógenos em um sistema de manejo integrado. Produtos compatíveis podem ser utilizados de forma a preservá-los no agroecossistema. Também podem ser empregados em subdosagens associados com patógenos visando aumentar a eficiência do inimigo natural e/ou reduzir a quantidade de resíduos químico nos produtos. A pulverização com produtos incompatíveis deve ser realizada após alguns dias (variável para cada produto) da utilização dos entomopatógenos (Alves \& Lecuona, 1998; Pereira et al., 1998).

Essa pesquisa teve como objetivo avaliar a toxicidade de diversas formulações de produtos fitossanitários ao fungo B. bassiana, visando sua utilização em programas de Manejo Integrado de Pragas (MIP) em culturas ornamentais e olerícolas. 


\subsection{Material e Métodos}

Os testes foram conduzidos in vitro, em meio de cultura BDA (batatadextrose-ágar), adicionando-se os produtos fitossanitários em concentrações preestabelecidas ao meio de cultura fundido, ainda não solidificado. Foram avaliados 93 produtos incluindo espalhantes adesivos, acaricidas, inseticidas, inseticidas/acaricidas, inseticidas/fungicidas, fungicidas, fungicidas/bactericidas e fungicidas/acaricidas recomendados no Brasil, pelo menos para uma das seguintes culturas: ornamentais, morango, tomate, jiló, pimentão, berinjela, abóbora, melão, melancia e pepino. As concentrações utilizadas foram aquelas estabelecidas nos rótulos dos produtos. Após a solidificação do meio de cultura efetuou-se a inoculação do microrganismo, utilizandose uma alça de platina contendo em sua extremidade conídios do fungo B. bassiana, isolado PL63. O inóculo consistiu de placas com culturas puras do fungo, incubadas por 7 a 10 dias em meio de cultura MC (meio para produção de esporos) (Alves et al., 1998c), a $26 \pm 1{ }^{\circ} \mathrm{C}$ e fotofase de 12 horas. A inoculação foi feita em três pontos por placa de Petri acrílica $(8,5 \mathrm{~cm}$ de diâmetro x $1,5 \mathrm{~cm}$ de altura), eqüidistantes entre si, visando-se evitar o contato entre as colônias após o crescimento. Foram preparadas três placas por tratamento, totalizando nove colônias, contudo, na avaliação foram consideradas as 6 colônias (repetições) mais uniformes. As placas foram mantidas em câmara climatizada $\left(26 \pm 1^{\circ} \mathrm{C}\right.$ e fotofase de 12 horas $)$ por 7 dias.

A determinação do efeito tóxico foi realizada avaliando-se os parâmetros crescimento vegetativo e reprodução do patógeno, utilizando-se o modelo de classificação de produtos fitossanitários quanto à toxicidade sobre fungos entomopatogênicos proposto por Alves et al. (1998b). O crescimento vegetativo foi determinado medindo-se os diâmetros das colônias em dois sentidos ortogonais na superfície do meio de cultura, considerando-se o diâmetro médio das mesmas. Para a avaliação da reprodução do patógeno (conidiogênese), essas colônias foram recortadas, juntamente com o meio de cultura, e transferidas individualmente para tubos de vidro contendo $10 \mathrm{~mL}$ de água destilada estéril mais espalhante adesivo (Tween $40^{\circledR}$ ) a $0,1 \%$. Em seguida, os conídios foram removidos da superfície do meio com o auxílio de um 
pincel, e posteriormente homogeneizados em agitador de tubos (2 minutos) e ultrasom (2 minutos), para sua quantificação. Para isso, foram preparadas diluições sucessivas das suspensões de conídios, até que se permitisse a contagem em câmara de Neubauer, ajustando-se os valores entre 30 e 200 conídios por campo de contagem $\left(1,0 \mathrm{~mm}^{2}\right)$.

O sistema de avaliação baseou-se no cálculo das porcentagens médias de esporulação (conidiogênese) e crescimento micelial (vegetativo) das colônias dos fungos, em relação à testemunha (100\%), aplicando-se para classificação o seguinte modelo matemático:

$$
T=\frac{20[C V]+80[E S P]}{100}
$$

onde:

T : valor corrigido do crescimento vegetativo e esporulação para classificação do produto;

$\mathrm{CV}$ : porcentagem de crescimento vegetativo com relação à testemunha;

ESP : porcentagem de esporulação com relação à testemunha.

Com os valores calculados de "T", procedeu-se a comparação com os limites estabelecidos na Tabela 6.

Tabela 6. Valores de "T" para classificação do efeito de produtos químicos sobre fungos entomopatogênicos (Alves et al., 1998b)

\begin{tabular}{cc}
\hline Valor de $\mathbf{T}$ & Classificação do produto \\
\hline 0 a 30 & Muito tóxico \\
31 a 45 & Tóxico \\
46 a 60 & Moderadamente tóxico \\
$>60$ & Compatível \\
\hline
\end{tabular}


Dessa forma, de acordo com as faixas determinadas pelo modelo todos os produtos fitossanitários estudados foram classificados com relação à sua toxicidade para o fungo B. bassiana.

\subsection{Resultados e Discussão}

A classificação dos 93 produtos fitossanitários quanto a toxicidade ao fungo B. bassiana, isolado PL63, encontra-se na Tabela 7 e, estão assim distribuídos nos 4 níveis de classificação: a) 22 (23,6\%) compatíveis; b) 5 (5,4\%) moderadamente tóxicos; c) $6(6,5 \%)$ tóxicos; d) $60(64,5 \%)$ muito tóxicos. A distribuição dos produtos nos níveis de classificação foram bastante diferentes entre as classes de produtos fitossanitários. Os 3 espalhantes adesivos foram muito tóxicos ao fungo, enquanto que entre os 36 produtos com ação predominantemente fungicida (fungicida, fungicida/acaricida ou fungicida/bactericida), 3 (8,3\%) foram compatíveis, 1 (2,8\%) tóxico e 32 (88,9\%) muito tóxicos. Já os de ação acaricida e/ou inseticida (inseticida, inseticida/acaricida ou inseticida/fungicida) reunidos representaram 54 produtos, assim distribuídos: 19 (35,1\%) compatíveis; 5 (9,3\%) moderadamente tóxicos; 5 (9,3\%) tóxicos e 25 (46,3\%) muito tóxicos. Com isso, aproximadamente $92 \%$ dos produtos com ação fungicida foram classificados como tóxicos ou muito tóxicos, contra 56\% dos inseticidas e/ou acaricidas.

A maior toxicidade dos fungicidas a B. bassiana e outras importantes espécies de fungos entomopatogênicos, quando comparados aos inseticidas e/ou acaricidas é também relatada em trabalhos da International Organization for Biological Control (IOBC) (Hassan et al., 1987; 1988; 1991; 1994; Sterk et al., 1999), entidade européia com diversos colaboradores em órgãos de pesquisa, empresas do setor agrícola, extensionistas e produtores, com o propósito de gerar conhecimentos para difusão do controle biológico na agricultura. Nestes trabalhos, 35 (92\%) produtos inseticidas e/ou acaricidas testados são inofensivos ou levemente prejudiciais ao fungo entomopatogênico Verticillium lecanii (Zimm.) Viègas, contra 10 (33\%) dos fungicidas. Para B. bassiana, 18 (95\%) produtos inseticidas e/ou acaricidas testados foram 
inofensivos ou levemente prejudiciais, mas apenas $11(52 \%)$ para os fungicidas. A mesma tendência também foi observada para as espécies Beauveria brongniartii e Metarhizium anisopliae porém, para um número restrito de produtos testados. Estes entomopatógenos são comercializados na Europa e América do Norte como componentes de produtos como o $\operatorname{Vertalec}^{\circledR}, \operatorname{Mycotal}^{\circledR}$ (V. lecanii), Botanigard ${ }^{\circledR} \mathrm{e}$ Naturalis $^{\circledR}$ (B. bassiana) para o manejo de pulgões, tripes e moscas brancas em estufa. Quando se considera o efeito tóxico sobre o parasitóide Encarsia formosa (Hymenoptera: Aphelinidae) e também a uma linhagem resistente a produtos químicos do ácaro predador Phytoseiulus persimilis (Acari: Phytoseiidae), o resultado é o oposto aos entomopatógenos, como esperado, os inseticidas e/ou acaricidas são normalmente os mais tóxicos. Estes dois organismos estão entre os inimigos naturais mais comercializados para o controle de moscas brancas e ácaros tetraniquídeos em estufas na Europa (Van Lenteren et al., 1997). Nestes trabalhos da IOBC, os herbicidas se mostraram muito seletivos a todos estes inimigos naturais, onde 15 (93\%) produtos testados foram inofensivos ou levemente prejudiciais a E. formosa, 19 (79\%) para $P$. persimilis, 16 (75\%) para V. lecanii, $14(74 \%)$ para B. bassiana e $9(89 \%)$ para $B$. brongniartii.

O nível de toxicidade dos produtos fitossanitários aos fungos entomopatogênicos é determinado pela sua natureza química (ingrediente ativo e inertes) e concentração, da interação destes dois fatores, além da espécie e linhagem do entomopatógeno (Alves et al., 1998b). O modo de ação do ingrediente ativo é possivelmente um dos principais fatores envolvidos. A grande toxicidade de moléculas como mancozeb, maneb, captan, folpet, clorotalonil e oxicloreto de cobre já era esperada, pois, pertencem ao grupo dos fungicidas protetores, que se caracterizam por apresentarem atividades em múltiplos sítios de ação, afetando um grande número de processos vitais de fungos fitopatogênicos (Guini \& Kimati, 2000). Uma exceção neste grupo de fungicidas foi o enxofre (Kumulus ${ }^{\circledR} \mathrm{DF}$ ), que se mostrou compatível a $B$. bassiana. A seletividade do enxofre é também conhecida para outras espécies de fungos entomopatogênicos como M. anisopliae e V. lecanii (Alves et al., 2000), constituindo-se em um importante produto a ser utilizado em programas de manejo integrado de pragas 
e doenças em culturas como citros, pêssego e café, que apresentam algumas de suas importantes pragas controladas naturalmente por estes entomopatógenos (Alves, 1998a).

Moléculas compatíveis como propamocarb hidrocloreto e kasugamycin pertencem ao grupo dos fungicidas sistêmicos que agem de forma específica, inibindo preferencialmente um ou poucos processos vitais, sendo mais seletivos a um número limitado de grupos taxonômicos de fungos. No caso do propamocarb hidrocloreto, seu mecanismo de ação é seletivo para fungos oomicetos (Guini \& Kimati, 2000), cujo sítio de ação talvez não seja compartilhado por este isolado de B. bassiana. Porém, outros estudos são necessários para comprovar esta hipótese. O produto comercial Tattoo ${ }^{\circledR} \mathrm{C}$ (propamocarb hidrocloreto + clorotalonil) é classificado como tóxico ao fungo. Possivelmente sua toxicidade esta relacionada ao efeito prejudicial do clorotalonil (fungicida protetor) na formulação, pelo fato deste composto ter se mostrado muito toxico nos produtos Daconil 500 e Dacostar 750. Os demais fungicidas sistêmicos testados foram muito tóxicos para $B$. bassiana, como benomyl, tiofanato metílico, tebuconazole e iprodione.

Apesar dos inseticidas e/ou acaricidas agirem, de forma geral, em pontos específicos da fisiologia de insetos e ácaros, como os neurotóxicos (com ação sobre a transmissão axônica e sináptica) e os reguladores de crescimento (inibidores da síntese de quitina e os agonistas e/ou antagonista do hormônio juvenil) (Omoto, 2000), o modo de ação não determina que produtos pertencentes a estes grupos sejam seletivos a $B$. bassiana. Outros fatores podem estar envolvidos, como os sítios secundários de ação, quantidade e componentes da formulação e sua capacidade de alterar o $\mathrm{pH}$ (potencial hidrogeniônico) do meio de cultura. Um exemplo que ilustra estas possibilidades foi a grande variação observada na toxicidade entre os reguladores de crescimento de insetos. Neste grupo, os produtos Dimilin (diflubenzuron) e Mimic 240 SC (tebufenozide) foram compatíveis, Trigard (ciromazina) foi moderadamente tóxico e os produtos Applaud 250 (buprofezin) e Match CE (lufenuron), além de dois produtos a base do piriproxifen (Cordial 100 e Tiger $100 \mathrm{CE}$ ) foram muito tóxicos ao patógeno. Nesta relação, as moléculas diflubenzuron e lufenuron foram compatível e muito tóxico para B. bassiana, respectivamente, apesar de pertencerem ao mesmo grupo químico, as benzoilfeniluréias 
(derivado da uréia), que agem inibindo a síntese da quitina dos insetos (Retnakaran et al., 1985). Nos grupos químicos dos piretróides e organofosforados (neurotóxicos) que tiveram muitos produtos avaliados, também houve grande variação na toxicidade a este isolado de $B$. bassiana. Esses resultados podem estar relacionados com a ação dos ingredientes da formulação desses produtos.

Uma discussão sobre o efeito do tipo de formulação dos produtos fitossanitários sobre B. bassiana foi feito por Anderson \& Roberts (1983). Os autores observaram que formulações de inseticidas do tipo concentrado emulsionável (CE) estão, freqüentemente, associadas com a inibição da germinação dos conídios deste fungo, ao contrário das formulações como pós molháveis (PM) e "flowables" que geralmente não causam inibição e, muitas vezes, favorecem o crescimento deste patógeno. Porém, estas informações não permitem generalizações. Nesta pesquisa com o isolado PL63, houve casos em que o tipo de formulação interferiu na toxicidade a $B$. bassiana, como por exemplo, os produtos comerciais Bulldock 125 SC (suspensão concentrada) e Turbo (concentrado emulsionável), que apesar de possuírem a mesma molécula inseticida o betacyflutrin, foram classificados como compatível e tóxico, respectivamente. A única diferença entre estes produtos foi o tipo da formulação apesar de serem produzidos pelo mesmo fabricante (Bayer) e apresentarem a mesma recomendação (1,25 g ingrediente ativo por 100 litros de água).

No mercado de produtos fitossanitários é possível encontrar diversos produtos comerciais formulados com a mesma molécula química, mas pertencentes a fabricantes diferentes, como é o caso do metamidofós produzido pela Hokko (Hamidop 600), Agripec (Stron) e Bayer (Tamaron BR) avaliados neste trabalho. Neste caso, todos os produtos foram compatíveis com B. bassiana. Porém, a toxicidade pode ser diferente, como foi o caso do dimetoato produzido pela Milenia (Dimetoato CE Milenia), AgrEvo (Dimexion) e Sipcam (Tiomet $400 \mathrm{CE}$ ) onde o primeiro foi muito tóxico e os demais compatíveis. Apesar de serem formulados como concentrado emulsionável (CE), a causa da toxicidade pode estar relacionada com os constituintes de cada formulação que não o ingrediente ativo. Neste caso, não há evidências de que a quantidade de ingrediente ativo (dimetoato) no meio de cultura tenha interferido na toxicidade ao entomopatógeno, já 
que o produto Tiomet $400 \mathrm{CE}$, que foi compatível, foi avaliado na concentração de $80 \mathrm{~g}$ de ingrediente ativo por 100 litros de água, valor 60\% maior do que o utilizado no teste com o produto Dimetoato CE Milenia, que foi incompatível.

Tabelas de compatibilidade de produtos químicos a entomopatógenos publicadas por Alves et al. (1998b), usando informações próprias e disponíveis na literatura, demonstram que o nível de toxicidade de um produto pode estar diretamente relacionado com sua concentração no meio de cultura e, também à espécie do entomopatógeno alvo. De forma geral, a toxicidade para fungos como B. bassiana, $M$. anisopliae, $V$. lecanii, Hirsutella thompsonii e Nomuraea rileyi aumenta a medida que o produto químico se torna mais concentrado no meio de cultura. Porém, existem produtos que são muito tóxicos mesmo em concentrações muito reduzidas. No trabalho de Todorova et al. (1998), produtos comerciais contendo as moléculas fungicidas clorotalonil ou maneb, em concentrações até 10 vezes menor do que o recomendado pelo fabricante, inibiram completamente o crescimento micelial de $B$. bassiana em meio de cultura líquido, além do crescimento da colônia e esporulação em meio de cultura sólido.

A variabilidade genética natural entre isolados de uma mesma espécie de fungo entomopatogênico é bastante conhecida e amplamente relatada na literatura para diversos parâmetros biológicos, como a patogenicidade a um organismo alvo. Esta variabilidade ocorre também para a sensibilidade a produtos químicos sintéticos (Olmert \& Kenneth, 1974; Paccola-Meirelles \& Azevedo, 1990; Liu et al., 1993), e tem sido utilizada por Todorova et al. (1998) para explicar, em parte, as diferentes respostas de $B$. bassiana na presença de um mesmo produto químico, que se encontram publicados. Por essa razão, estes mesmos autores utilizaram em seu trabalho de seletividade um isolado de B. bassiana previamente selecionado quanto a alta patogenicidade para o inseto alvo (Leptinotarsa decemlineata) e compatível com o predador da praga Coleomegilla maculata lengi (Coleoptera: Chrysomelidae, Coccinellidae).

No que se refere ao efeito do $\mathrm{pH}$, é pouco provável que as reduzidas quantidades dos produtos químicos adicionados ao meio de cultura possam ter modificado substancialmente seu valor ao ponto de prejudicar o crescimento e produção 
de conídios do isolado PL63. As recomendações da maioria dos produtos testados compreende valores quase sempre inferiores a $200 \mathrm{~mL} / \mathrm{g}$ por 100 litros de água, fazendo com que sua participação na calda resultante seja inferior a 0,2\%. Entretanto, é uma questão que merece ser melhor investigada.

Pela análise dos valores de "T", observa-se que alguns produtos tiveram valores muito superiores a 100, como é o caso do Kumulus DF $(149,51)$, Cefanol $(198,48)$, Dipterex $500(261,95)$ e Confidor $(288,24)$. Pela fórmula, produtos com valores próximos a 100 apresentaram comportamento muito semelhante à testemunha para os parâmetros avaliados. No caso destes quatro produtos, sua presença no meio de cultura representou um estímulo a produção de conídios, mas nem sempre ao crescimento da colônia do entomopatógeno. Para os produtos Kumulus DF, Cefanol, Dipterex 500 e Confidor o acréscimo na produção de conídios, quando comparados com a testemunha, foram de aproximadamente 72, 127, 210 e 221\%, respectivamente. Quanto ao diâmetro de colônia, não houve diferença entre Confidor e testemunha, contudo, para o Kumulus DF, Cefanol e Dipterex 500 o diâmetro médio de suas colônias foram 47, 15 e 40\% menor do que a testemunha, respectivamente. Neste caso, os valores elevados de "T" foram determinados pelo bom desempenho na produção de conídios, isto porque, sua fórmula atribuiu $80 \%$ de participação deste parâmetro na composição final do valor. A maior produção de conídios de B. bassiana na presença destes produtos no meio de cultura, pode ter ocorrido pela utilização como nutriente de algum (s) componente (s) mineral (ais) solúvel (eis) presente (s) nas formulações químicas, e/ou provenientes da degradação de moléculas complexas, como o ingrediente ativo, promovidas pelo entomopatógeno.

A capacidade de degradação de produtos fitossanitários por diferentes gêneros de fungos é conhecida, e amplamente relatada na literatura. No trabalho conduzido por Tixier et al. (2000), o fungo B. bassiana foi capaz de degradar quantidades consideráveis do herbicida diuron (derivado da uréia) em aproximadamente 24 horas. Neste caso, o nível de toxicidade dos produtos resultantes foi maior do que o próprio diuron quando avaliado para a bactéria Vibrio fischeri, utilizada como indicador biológico. É possível que este fenômeno possa ter ocorrido para alguns produtos testados com o isolado PL63. 
Fungos deuteromicetos como B. bassiana e $M$. anisopliae, de modo geral, são fáceis de serem cultivados em meio de cultura sólido ou líquido, contudo, podem ser afetados, em níveis variados, pela composição nutricional do meio. Li \& Holdom (1995) demonstraram que a germinação, tamanho de colônia e produção de conídios de dois isolados de M. anisopliae são estimulados e/ou inibidos de acordo com a fonte de carbono e nitrogênio presentes no meio de cultura, e também, que nem sempre existe correlação direta entre tamanho de colônia e produção de conídios. Deste modo, alguns compostos nitrogenados favoreceram o crescimento da colônia e não beneficiaram a produção de conídios. Observou-se também que onde a produção de conídios foi intensa, o diâmetro da colônia foi similar ou menor do que a testemunha. Estes pesquisadores observaram que a densidade das colônias (relação entre seu tamanho e altura), pode explicar o fenômeno de culturas menores, embora mais altas (mais densas), produzirem mais conídios do que outras maiores, porém mais baixas (menos densas).

A partir dos resultados obtidos com o isolado PL63, é possível fazer algumas considerações quanto as possibilidades de utilização do fungo B. bassiana em programas de MIP em culturas ornamentais e olerícolas no Brasil. Dentro de certos limites, estas considerações podem ser estendidas para outras espécies de fungos entomopatogênicos com potencial de uso neste seguimento da agricultura como $M$. anisopliae, V. lecanii e Paecilomyces fumosoroseus (Lopes et al., 2000; Ramos \& Alves, 2001).

A expressiva toxicidade dos fungicidas é um dos fatores que mais limitam a utilização deste grupo de agente de controle biológico. Assim, é importante a utilização dos fungicidas compatíveis selecionados: Previcur N (propamocarb hidrocloreto), Kumulus DF (enxofre) e Hokko Kasumin (kasugamycin). Porém, sua utilização precisa ser considerada sobre dois aspectos: a eficiência de controle das doenças e a possibilidade do desenvolvimento de resistência pelos fitopatógenos. A eficiência de controle é dependente da espécie e linhagem do fitopatógeno a ser controlada, tendo em vista que estes produtos podem não ser eficientes para impedir a disseminação da doença na cultura. Quanto a resistência, a reduzida disponibilidade de produtos para rotação dificulta sua prevenção, especialmente para culturas produzidas intensivamente durante todo o ano e na mesma área, como é o caso de muitas ornamentais. Existe também o caso em que o problema da 
resistência é agravado quando o produtor faz, sem intenção, a rotação de culturas com espécies de plantas da mesma família, que compartilham geralmente as mesmas doenças e pragas.

Outros fatores importantes para a utilização dos fungicidas compatíveis envolvem a necessidade de registro para as culturas, o custo/hectare, a disponibilidade do produto compatível no mercado, e a hipótese de vir a ser retirado do mercado pela empresa produtora.

Algumas formas de reduzir o efeito restritivo dos fungicidas à utilização de fungos entomopatogênicos é a adoção conjunta de diversas medidas de controle que minimizem a presença de fitopatógenos na cultura e, consequentemente, a necessidade de aplicações de fungicidas para seu controle, como por exemplo: utilização de mudas sadias; uso de variedades resistentes; manejo da irrigação; remoção de mudas e plantas doentes (Zambolim et al., 1999). Outra possibilidade, é a aplicação do fungicida apenas onde a doença se encontra, ou seja, nos focos, e também pulverizando-se o fungicida com intervalo de tempo suficiente para não coincidir com as fases mais suscetíveis da interação entomopatógeno-hospedeiro. Para o controle de T. urticae com B. bassiana este período compreende as primeiras 48 horas após a pulverização do fungo, tempo necessário para a germinação dos conídios e invasão do hospedeiro pelo entomopatógeno (Neves et al., 1997). Estes procedimentos são conhecidos por seletividade ecológica do produto químico através do espaço e tempo, respectivamente (Yamamoto et al., 1992). A empresa Mycotech-USA, que comercializa o produto Botanigard ${ }^{\circledR}$ contendo B. bassiana, fornece aos seus clientes informações por via impressa ou eletrônica (www.mycotech.com), sobre a possibilidade de mistura deste entomopatógeno e produtos químicos (inseticidas, acaricidas, fungicidas, herbicidas, espalhantes, etc.) no tanque pulverizador, e o tempo entre as aplicações destes agentes de controle quando forem incompatíveis entre si.

Para os produtos acaricida e/ou inseticida as possibilidades para sua utilização com B. bassiana são melhores. Com 24 (44\%) produtos compatíveis ou moderadamente tóxicos, pertencentes a diferentes grupos químicos (derivado do pyrazol, derivado do fenoxi ciclohexil, piretróide, nitroguanidina, derivado da uréia, diacylhydrazina, cloronicotinil, triazina, tiouréia, organofosforado) permite-se manejar a resistência a 
produtos químicos das principais pragas das culturas hortícolas, usando-se a rotação de produtos com diferentes modos de ação. Estes produtos podem ser aplicados conjuntamente com o isolado PL63, na mesma calda inseticida, para o controle da mesma praga ou pragas diferentes. Em se tratando da mesma praga, pode-se utilizá-los em concentração máxima recomendada, na estratégia conhecida como manejo por ataque múltiplo, ou em subconcentrações. Neste último caso, o produto químico poderia atuar como um sinergista do entomopatógeno, auxiliando a infecção fúngica. Nessa estratégia, o controle proporcionado pelo produto químico e entomopatógeno em mistura deve ser superior a soma dos resultados de controle observados para cada uma destas táticas separadamente.

Com base em algumas informações disponíveis na literatura, as razões que levam ao efeito sinérgico podem ser consideradas sobre o ponto de vista da praga e do entomopatógeno, ou ambos simultaneamente. No que se refere a praga, o produto químico pode atuar interferindo em seu comportamento, por exemplo: na capacidade de limpeza e trofolaxia de cupins (Neves \& Alves, 2000a) ou afetando o comportamento de larvas de coleópteros, fazendo com que as mesmas permaneçam maior período de tempo no local contendo conídios (Quintela \& MacCoy, 1998). Considerando o efeito sobre o entomopatógeno, Quintela \& MacCoy (1998), referindo-se a um trabalho previamente desenvolvido pelo primeiro autor, observaram que certos componentes da formulação do imidacloprid estimularam a taxa e quantidade de germinação de conídios de $B$. bassiana e $M$. anisopliae na cutícula do inseto hospedeiro, consequentemente, aumentando a infecção pelo patógeno. Pesquisas minuciosas podem evidenciar outros efeitos dos produtos químicos sobre o hospedeiro e/ou entomopatógeno que estejam relacionados ao sinergismo entre ambos, por exemplo: o efeito do produto químico sobre o sistema de defesa dos artrópodos contra o entomopatógeno. O uso de concentrações subletais (subconcentrações) é uma estratégia que permite reduzir a quantidade e o custo com o inimigo natural, a quantidade de resíduos químicos sobre os alimentos e a possibilidade de intoxicação dos trabalhadores rurais durante os processos de preparo da calda inseticida e sua aplicação. 
Neste estudo, foi possível selecionar 24 inseticidas e/ou acaricidas pertencentes a diferentes grupos químicos, para futuros testes que permitam sua utilização em subconcentrações com este entomopatógeno, para o controle das principais pragas que ocorrem em ambiente protegido no Brasil.

Estudos da toxicidade de produtos fitossanitários a inimigos naturais como estes, permitem a utilização prática e imediata dos resultados, e também, criam-se novas linhas de trabalho que virão a complementar e viabilizar a utilização destas duas estratégias de controle em um programa de manejo de pragas. Estes resultados suprimem algumas lacunas que limitam o desenvolvimento deste tipo de programa no país, como forma de tornar o sistema de produção de culturas hortícolas mais eficiente e saudável, e assim, trazer benefícios aos seus produtores e consumidores. 
Tabela 7. Toxicidade de formulações de produtos fitossanitários utilizados em culturas hortícolas no Brasil para Beauveria bassiana, isolado PL63, em condições de laboratório

\begin{tabular}{|c|c|c|c|c|c|c|c|}
\hline Produto Comercial & Nome Técnico & $\begin{array}{c}\text { Concentração } \\
\text { (pc/100 L) }\end{array}$ & Classe & $\begin{array}{c}\text { Grupo } \\
\text { Químico }\end{array}$ & $\begin{array}{c}\text { Classe } \\
\text { Toxicológica }\end{array}$ & Valor de T & $\begin{array}{c}\text { Classificação } \\
\text { do produto }\end{array}$ \\
\hline Carbax & dicofol + tetradifon & $833 \mathrm{ml}$ & A & $\begin{array}{c}\text { Organoclorado + } \\
\text { Clorodifenilsulfona }\end{array}$ & II & 2,61 & Muito tóxico \\
\hline Hokko Cyhexatin 500 & cyhexatin & $50 \mathrm{~g}$ & $\mathrm{~A}$ & Organoestânico & III & 1,89 & Muito tóxico \\
\hline Kelthane 480 & dicofol & $750 \mathrm{ml}$ & A & Organoclorado & II & 4,13 & Muito tóxico \\
\hline Kendo 50 SC & fenpyroximate & $200 \mathrm{ml}$ & $\mathrm{A}$ & Derivado do Pyrazol & II & 60,69 & Compatível \\
\hline Omite 720 CE BR & propargite & $50 \mathrm{ml}$ & $\mathrm{A}$ & $\begin{array}{l}\text { Derivado do Fenoxi } \\
\text { ciclohexil }\end{array}$ & II & 50,15 & Moder. tóxico \\
\hline Ortus $50 \mathrm{SC}$ & fenpyroximate & $200 \mathrm{ml}$ & A & Derivado do Pyrazol & II & 67,04 & Compatível \\
\hline Sanmite & pyridaben & $75 \mathrm{ml}$ & A & Piridazinona & I & 5,23 & Muito tóxico \\
\hline Sipcatin 500 SC & cyhexatin & $50 \mathrm{ml}$ & A & Organoestânico & III & 1,53 & Muito tóxico \\
\hline Tedion 80 & tetradifon & $300 \mathrm{ml}$ & $\mathrm{A}$ & Clorodifenilsulfona & III & 33,29 & Tóxico \\
\hline Agral & etilenoxi & $50 \mathrm{ml}$ & $\mathrm{E}$ & Alquilfenol etoxilado & IV & 17,36 & Muito tóxico \\
\hline Break Thru & $\begin{array}{c}\text { poliéter polimetil } \\
\text { siloxano + poliéter }\end{array}$ & $100 \mathrm{ml}$ & $\mathrm{E}$ & Silicone & IV & 8,94 & Muito tóxico \\
\hline Extravon & $\begin{array}{l}\text { alquil fenol } \\
\text { poliglicol-éter }\end{array}$ & $30 \mathrm{ml}$ & $\mathrm{E}$ & Alquilfenol etoxilato & IV & 17,64 & Muito tóxico \\
\hline Aliette & fosetyl-al & $250 \mathrm{~g}$ & $\mathrm{~F}$ & $\begin{array}{l}\text { Monoetil fosfite } \\
\text { metálico }\end{array}$ & IV & 0,00 & Muito tóxico \\
\hline Amistar $500 \mathrm{WG}$ & azoxystrobin & $16 \mathrm{~g}$ & $\mathrm{~F}$ & Estrobilurina & IV & 9,42 & Muito tóxico \\
\hline Bayfidan CE & triadimenol & $40 \mathrm{ml}$ & $\mathrm{F}$ & Triazol & II & 0,00 & Muito tóxico \\
\hline
\end{tabular}


Tabela 7. Toxicidade de formulações de produtos fitossanitários utilizados em culturas hortícolas no Brasil para Beauveria bassiana, isolado PL63, em condições de laboratório (Continuação)

\begin{tabular}{|c|c|c|c|c|c|c|c|}
\hline Produto Comercial & Nome Técnico & $\begin{array}{c}\text { Concentração } \\
\text { (pc/100 L) }\end{array}$ & Classe & $\begin{array}{c}\text { Grupo } \\
\text { Químico }\end{array}$ & $\begin{array}{c}\text { Classe } \\
\text { Toxicológica }\end{array}$ & Valor de T & $\begin{array}{c}\text { Classificação } \\
\text { do produto }\end{array}$ \\
\hline Benlate 500 & benomyl & $70 \mathrm{~g}$ & $\mathrm{~F}$ & Benzimidazol & III & 0,00 & Muito tóxico \\
\hline Captan 500 PM & captan & $240 \mathrm{~g}$ & $\mathrm{~F}$ & Derivado da Ftalimida & III & 0,00 & Muito tóxico \\
\hline Cercobin 700 PM & tiofanato metílico & $70 \mathrm{~g}$ & $\mathrm{~F}$ & Benzimidazol & IV & 0,00 & Muito tóxico \\
\hline Cerconil PM & $\begin{array}{c}\text { clorotalonil }+ \\
\text { tiofanato metílico }\end{array}$ & $200 \mathrm{~g}$ & $\mathrm{~F}$ & $\begin{array}{l}\text { Derivado da } \\
\text { Ftalonitrila }+ \\
\text { Benzimidazol }\end{array}$ & II & 0,00 & Muito tóxico \\
\hline Curzate $M+Z i n c o$ & cymoxanil + maneb & $200 \mathrm{~g}$ & $\mathrm{~F}$ & $\begin{array}{c}\text { Acetamida }+ \\
\text { Ditiocarbamato }\end{array}$ & III & 0,00 & Muito tóxico \\
\hline Daconil 500 & clorotalonil & $300 \mathrm{ml}$ & $\mathrm{F}$ & $\begin{array}{l}\text { Derivado da } \\
\text { Ftalonitrila }\end{array}$ & I & 15,50 & Muito tóxico \\
\hline Dacostar 750 & clorotalonil & $200 \mathrm{~g}$ & $\mathrm{~F}$ & $\begin{array}{l}\text { Derivado da } \\
\text { Ftalonitrila }\end{array}$ & II & 15,70 & Muito tóxico \\
\hline Derosal 500 SC & carbendazin & $100 \mathrm{ml}$ & $\mathrm{F}$ & Benzimidazol & III & 0,00 & Muito tóxico \\
\hline Dithiobin 780 PM & $\begin{array}{c}\text { mancozeb + tiofanato } \\
\text { metílico }\end{array}$ & $250 \mathrm{~g}$ & $\mathrm{~F}$ & $\begin{array}{c}\text { Ditiocarbamato + } \\
\text { Benzimidazol }\end{array}$ & II & 0,00 & Muito tóxico \\
\hline Folicur $200 \mathrm{CE}$ & tebuconazole & $100 \mathrm{ml}$ & $\mathrm{F}$ & Triazol & III & 0,00 & Muito tóxico \\
\hline Folpan 500 PM & folpet & $280 \mathrm{~g}$ & $\mathrm{~F}$ & Ftalimida & IV & 5,76 & Muito tóxico \\
\hline Metiltiofan & tiofanato metílico & $90 \mathrm{~g}$ & $\mathrm{~F}$ & Benzimidazol & IV & 0,00 & Muito tóxico \\
\hline Mythos & pyrimethanil & $300 \mathrm{ml}$ & $\mathrm{F}$ & Anilinopiridina & III & 0,00 & Muito tóxico \\
\hline Orthocide 500 & captan & $240 \mathrm{~g}$ & $\mathrm{~F}$ & Ftalimida & III & 0,00 & Muito tóxico \\
\hline
\end{tabular}


Tabela 7. Toxicidade de formulações de produtos fitossanitários utilizados em culturas hortícolas no Brasil para Beauveria bassiana, isolado PL63, em condições de laboratório (Continuação)

\begin{tabular}{|c|c|c|c|c|c|c|c|}
\hline Produto Comercial & Nome Técnico & $\begin{array}{c}\text { Concentração } \\
\text { (pc/100 L) }\end{array}$ & Classe & $\begin{array}{c}\text { Grupo } \\
\text { Químico }\end{array}$ & $\begin{array}{c}\text { Classe } \\
\text { Toxicológica }\end{array}$ & Valor de T & $\begin{array}{c}\text { Classificação } \\
\text { do produto }\end{array}$ \\
\hline Palisade & fluquinconazole & $75 \mathrm{~g}$ & $\mathrm{~F}$ & Triazol & III & 0,00 & Muito tóxico \\
\hline Previcur N & $\begin{array}{l}\text { propamocarb } \\
\text { hidrocloreto }\end{array}$ & $200 \mathrm{ml}$ & $\mathrm{F}$ & Carbamato & IV & 101,61 & Compatível \\
\hline Ridomil-Mancozeb BR & $\begin{array}{c}\text { metalaxyl }+ \\
\text { mancozeb }\end{array}$ & $400 \mathrm{~g}$ & $\mathrm{~F}$ & $\begin{array}{c}\text { Alaninato }+ \\
\text { Ditiocarbamato }\end{array}$ & II & 0,00 & Muito tóxico \\
\hline Rovral & iprodione & $150 \mathrm{~g}$ & $\mathrm{~F}$ & Hidantoína & IV & 3,93 & Muito tóxico \\
\hline Rovral SC & iprodione & $150 \mathrm{ml}$ & $\mathrm{F}$ & Hidantoína & IV & 4,34 & Muito tóxico \\
\hline Rubigan $120 \mathrm{CE}$ & fenarimol & $60 \mathrm{ml}$ & $\mathrm{F}$ & Pirimidina & II & 0,00 & Muito tóxico \\
\hline Sportak $450 \mathrm{CE}$ & procloraz & $100 \mathrm{ml}$ & $\mathrm{F}$ & Imidazolina & $\mathrm{I}$ & 0,00 & Muito tóxico \\
\hline Stroby SC & kresoxim-metil & $40 \mathrm{ml}$ & $\mathrm{F}$ & Strobilurina & III & 10,35 & Muito tóxico \\
\hline Sumilex 500 PM & procimidone & $150 \mathrm{~g}$ & $\mathrm{~F}$ & Dicarboximida & II & 25,58 & Muito tóxico \\
\hline Tattoo C & $\begin{array}{c}\text { propamocarb } \\
\text { hidrocloreto + } \\
\text { clorotalonil }\end{array}$ & $350 \mathrm{ml}$ & $\mathrm{F}$ & $\begin{array}{c}\text { Carbamato + Derivado } \\
\text { da Ftalonitrila }\end{array}$ & I & 36,58 & Tóxico \\
\hline Trifmine & triflumizole & $40 \mathrm{~g}$ & $\mathrm{~F}$ & Imidazol & IV & 0,00 & Muito tóxico \\
\hline Frowncide $500 \mathrm{SC}$ & fluazinam & $100 \mathrm{ml}$ & F/A & Piridinamina & II & 6,70 & Muito tóxico \\
\hline Manzate 800 & mancozeb & $300 \mathrm{~g}$ & F/A & Ditiocarbamato & III & 0,00 & Muito tóxico \\
\hline Dithane PM & mancozeb & $750 \mathrm{~g}$ & F/A & Ditiocarbamato & III & 0,00 & Muito tóxico \\
\hline Kumulus DF & enxofre & $400 \mathrm{~g}$ & F/A & Enxofre & IV & 149,51 & Compatível \\
\hline Cobox & oxicloreto de cobre & $250 \mathrm{~g}$ & $\mathrm{~F} / \mathrm{B}$ & Cúprico & IV & 0,00 & Muito tóxico \\
\hline
\end{tabular}


Tabela 7. Toxicidade de formulações de produtos fitossanitários utilizados em culturas hortícolas no Brasil para Beauveria bassiana, isolado PL63, em condições de laboratório (Continuação)

\begin{tabular}{|c|c|c|c|c|c|c|c|}
\hline Produto Comercial & Nome Técnico & $\begin{array}{c}\text { Concentração } \\
(\text { pc/100 L) }\end{array}$ & Classe & $\begin{array}{c}\text { Grupo } \\
\text { Químico }\end{array}$ & $\begin{array}{c}\text { Classe } \\
\text { Toxicológica }\end{array}$ & Valor de $\mathbf{T}$ & $\begin{array}{c}\text { Classificação } \\
\text { do produto }\end{array}$ \\
\hline Cuprogarb 500 & oxicloreto de cobre & $350 \mathrm{~g}$ & $\mathrm{~F} / \mathrm{B}$ & Cúprico & IV & 0,00 & Muito tóxico \\
\hline Hokko Cupra 500 & oxicloreto de cobre & $300 \mathrm{~g}$ & $\mathrm{~F} / \mathrm{B}$ & Cúprico & IV & 0,00 & Muito tóxico \\
\hline Hokko Kasumin & kasugamycin & $300 \mathrm{ml}$ & $\mathrm{F} / \mathrm{B}$ & Antibiótico & III & 60,43 & Compatível \\
\hline Bulldock 125 SC & betacyflutrin & $10 \mathrm{ml}$ & I & Piretróide & II & 71,81 & Compatível \\
\hline Confidor 700 GRDA & imidacloprid & $30 \mathrm{~g}$ & I & Nitroguanidina & IV & 288,24 & Compatível \\
\hline Cordial 100 & pyriproxyfen & $100 \mathrm{ml}$ & I & Piridil éter & I & 12,47 & Muito tóxico \\
\hline Decis $25 \mathrm{CE}$ & deltametrina & $50 \mathrm{ml}$ & I & Piretróide & III & 78,35 & Compatível \\
\hline Dimilin & diflubenzuron & $50 \mathrm{~g}$ & I & Derivado da uréia & IV & 84,50 & Compatível \\
\hline Dipterex 500 & triclorfon & $300 \mathrm{ml}$ & I & Organofosforado & II & 261,95 & Compatível \\
\hline Elsan & fentoato & $220 \mathrm{ml}$ & I & Organofosforado & I & 3,77 & Muito tóxico \\
\hline Karate $50 \mathrm{CE}$ & lambdacyhalothrin & $50 \mathrm{ml}$ & I & Piretróide & II & 25,52 & Muito tóxico \\
\hline Lannate BR & metomil & $100 \mathrm{ml}$ & I & Carbamato & I & 42,66 & Tóxico \\
\hline Mesurol 500 SC & metiocarb & $150 \mathrm{ml}$ & I & Carbamato & II & 9,34 & Muito tóxico \\
\hline Mimic 240 SC & tebufenozide & $50 \mathrm{ml}$ & I & Diacylhydrazina & IV & 61,46 & Compatível \\
\hline Mospilan & acetamiprid & $25 \mathrm{~g}$ & I & Cloronicotinil & III & 55,96 & Moder. tóxico \\
\hline Provado & imidacloprid & $60 \mathrm{~g}$ & I & Cloronicotinil & IV & 77,61 & Compatível \\
\hline Sumicidin 200 & fenvalerate & $50 \mathrm{ml}$ & I & Piretróide & II & 54,82 & Moder. tóxico \\
\hline Talcord $250 \mathrm{CE}$ & permetrina & $30 \mathrm{ml}$ & I & Piretróide & II & 31,47 & Tóxico \\
\hline Tiger $100 \mathrm{CE}$ & pyriproxyfen & $100 \mathrm{ml}$ & I & Piridil éter & I & 4,50 & Muito tóxico \\
\hline
\end{tabular}


Tabela 7. Toxicidade de formulações de produtos fitossanitários utilizados em culturas hortícolas no Brasil para Beauveria bassiana, isolado PL63, em condições de laboratório (Continuação)

\begin{tabular}{|c|c|c|c|c|c|c|c|}
\hline Produto Comercial & Nome Técnico & $\begin{array}{c}\text { Concentração } \\
\text { (pc/100 L) }\end{array}$ & Classe & $\begin{array}{c}\text { Grupo } \\
\text { Químico }\end{array}$ & $\begin{array}{c}\text { Classe } \\
\text { Toxicológica }\end{array}$ & Valor de $\mathbf{T}$ & $\begin{array}{c}\text { Classificação } \\
\text { do produto }\end{array}$ \\
\hline Trebon $100 \mathrm{SC}$ & etofenprox & $200 \mathrm{ml}$ & I & Arilpropilbenzil eter & IV & 7,39 & Muito tóxico \\
\hline Trigard $750 \mathrm{PM}$ & ciromazina & $15 \mathrm{~g}$ & I & Triazína & IV & 55,79 & Moder. tóxico \\
\hline Turbo & betacyflutrin & $25 \mathrm{ml}$ & I & Piretróide & II & 35,87 & Tóxico \\
\hline Deltaphos CE & $\begin{array}{l}\text { deltametrina }+ \\
\text { triazofós }\end{array}$ & $100 \mathrm{ml}$ & I & $\begin{array}{c}\text { Piretróide }+ \\
\text { Organofosforado }\end{array}$ & I & 8,43 & Muito tóxico \\
\hline Vertimec $18 \mathrm{CE}$ & abamectin & $100 \mathrm{ml}$ & $\mathrm{I} / \mathrm{A}$ & Avermectina & III & 79,07 & Compatível \\
\hline Applaud 250 & buprofezin & $200 \mathrm{~g}$ & $\mathrm{I} / \mathrm{A}$ & Tiadiazina & IV & 25,53 & Muito tóxico \\
\hline Folidol 600 & paration metil & $110 \mathrm{ml}$ & $\mathrm{I} / \mathrm{A}$ & Organofosforado & I & 0,00 & Muito tóxico \\
\hline Lebaycid 500 & fention & $100 \mathrm{ml}$ & $\mathrm{I} / \mathrm{A}$ & Organofosforado & II & 5,11 & Muito tóxico \\
\hline Match CE & lufenuron & $80 \mathrm{ml}$ & $\mathrm{I} / \mathrm{A}$ & Aciluréia & IV & 21,15 & Muito tóxico \\
\hline Sevin 480 SC & carbaril & $225 \mathrm{ml}$ & $\mathrm{I} / \mathrm{A}$ & Carbamato & II & 4,44 & Muito tóxico \\
\hline Sumithion $500 \mathrm{CE}$ & fenitrotion & $200 \mathrm{ml}$ & $\mathrm{I} / \mathrm{A}$ & Organofosforado & II & 0,00 & Muito tóxico \\
\hline Cefanol & acefato & $150 \mathrm{~g}$ & $\mathrm{I} / \mathrm{A}$ & Organofosforado & III & 198,48 & Compatível \\
\hline Danimen $300 \mathrm{CE}$ & fenpropatrina & $15 \mathrm{ml}$ & $\mathrm{I} / \mathrm{A}$ & Piretróide & I & 39,57 & Tóxico \\
\hline Dicarzol 500 PS & $\begin{array}{l}\text { formetanato } \\
\text { hidrocloreto }\end{array}$ & $150 \mathrm{~g}$ & $\mathrm{I} / \mathrm{A}$ & Carbamato & I & 0,00 & Muito tóxico \\
\hline Dimetoato CE Milenia & dimetoato & $125 \mathrm{ml}$ & $\mathrm{I} / \mathrm{A}$ & Organofosforado & I & 29,76 & Muito tóxico \\
\hline Dimexion & dimetoato & $100 \mathrm{ml}$ & $\mathrm{I} / \mathrm{A}$ & Organofosforado & I & 75,81 & Compatível \\
\hline Ethion 500 RPA & etion & $150 \mathrm{ml}$ & $\mathrm{I} / \mathrm{A}$ & Organofosforado & I & 14,75 & Muito tóxico \\
\hline
\end{tabular}


Tabela 7. Toxicidade de formulações de produtos fitossanitários utilizados em culturas hortícolas no Brasil para Beauveria bassiana, isolado PL63, em condições de laboratório (Continuação)

\begin{tabular}{|c|c|c|c|c|c|c|c|}
\hline Produto Comercial & Nome Técnico & $\begin{array}{c}\text { Concentração } \\
(\text { pc/100 L) }\end{array}$ & Classe & $\begin{array}{c}\text { Grupo } \\
\text { Químico }\end{array}$ & $\begin{array}{c}\text { Classe } \\
\text { Toxicológica }\end{array}$ & Valor de $\mathbf{T}$ & $\begin{array}{c}\text { Classificação } \\
\text { do produto }\end{array}$ \\
\hline Hamidop 600 & metamidofós & $100 \mathrm{ml}$ & $\mathrm{I} / \mathrm{A}$ & Organofosforado & I & 119,87 & Compatível \\
\hline Meothrin 300 & fenpropatrina & $65 \mathrm{ml}$ & $\mathrm{I} / \mathrm{A}$ & Piretróide & I & 66,35 & Compatível \\
\hline Ofunack $400 \mathrm{CE}$ & piridafention & $200 \mathrm{ml}$ & $\mathrm{I} / \mathrm{A}$ & Organofosforado & III & 0,00 & Muito tóxico \\
\hline Orthene $750 \mathrm{BR}$ & acefato & $100 \mathrm{~g}$ & $\mathrm{I} / \mathrm{A}$ & Organofosforado & IV & 73,14 & Compatível \\
\hline Polo 500 PM & diafentiuron & $80 \mathrm{~g}$ & $\mathrm{I} / \mathrm{A}$ & Tiouréia & I & 112,89 & Compatível \\
\hline Polytrin 400/40 CE & $\begin{array}{l}\text { cipermetrina }+ \\
\text { profenofós }\end{array}$ & $312,5 \mathrm{ml}$ & $\mathrm{I} / \mathrm{A}$ & $\begin{array}{c}\text { Piretróide }+ \\
\text { Organofosforado }\end{array}$ & II & 3,34 & Muito tóxico \\
\hline Stron & metamidofós & $100 \mathrm{ml}$ & $\mathrm{I} / \mathrm{A}$ & Organofosforado & I & 85,73 & Compatível \\
\hline Talstar $100 \mathrm{CE}$ & bifentrina & $30 \mathrm{ml}$ & $\mathrm{I} / \mathrm{A}$ & Piretróide & II & 49,33 & Moder. tóxico \\
\hline Tamaron BR & metamidofós & $100 \mathrm{ml}$ & $\mathrm{I} / \mathrm{A}$ & Organofosforado & II & 105,89 & Compatível \\
\hline Tiomet $400 \mathrm{CE}$ & dimetoato & $200 \mathrm{ml}$ & $\mathrm{I} / \mathrm{A}$ & Organofosforado & I & 117,85 & Compatível \\
\hline Cartap BR 500 & cartap hidrocloreto & $250 \mathrm{~g}$ & $\mathrm{I} / \mathrm{F}$ & Tiocarbamato & III & 0,00 & Muito tóxico \\
\hline Thiobel 500 & cartap hidrocloreto & $250 \mathrm{~g}$ & $\mathrm{I} / \mathrm{F}$ & Tiocarbamato & III & 0,00 & Muito tóxico \\
\hline
\end{tabular}



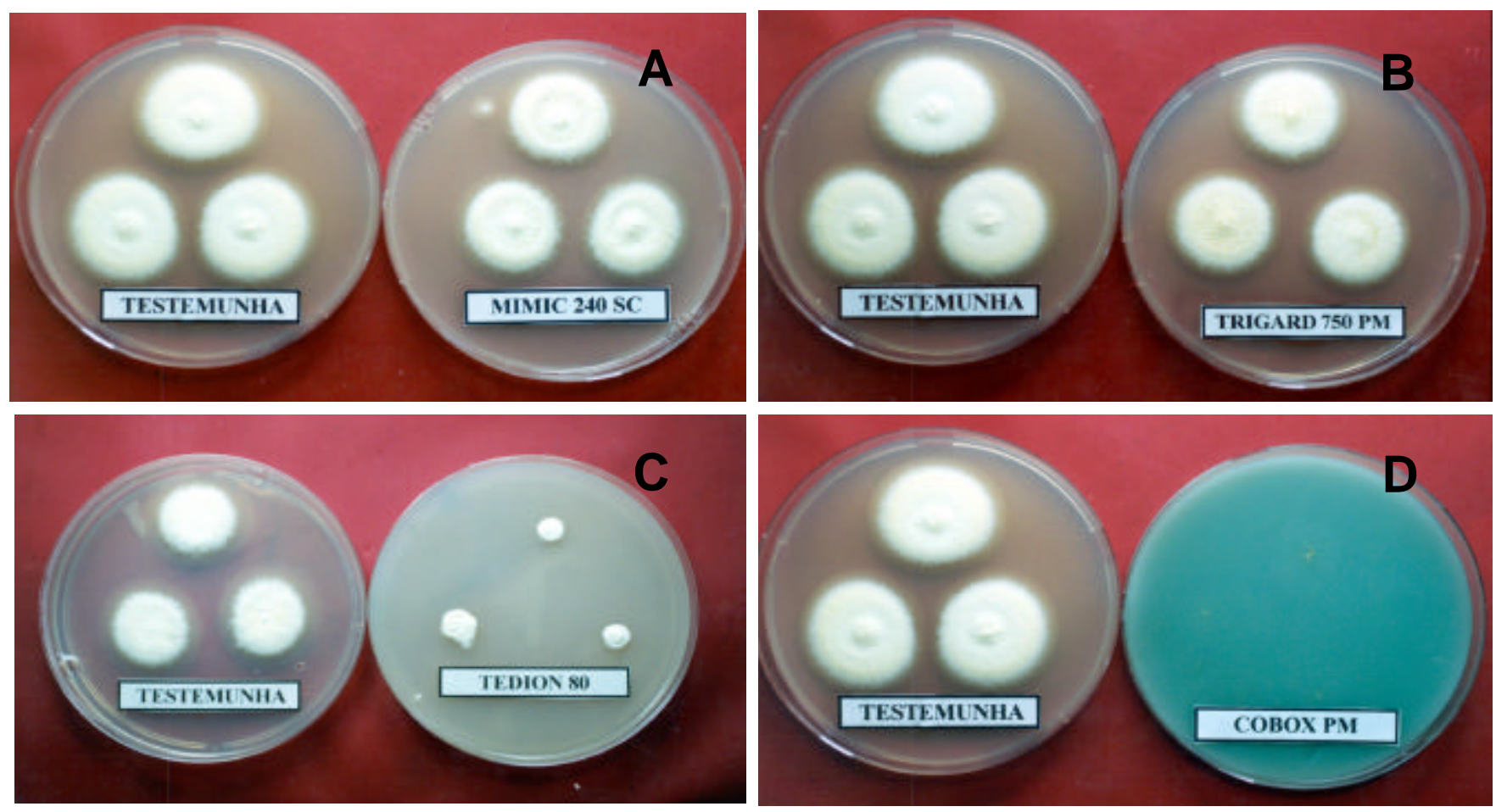

Figura 7 - Crescimento de colônias de Beauveria bassiana, isolado PL63, sob o efeito de formulações de produtos fitossanitários, e sua classificação de toxicidade. A- Compatível; B- Moderadamente Tóxico; C- Tóxico; D- Muito tóxico.

\subsection{Conclusões}

- é possível selecionar produtos fitossanitários compatíveis ao fungo B. bassiana, para uso em programas de MIP e doenças

- uma porcentagem menor de produtos fungicidas são compatíveis com B. bassiana, quando comparados com os inseticidas e/ou acaricidas

- além do ingrediente ativo, outros fatores estão relacionados com a toxicidade de um produto fitossanitários para B. bassiana

- algumas produtos fitossanitários estimulam a produção de conídios por B. bassiana. 


\section{USO DE Beauveria bassiana PARA O CONTROLE DE Tetranychus urticae NAS CULTURAS DO CRISÂNTEMO E MORANGO EM ESTUFA}

\section{Resumo}

Os fungos Beauveria bassiana e Metarhizium anisopliae foram avaliados para o controle de Tetranychus urticae nas culturas do crisântemo de corte (Dendranthema grandiflora Tzvelev) e morango (Fragaria spp.) em ambiente de cultivo protegido. $B$. bassiana quando pulverizada na concentração de $2 \times 10^{8}$ conídios $/ \mathrm{mL}$ foi eficiente no controle de T. urticae no crisântemo, com níveis de controle estatisticamente superiores ao tratamento químico utilizado na propriedade agrícola. Após quatro pulverizações do fungo em um período de 14 dias, a densidade reduziu de 1,8 para 0,1 ácaro/folha. Ácaros mortos apresentando esporulação do entomopatógeno foram vistos sobre as folhas da cultura e quando observados sob lâmina, revelavam a presença de pequenos cristais em seu interior, produzidos durante a fase de colonização pelo entomopatógeno. Na cultura do morango, o controle de T. urticae foi mais eficiente a medida que se aumentou a concentração de B. bassiana na suspensão. A densidade média de ácaros ao longo de 21 dias de avaliação para as concentrações $1 \times 10^{8}$ e $5 \times 10^{7}$ conídios $/ \mathrm{mL}$ de $B$. bassiana foi de 13 ácaros/folíolo, contra 43 ácaros/folíolo nas parcelas não tratadas. As variedades de morango Campinas e Princesa Isabel foram as que apresentaram as menores densidades do ácaro, contudo, não houve evidência de que estas variedades interferiram na eficiência de controle da praga por B. bassiana. O fungo M. anisopliae, na concentração de $1 \times 10^{7}$ conídios/mL, não apresentou qualquer efeito de controle da praga. 
Palavras-chave: Beauveria bassiana, Tetranychus urticae, estufa, controle biológico.

\section{USE OF Beauveria bassiana FOR CONTROL OF Tetranychus urticae IN GREENHOUSE CHRYSANTHEMUM AND STRAWBERRY}

\section{Summary}

The fungi Beauveria bassiana and Metarhizium anisopliae were evaluated for the control of Tetranychus urticae in chrysanthemum (Dendranthema grandiflora Tzvelev) and strawberry (Fragaria spp.) in greenhouses. B. bassiana sprayed at concentration of $2 \times 10^{8}$ conidia/mL was an efficient mite control in chrysanthemum, with control levels higher that those provided by chemical pesticides normally used in the greenhouses. After four fungal sprays within 14 days, the mite density was reduced from 1.8 to 0.1 mite/leaf. The entomopathogen sporulated on the mite cadavers on the plant leaves. Under microscope, crystals were observed inside the infected cadavers. In strawberry, $T$. urticae control increased as B. bassiana concentrations increased. The mean density of mites for 21 days after application of $1 \times 10^{8}$ or $5 \times 10^{7}$ B. bassiana conidia/mL was 13 mites/leaflet, compared to 43 mites/leaflet in control plots. The strawberry varieties "Campinas" and "Princesa Isabel" had the lowest mite densities, however, these varieties did not affect the efficacy of mite control by $B$. bassiana. The fungus $M$. anisopliae, at $1 \times 10^{7}$ conidia/mL, did not control the mite.

Keywords: Beauveria bassiana, Tetranychus urticae, greenhouse, biological control. 


\subsection{Introdução}

A crescente preocupação da sociedade brasileira com relação a qualidade dos alimentos é evidente, e tem se refletido em mudanças de seu comportamento tradicional. Isto é percebido pela valorização daqueles que são produzidos de formas diferenciadas, com técnicas que utilizam nenhuma ou reduzidas quantidades de defensivos agrícolas (FNP, 2001). Um bom exemplo são as culturas olerícolas consumidas de forma "in natura”, que por esta razão, representam maiores riscos à saúde. Inclusive culturas como ornamentais, que apesar de não serem consumidas como alimento, quando comercializadas poucos dias após as últimas pulverizações, podem representar alto risco aos consumidores que manipulam esses produtos sem nenhum tipo de proteção.

O fenômeno da resistência de pragas aos produtos químicos tem incrementado os problemas com resíduos, pois induzem ao aumento das concentrações e frequiências de aplicações destes produtos, além de agravar outros importantes problemas como a intoxicação dos trabalhadores durante o preparo da calda e aplicação. Estes problemas têm sido mais graves em cultivos protegidos (estufas). Nestes locais as condições ambientais são mais favoráveis ao desenvolvimento de resistência, a degradação dos produtos químicos é mais lenta do que em campo aberto e, também, porque a circulação do ar é reduzida. Neste último caso, a intoxicação dos trabalhadores ocorre pela inalação de vapores produzidos pelos produtos químicos durante e após sua aplicação, especialmente nos horários mais quentes do dia.

Esta situação tem exigido uma reavaliação do sistema de produção de muitas culturas, e têm demandado pesquisas por métodos não químicos de controle de insetos e ácaros praga. Neste sentido, o controle microbiano, pela utilização de fungos como Beauveria bassiana, Metarhizium anisopliae, Verticillium lecanii, Hirsutella thompsonii e Paecilomyces fumosoroseus pode representar uma prática viável dentro de um programa de Manejo Integrado de Pragas (MIP) em culturas hortícolas no país. Estes fungos apresentam características importantes que os tornam adequados para formulação como biopesticidas, como por exemplo: não causam fitotoxicidade; são adequados para

o manejo da resistência; não representam risco a saúde dos usuários e consumidores; não 
exigem período de carência; apresentam amplo espectro de ação; são de fácil produção e aplicação (Alves, 1998b). Contudo, a eficiência destes inimigos naturais é muito dependente de condições ambientais favoráveis como alta umidade relativa do ar, temperaturas moderadas e baixa incidência de radiação ultravioleta (Alves \& Lecuona, 1998). Neste sentido, as estufas oferecem grande oportunidade para o uso destes entomopatógenos, pois suas condições ambientais podem ser manipuladas de forma a favorecer os entomopatógenos, controlando-se a abertura e fechamento das cortinas superiores e laterais, uso de sombrites, filmes plásticos com aditivos capazes de filtrar a radiação ultravioleta e o manejo da irrigação.

Atualmente, formulações comerciais de B. bassiana Botanigard $^{\circledR}$, $^{\text {Mycotrol }}{ }^{\circledR}$ WP, Naturalis-L ${ }^{\circledR}$ e BEA-SIN $\left.{ }^{\circledR}\right), V$. lecanii $\left(\right.$ Mycotal $^{\circledR}$ e Vertalec $\left.{ }^{\circledR}\right)$ e P. fumosoroseus $\left(\right.$ PAE-SIN $\left.{ }^{\circledR}\right)$ são comercializadas na Europa, Estados Unidos, e alguns países da América Latina e Caribe para o controle de pragas em campo aberto e cultivos protegidos (Shannon, 1996). No Brasil, existem duas formulações comerciais disponíveis aos produtores Boveril ${ }^{\circledR}$ PM (B. bassiana) e Metarril ${ }^{\circledR}$ PM (M. anisopliae), cujos testes em laboratório e campo comprovam suas eficiências no controle de Tetranychus urticae (Acari: Tetranychidae), Bemisia tabaci (Sternorrhyncha: Aleyrodidae) e Frankliniella occidentalis (Thysanoptera: Thripidae) (Tamai, 1998; Lopes, 1999; Alves et al., 2001b), pragas-chave de muitas culturas hortícolas cultivadas no país (Oliveira, 1995).

O presente trabalho teve como objetivo comparar a eficiência dos fungos $B$. bassiana e M. anisopliae com o controle químico, na redução da população do ácaro $T$. urticae nas culturas do crisântemo de corte (Dendranthema grandiflora Tzvelev) e morango (Fragaria spp.) em ambiente de cultivo protegido. 


\subsection{Material e Métodos}

\subsubsection{Controle de $T$. urticae na cultura do crisântemo de corte}

O teste foi desenvolvido na fazenda Ribeirão, no município de Holambra-SP, no período de abril a maio de 1998, em estufa com cobertura plástica contendo canteiros de matrizes de crisântemo de corte, D. grandiflora (Figuras 8A e 8B). As plantas apresentavam entre 30 e $40 \mathrm{~cm}$ de altura em sistema de plantio adensado e a infestação da cultura pela praga ocorreu naturalmente. A cultura foi irrigada diariamente durante 20 minutos, no início da noite, utilizando-se o sistema por aspersão. As lâminas de água utilizadas nas irrigações não foram determinadas, contudo, foram sempre suficientes para suprir a exigência da cultura, constatada pela boa turgidez das plantas.

Os tratamentos avaliados foram: 1) B. bassiana isolado PL63 na concentração de $2 \times 10^{8}$ conídios/mL; 2) controle químico utilizado pelo produtor; 3) testemunha que recebeu apenas água mais espalhante adesivo (Tween $80^{\circledR}-0,2 \mathrm{~mL} / \mathrm{L}$ ). Cada tratamento foi representado por oito parcelas, cada uma constituída por 5 metros lineares de canteiro com 1 metro de largura, totalizando $5 \mathrm{~m}^{2}$. Os canteiros foram separados entre si por um carreador sem plantas de $50 \mathrm{~cm}$ de largura, e as parcelas separadas entre si na linha por $2 \mathrm{~m}$ lineares de canteiro contendo plantas que não receberam pulverizações. $\mathrm{O}$ delineamento experimental utilizado foi o de parcelas inteiramente casualizadas.

O fungo B. bassiana (PL63) foi isolado de operária de Atta sp. (Hymenoptera: Formicidae) em Piracicaba-SP, e encontra-se armazenado no Banco de Isolados do Laboratório de Patologia e Controle Microbiano de Insetos da ESALQ/USP, em freezer a $-12^{\circ} \mathrm{C}$ na forma de conídios puros. 

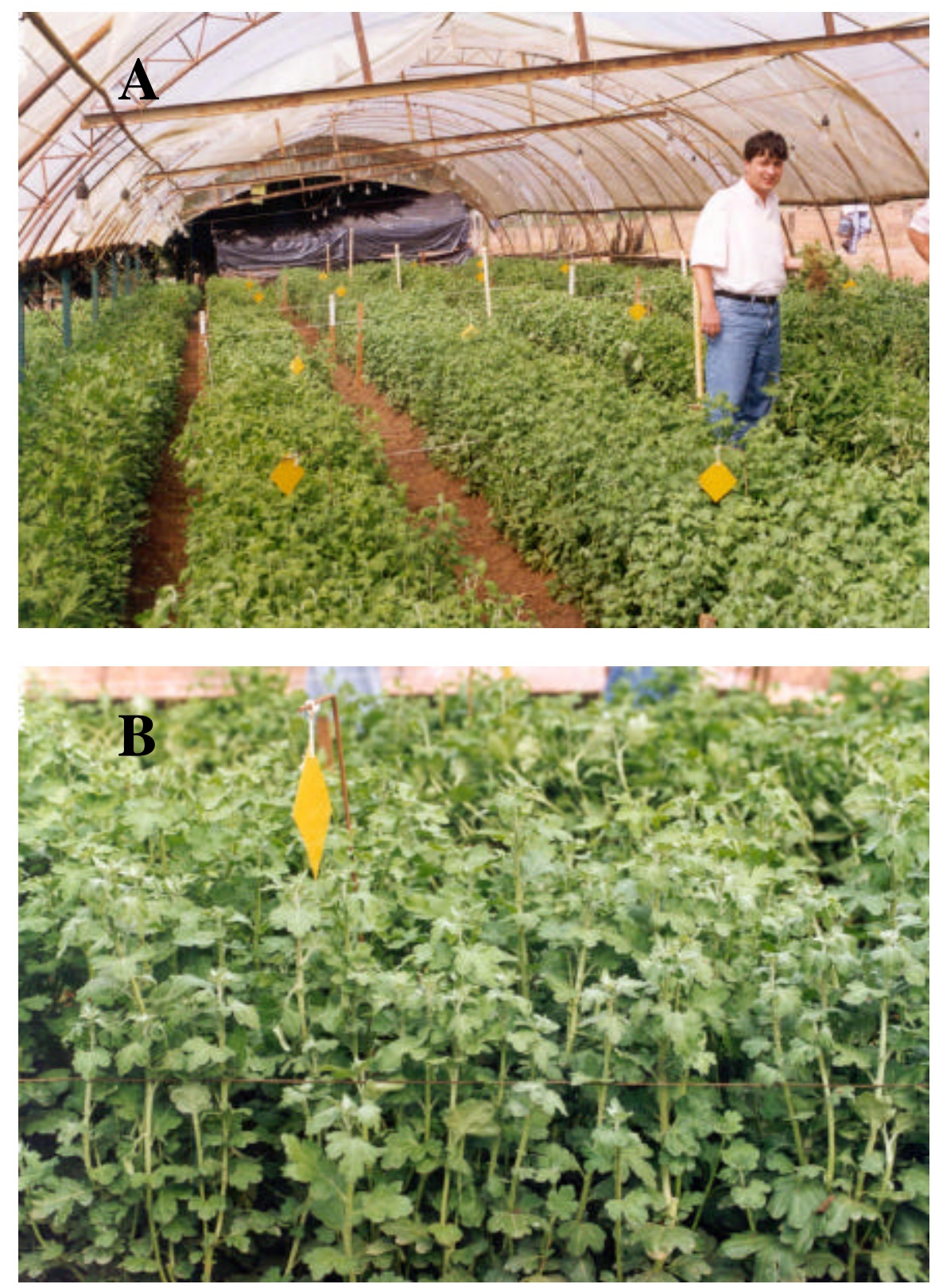

Figura 8 - A) Estufa contendo os canteiros de matrizes de crisântemo e parcelas experimentais; B) Plantas de crisântemo em cultivo adensado.

Os conídios de B. bassiana, apresentando $98 \%$ de viabilidade, foram produzidos em bandejas plásticas sobre arroz pré-cozido (Alves \& Pereira, 1989), e as suspensões preparadas misturando-se o fungo em água com espalhante adesivo $(0,01 \%)$. 
Para a preparação da suspensão de conídios, $50 \mathrm{~g}$ de arroz pré-cozido com fungo foi inicialmente colocado dentro de uma garrafa de vidro de $500 \mathrm{~mL}$ contendo $200 \mathrm{~mL}$ de água estéril mais espalhante adesivo (Tween $80^{\circledR}-0,2 \mathrm{~mL} / \mathrm{L}$ ). A garrafa foi então agitada sendo a suspensão resultante filtrada em um tecido de malha fina para a separação dos conídios de B. bassiana da massa de grãos. Esta suspensão foi então acondicionada em um béquer graduado de plástico, e o seu volume completado para 2,5 litros com água mais espalhante adesivo, produzindo-se assim uma suspensão com $2 \times 10^{8}$ conídios $/ \mathrm{mL}$, suficiente para a pulverização de uma parcela do tratamento. $\mathrm{O}$ controle químico, consistiu no procedimento padrão da propriedade agrícola para o controle fitossanitário da cultura, sendo representado por duas a três pulverizações semanais de uma mistura contendo inseticida, acaricida, fungicida, espalhante adesivo e adubo foliar em diferentes combinações (Tabela 8).

As pulverizações das parcelas foram feitas utilizando-se dois sistemas: 1) para o tratamento químico, foi utilizado o equipamento da propriedade, que consistiu em uma barra de metal contendo 4 bicos pulverizadores, em alto volume, consumindo entre 200 e 300 litros/hectare; 2) nas parcelas testemunha e com PL63 foram pulverizados 2,5 litros do tratamento/parcela utilizando-se um atomizador costal motorizado Jacto, modelo PL50BV, com o jato dirigido para a face inferior das folhas. As pulverizações foram realizadas durante o período da manhã nas parcela do tratamento químico, e entre às 16 e 17:00 horas para os demais tratamentos. Neste segundo caso, o momento das pulverizações correspondeu a um período de 1 a 2 horas antes do início das irrigações diárias. No final da tarde as temperaturas eram mais amenas, mais favoráveis à infecção dos ácaros pelo entomopatógeno.

Foram feitas seis pulverizações do entomopatógeno e testemunha $(0,4,7,11$, 14 e 18 dias do início do experimento) e nove do "coquetel” químico $(1,5,9,11,14,18$, 21, 25 e 28 dias do início do experimento) com intervalos de 3 a 4 dias entre uma e outra. Em toda a área experimental as aplicações de fungicidas, inseticidas e acaricidas foram suspensas sete dias antes do início dos trabalhos, para recuperação da população dos ácaros e degradação de parte dos resíduos destes produtos sobre e dentro das plantas. 
Tabela 8. Relação de produtos utilizados no tratamento químico e programa de utilização

\begin{tabular}{|c|c|c|c|c|c|c|c|c|c|c|c|}
\hline \multirow{2}{*}{ Produto comercial } & \multirow{2}{*}{ Nome Técnico } & \multirow{2}{*}{ Classe $^{*}$} & \multicolumn{9}{|c|}{ Dias após o início do experimento } \\
\hline & & & 1 & 5 & 9 & 11 & 14 & 18 & 21 & 25 & 28 \\
\hline Acaristop $500 \mathrm{SC}$ & clofentezine & A & & $\mathrm{x}$ & & & & & & & \\
\hline Sanmite & pyridaben & A & & & & & & $\mathrm{x}$ & $\mathrm{x}$ & & \\
\hline Savey PM & hexythiazox & A & & & & & $\mathrm{x}$ & & & & \\
\hline Tedion 80 & tetradifon & A & $\mathrm{x}$ & & & & & & & $\mathrm{x}$ & $\mathrm{x}$ \\
\hline Thiovit Sandoz & enxofre & A & $\mathrm{x}$ & & & & & & & & \\
\hline Torque $500 \mathrm{SC}$ & oxido de fenbutatina & A & & & & & & & & $\mathrm{x}$ & $\mathrm{x}$ \\
\hline Aminosan & - & Adubo & & $\mathrm{x}$ & & $\mathrm{x}$ & & $\mathrm{x}$ & & $\mathrm{x}$ & \\
\hline Extravon & alquil fenol poliglic. & $\mathrm{E}$ & $\mathrm{x}$ & $\mathrm{x}$ & $\mathrm{x}$ & $\mathrm{x}$ & $\mathrm{x}$ & $\mathrm{x}$ & $\mathrm{x}$ & $\mathrm{x}$ & $\mathrm{x}$ \\
\hline Folicur PM & tebuconazole & $\mathrm{F}$ & & & & & & $\mathrm{x}$ & & & \\
\hline Folpan 500 PM & folpet & $\mathrm{F}$ & $\mathrm{x}$ & & & & & & $\mathrm{x}$ & & \\
\hline Isatalonil & clorotalonil & $\mathrm{F}$ & & & & & & & & & $\mathrm{x}$ \\
\hline Kumulus DF & enxofre & F/A & $\mathrm{x}$ & & & & & & & & \\
\hline Persist SC & mancozeb & F/A & & & & & $\mathrm{x}$ & & & & \\
\hline Recop & oxicloreto de cobre & $\mathrm{F} / \mathrm{B}$ & & & $\mathrm{x}$ & & & & & & \\
\hline Rhodiauram SC & thiram & $\mathrm{F}$ & & $\mathrm{x}$ & & & & & & & \\
\hline Saprol & triforine & $\mathrm{F}$ & & & & & & & & $\mathrm{x}$ & \\
\hline Tilt & propiconazole & $\mathrm{F}$ & & & & $\mathrm{x}$ & & & & & \\
\hline Confidor 700 GRDA & imidacloprid & I & & & $\mathrm{x}$ & & & & & & \\
\hline Decis $25 \mathrm{CE}$ & deltametrina & I & & & & $\mathrm{x}$ & & & & & \\
\hline Lannate BR & metomil & I & & & & & & & & $\mathrm{x}$ & \\
\hline Piredan & permetrina & I & & & & & $\mathrm{x}$ & & & & \\
\hline Sevin $480 \mathrm{SC}$ & carbaril & $\mathrm{I}$ & $\mathrm{x}$ & & & & & & & & $\mathrm{x}$ \\
\hline Dimexion & dimetoato & $\mathrm{I} / \mathrm{A}$ & & & & & & $\mathrm{x}$ & & & \\
\hline Hostathion $400 \mathrm{BR}$ & tiazofós & $\mathrm{I} / \mathrm{A}$ & & & & & & $\mathrm{x}$ & $\mathrm{x}$ & & \\
\hline Perfekthion & dimetoato & $\mathrm{I} / \mathrm{A}$ & & & & & & & $\mathrm{x}$ & & \\
\hline Polo 500 PM & diafentiuron & $\mathrm{I} / \mathrm{A}$ & & $\mathrm{x}$ & $\mathrm{x}$ & & & & & & \\
\hline Thiodan CE & endossulfan & $\mathrm{I} / \mathrm{A}$ & & $\mathrm{x}$ & & & & & & & \\
\hline Vertimec $18 \mathrm{CE}$ & abamectin & $\mathrm{I} / \mathrm{A}$ & & & & $\mathrm{x}$ & $\mathrm{x}$ & & & & \\
\hline Total $* *$ & & & 6 & 6 & 4 & 5 & 5 & 6 & 5 & 6 & 5 \\
\hline
\end{tabular}


As avaliações foram realizadas uma vez por semana durante 28 dias, coletando-se, aleatoriamente, três plantas por parcela. Estas plantas eram colocadas em sacos de papel e levadas para o laboratório dentro de uma caixa de isopor contendo gelo, para a quantificação dos ácaros presentes em quinze folhas/planta retiradas dos terços apical e mediano das mesmas. O número médio de ácaros ao longo dos 28 dias foi analisado utilizando-se a regressão polinomial $(\mathrm{P} \leq 0,05)$, enquanto as demais médias foram submetidas ao Teste de Tukey $(\mathrm{P} \leq 0,05)$.

\subsubsection{Controle de $T$. urticae na cultura do morango}

O experimento foi conduzido no Departamento de Produção Vegetal da ESALQ/USP em Piracicaba-SP, no período de julho a agosto de 2000, em uma estufa plástica do tipo arco.

O delineamento experimental utilizado foi o de parcelas subdivididas, com três blocos, 7 produtos/inseticidas (fator parcela) e 5 variedades de morango Fragaria spp. (fator subparcela). As plantas foram produzidas em vasos plásticos de polietileno na densidade de uma planta por vaso, contendo como substrato uma mistura de terra, areia e esterco bovino. Os vasos foram mantidos a $80 \mathrm{~cm}$ do solo, sobre bancadas feitas de ripas de madeira intercaladas com um pequeno espaço vazio, a fim de permitir o escorrimento da água e evitar seu acúmulo próximo aos vasos, o que predispõe às plantas ao ataque de doenças. Ao longo de seu desenvolvimento, as plantas foram irrigadas diariamente pelo sistema de espaguetes e adubadas de acordo com as recomendações técnicas para a cultura. A infestação da cultura pela praga ocorreu naturalmente.

Os tratamentos nas parcelas foram: a-d) B. bassiana (isolado PL63) nas concentrações de $5 \times 10^{6}, 1 \times 10^{7}, 5 \times 10^{7}$ e $1 \times 10^{8}$ conídios $/ \mathrm{mL}$; e) B. bassiana (isolado CB66) na concentração de $1 \times 10^{7}$ conídios/mL; f) M. anisopliae (isolado 1037) na concentração de $1 \times 10^{7}$ conídios/mL; g) Vertimec $18 \mathrm{CE}$ (Abamectin) na dose de $50 \mathrm{~mL}$ p.c./100 litros; h) testemunha, que recebeu apenas água destilada com espalhante 
adesivo (Tween $80^{\circledR}$ - 0,2 mL/L). A produção dos conídios e preparo das suspensões foram realizados com a mesma metodologia descrita no teste com o crisântemo. Os tratamentos nas subparcelas foram as variedades de morango Sequóia, Dover, Firne, Campinas e Princesa Isabel. Cada parcela experimental consistiu de 15 vasos, sendo três vasos de cada variedade, recebendo as pulverizações do mesmo tratamento. Os fungos 1037 e CB66 foram isolados de Solenopsis sp. (Hymenoptera: Formicidae) e Hypothenemus hampei (Coleoptera: Scolitidae), respectivamente. O primeiro encontrase armazenado nas mesmas condições e local referidos para o isolado PL63, enquanto que o segundo, encontra-se depositado no Banco de Microrganismos Entomopatógenos do Instituto Biológico de São Paulo.

Foram realizadas 6 pulverizações dos tratamentos, sendo a primeira no dia do levantamento populacional e as demais após 4, 7, 11, 14 e 18 dias. As pulverizações foram feitas utilizando um pulverizador costal manual Jacto adaptado com pressão proporcionada por $\mathrm{CO}_{2}$ (15lb.), dirigindo-se o jato de saída do equipamento para a face inferior das folhas.

Foram realizadas 4 avaliações, sendo a primeira o levantamento populacional, e as demais após 7, 14 e 21 dias. As amostras consistiram de 3 folíolos por subparcela (variedade de morango), coletadas ao acaso do terço mediano das plantas. As folhas foram acondicionadas em sacos de papel e levadas ao laboratório dentro de caixa de isopor com gelo, para a quantificação do número de ácaros em cada folha.

O número médio de ácaros ao longo dos 21 dias foi analisado utilizando-se a regressão polinomial ( $\mathrm{P} \leq 0,05)$, enquanto as demais média foram submetidas ao Teste de Tukey $(\mathrm{P} \leq 0,05)$. 


\subsection{Resultados e Discussão}

\subsubsection{Controle de $T$. urticae na cultura do crisântemo de corte}

O estudo estatístico dos tratamentos (testemunha, químico e B. bassiana) e dos momentos de avaliação $(0,7,14,21$ e 28 dias do início do experimento) demonstrou que existe interação significativa entre estes, para a densidade de $T$. urticae por folha de crisântemo (P $\leq 0,01)$ (Tabela 9). A partir deste estudo, foi determinada as equações de regressão para os três tratamentos e suas linhas de tendências foram representadas graficamente na Figura 9.

Pela análise da variância constatou-se que, em média e ao longo dos 28 dias, existiu diferença significativa entre os tratamentos quanto ao número de ácaros. Neste caso, cada tratamento foi diferente dos demais (Tabela 10).

Tabela 9. Análise de variância para tratamentos (testemunha, químico e Beauveria bassiana) e momentos de avaliação $(0,7,14,21$ e 28 dias do início do experimento)

\begin{tabular}{lccccc}
\hline Tratamento & G.L. & S.Q. & Q.M. & Valor de “F”' & Prob.>F \\
\hline Tratamento & 2 & 211,24 & 105,62 & 99,66 & $0,00001^{* *}$ \\
Tempo & 4 & 47,42 & 11,86 & 11,19 & $0,00001^{* *}$ \\
Tratamento x Tempo & 8 & 97,80 & 12,22 & 11,53 & $0,00001^{* *}$ \\
Resíduo & 105 & 111,28 & 1,06 & & \\
Total & 119 & 467,75 & & & \\
\hline
\end{tabular}

Obs.: Coeficiente de variação $=49,1 \%$.

O comportamento do tratamento testemunha foi o de aumento na densidade populacional do ácaro com o passar dos dias após o início do experimento (Figura 9). Ao longo dos 28 dias de avaliação, sua densidade incrementou consideravelmente, passando de 2,6 para 6,01 ácaros/folha. Contudo, para os demais tratamentos o comportamento foi diferente. Até o $21^{\underline{0}}$ dia para B. bassiana houve queda acentuada na densidade populacional do ácaro e, posteriormente, houve uma tendência de 
crescimento da mesma. A interrupção das pulverizações do entomopatógeno a partir do $18^{0}$ dia e a migração de ácaros vindos dos demais tratamentos contribuíram, provavelmente, para a tendência de crescimento populacional da praga em suas parcelas. Para o tratamento químico, a população de $T$. urticae apresentou um comportamento distinto dos demais tratamentos, com mudanças alternadas na tendência populacional da praga. Houve dois períodos de redução populacional, entre os dias 0-7 e 21-28, intercalados entre si por um período de crescimento populacional, apesar das pulverizações dos químicos terem sido mantidas na mesma frequiência (duas pulverizações semanais) até o final do experimento. Neste caso, fatores como a resistência aos produtos químicos, misturas de produtos incompatíveis e problemas com o equipamento de pulverização da propriedade (desgaste dos bicos pulverizadores, volume de calda, etc.) podem ter sido os responsáveis pela flutuação populacional da praga.

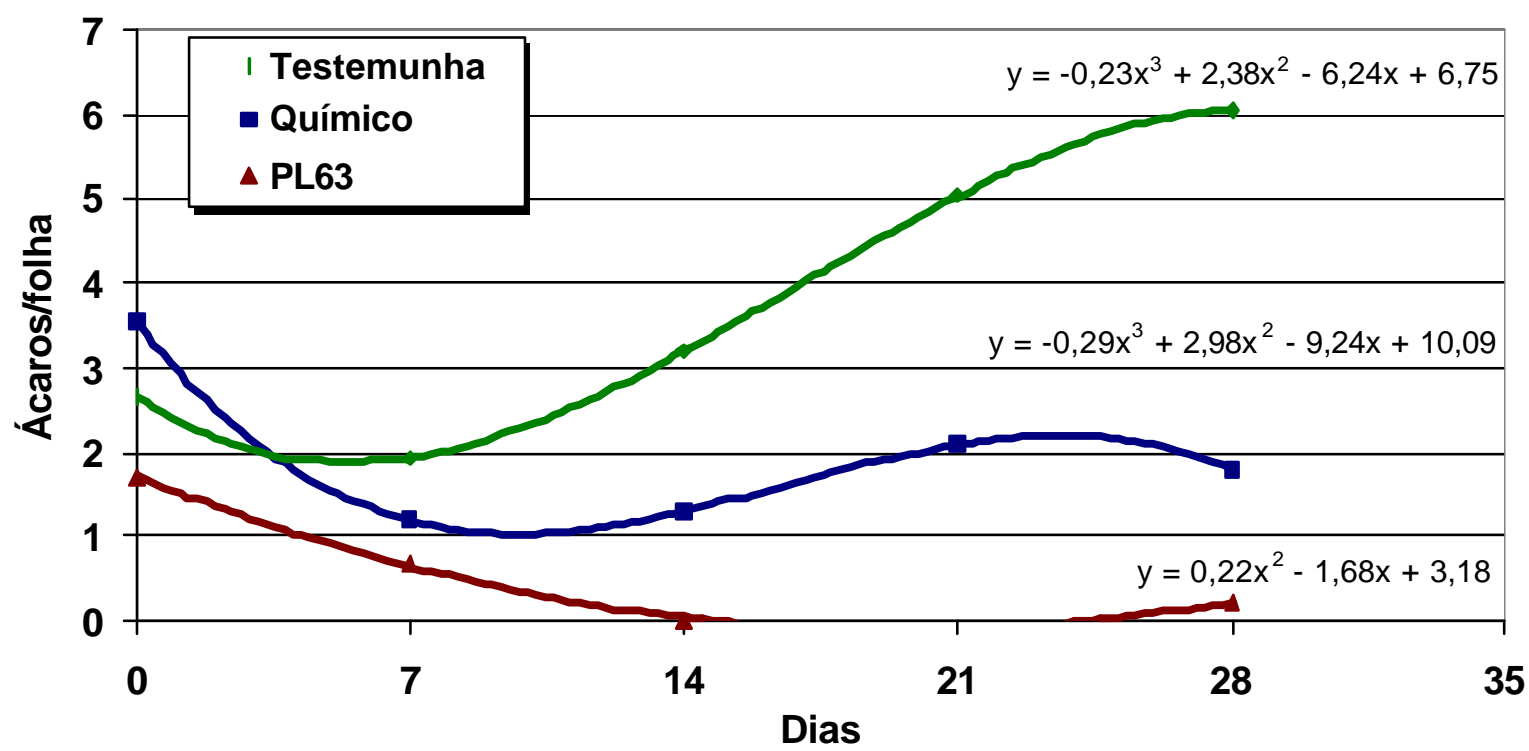

Figura 9 - Densidade populacional de Tetranychus urticae por folha de crisântemo avaliada com $0,7,14,21$ e 28 dias do início do experimento para os tratamentos testemunha, químico e Beauveria bassiana. 
Tabela 10. Densidade média de Tetranychus urticae por folha de crisântemo para os tratamentos (testemunha, químico e Beauveria bassiana) considerando as cinco avaliações $(0,7,14,21$ e 28 dias do início do experimento) conjuntamente

\begin{tabular}{lcccc}
\hline Tratamento & $\begin{array}{c}\text { Número de } \\
\text { repetições }\end{array}$ & $\begin{array}{c}\text { Médias } \\
\text { (ácaros/folha) }\end{array}$ & $\mathbf{5 \%}^{*}$ & $\mathbf{1 \%}^{*}$ \\
\hline Testemunha & 40 & 3,77 & $\mathrm{a}$ & $\mathrm{A}$ \\
Químico & 40 & 1,98 & $\mathrm{~b}$ & $\mathrm{~B}$ \\
PL63 & 40 & 0,53 & $\mathrm{c}$ & $\mathrm{C}$ \\
\hline
\end{tabular}

* Médias seguidas por letras distintas na coluna, diferem entre si ao nível de significância D.M.S. $(5 \%)=0,55$

D.M.S. $(1 \%)=0,68$.

Os valores de eficiência de controle calculados pela fórmula de Henderson \& Tilton (1955) (Tabela 11), apesar de não ter valor estatístico permitem algumas considerações quanto ao nível de controle proporcionado pelos tratamentos químico e $B$. bassiana. Em todas as avaliações, a eficiência do entomopatógeno foi numericamente maior do que o químico. Na avaliação realizada aos 14 dias, sob o efeito de quatro pulverizações dos tratamentos, a eficiência do entomopatógeno foi de aproximadamente $94 \%$, contra $79 \%$ do químico. Nesta avaliação, os números médios de ácaros por folha para estes tratamentos foram de 0,12 e 0,80 respectivamente, contra 2,86 na testemunha. A densidade de ácaros nas parcelas tratadas com o entomopatógeno permaneceu inferior a 0,2 ácaros/folha até o final do experimento, com valores de eficiência de controle sempre superiores a $96 \%$. A maior diferença observada entre os tratamentos foi de $32 \%$ ao $21^{\underline{0}}$ dia.

Estas informações são muito importantes para o estabelecimento de um programa de manejo do ácaro nas áreas de matrizeiros da propriedade com a utilização do isolado PL63 de B. bassiana. As pulverizações de fungicidas devem ser interrompidas ou reduzidas drasticamente por aproximadamente 10 a 14 dias, tempo necessário para o controle esperado do ácaro com o entomopatógeno. A partir deste período, as pulverizações de fungicidas podem ser intensificadas até que a população da praga atinja níveis que sejam necessários novas pulverizações do fungo. Neste trabalho, este período foi de aproximadamente 14 dias, correspondendo ao período em que a 
população do ácaro manteve-se em densidades abaixo de 0,2 ácaros/folha. Contudo, este período é subestimado, pois considera-se apenas os resultados obtidos até a avaliação realizada aos 28 dias. Caso fosse realizada uma avaliação adicional aos 35 dias, é possível que a população do ácaro ainda se mantivesse muito reduzida, não exigindo a reentrada com o inimigo natural. Com a incorporação de estratégias que previnem a reinfestação da área com ácaros vindos de outras estufas da propriedade ou mesmo de outras propriedades agrícolas, este período pode ser aumentado consideravelmente.

Tabela 11. Porcentagem de eficiência de controle (Henderson \& Tilton, 1955) de Tetranychus urticae por Beauveria bassiana (isolado PL63) e químico em canteiros para a produção de mudas de crisântemo no município de Holambra-SP, em 1998

\begin{tabular}{ccccc}
\hline & \multicolumn{4}{c}{ Dias após a início do experimento } \\
\cline { 2 - 5 } & $\mathbf{7}$ & $\mathbf{1 4}$ & $\mathbf{2 1}$ & $\mathbf{2 8}$ \\
\hline Químico & 46,77 & 78,98 & 65,36 & 78,62 \\
B. bassiana & 65,90 & 93,94 & 97,52 & 96,39 \\
\hline
\end{tabular}

O controle de T. urticae pelo isolado PL63 foi também comprovado pela presença de ácaros mortos, com esporulação do entomopatógeno. Estes cadáveres eram encontrados presos aos pêlos das folhas do crisântemo durante as avaliações (Figura 10A), e quando montados sob lâmina em meio Hoyer + azul láctico (1:1) revelavam a presença do conídio e conidióforo característico da espécie e também de pequenos cristais em seu interior. Estes cristais já haviam sido observados para diversos isolados de B. bassiana infectando T. urticae (Tamai \& Alves, dados não publicados), e constituem-se, possivelmente, de oxalato de cálcio ou magnésio (Amaral \& Alves, 1979). Os cristais formam-se durante a colonização do hospedeiro por B. bassiana, pois não são observados até o terceiro dia após a inoculação com o patógeno, período em que predominam as fases de germinação e penetração do fungo no ácaro (Tamai \& Alves, dados não publicados). Durante as avaliações também foram observados, mas não quantificados, pulgões (Figura 10B) e tripes mortos apresentando esporulação do 
entomopatógeno. Estas ocorrências, demonstram o potencial deste isolado para o controle do complexo de pragas que causam danos nesta cultura.

Os bons resultados obtidos neste experimento com $B$. bassiana estão relacionados a pelo menos três fatores: isolado do entomopatógeno; forma de aplicação e condições do ambiente de cultivo. No que se refere ao entomopatógeno, o PL63 foi selecionado por Tamai (1998) entre 105 isolados de Beauveria spp. quanto a patogenicidade a T. urticae e produção de conídios. Esta etapa é de fundamental importância em um programa de controle microbiano, sendo que a variabilidade genética natural destes microrganismos permite selecioná-los quanto às qualidades desejadas para sua utilização como inseticidas/acaricidas microbianos. Algumas destas características incluem a alta eficiência no controle, grande capacidade de disseminação no ambiente, resistência a condições adversas além de qualidades industriais como alta produção de conídios e taxa de crescimento elevada (Frigo \& Azevedo, 1986; Alves, 1986b). Estas características podem existir naturalmente em linhagens selvagens ou serem obtidas pela engenharia genética.

Uma característica interessante e que tem sido trabalhada geneticamente com importantes espécies de fungos entomopatogênicos como B. bassiana, M. anisopliae e P. fumosoroseus é quanto a resistência ao princípio ativo benomyl (Bello \& PaccolaMeirelles, 1998; Furlaneto et al., 1999; Inglis et al., 1999). No Brasil, o produto comercial que contem esta molécula é o Benlate ${ }^{\circledR} 500$, que pertence a classe dos fungicidas sistêmicos do grupo dos benzimidazóis. Este possuí registro para 25 culturas (Andrei, 1999), entre elas algumas que apresentam sérios problemas com T. urticae como o feijão, maçã, morango e tomate (Flechtmann, 1985). A maioria destas culturas também são atacadas por B. tabaci, F. occidentalis, Aphis gossypii e Myzus persicae (Hemiptera: Aphididae) que podem ser controlados pelas mesmas espécies de fungos referidas. Inserir geneticamente esta característica em isolados de fungos com alta patogenicidade a pragas, como o isolado PL63, pode contribuir para sua utilização em culturas que apresentam problemas de doenças foliares, como o tomate, pepino e morango (Kurozawa \& Pavan, 1997ab; Tanaka et al., 1997). Essas culturas necessitam de freqüentes pulverizações de fungicidas químicos, que na maioria das vezes, também 
são tóxicos aos fungos entomopatogênicos (Alves et al., 1998b). É importante considerar a necessidade de incorporação ao sistema de manejo das doenças, outras estratégias de controle como a utilização de mudas sadias, eliminação de plantas hospedeiras, "roguing" (remoção de mudas e plantas doentes), emprego de variedades resistentes, destruição dos restos culturais de plantios anteriores, etc (Jarvis, 1993; Zambolim et al., 1999). Isto porque, a utilização intensiva do benomyl leva ao desenvolvimento de resistência em muitas espécies de fungos fitopatogênicos (Ghini \& Kimati, 2000). Outros fungicidas compatíveis com B. bassiana como o Previcur N (propamocarb hydrochloride), Kumulus DF (enxofre) e Hokko Kasumin (kasugamycin) (Alves et al., 2000; Tabela 14) devem ser utilizados no manejo das doenças como forma de reduzir a pressão de seleção dos fitopatógenos ao benomyl.

No contexto do controle microbiano, o gene que confere a resistência ao benomyl também permite utilizá-lo como um marcador molecular para o uso no monitoramento do entomopatógeno. Isto torna mais eficiente a estimativa de sua eficácia, biosegurança (Inglis et al., 1999) e controle de qualidade dos produtos microbianos comercializados.

O método de aplicação, no que se refere aos equipamentos de pulverização e conhecimento do comportamento das pragas alvo, é de fundamental importância quando se utilizam fungos entomopatogênicos. Estes organismos agem exclusivamente por contato, necessitando que suas estruturas sejam depositadas sobre ou próximas da praga alvo para que possam ser mais eficientes. Em um exame minucioso realizado uma semana antes do início deste experimento, observou-se que a face inferior das folhas do crisântemo era o local de maior concentração dos ácaros nas plantas. Para proporcionar uma boa deposição da suspensão de conídios sobre os ácaros que ai se encontravam foi escolhido o atomizador costal motorizado Jacto, modelo PL50BV, com o jato dirigido para a face inferior das folhas. A velocidade de saída de ar + suspensão de conídios deste equipamento de pulverização permitiu que o entomopatógeno atingisse até mesmo os ácaros que se encontravam nas folhas situadas mais próximas ao solo, por vencer a resistência imposta pela concentração de folhas na parte superior da cultura, especialmente porque o plantio nos canteiros foi feito de forma adensada (Figura 8B). 
Esta situação tornava mais difícil a utilização de outros equipamentos de pulverização, como o costal-manual. A mesma idéia se aplica para o controle de pulgões e ninfas de moscas brancas com fungos entomopatogênicos, pois estas se concentram quase exclusivamente na face inferior das folhas de suas plantas hospedeiras.

O manejo da irrigação adotado na propriedade foi também muito importante para o bom controle de T. urticae por B. bassiana. As irrigações diárias realizadas sobre as plantas no final das tardes/início das noites proporcionavam condições de elevada umidade durante todo a noite e madrugada (aproximadamente 10 horas consecutivas), adequadas para a germinação e penetração dos conídios nos ácaros. O próprio cultivo adensado também permitiu uma maior umidade próximas às plantas, devido a uma menor circulação de ar entre estas. Estudos conduzidos por Vehrs \& Parrella (1991) e Murphy et al. (1998), em laboratório e casa-de-vegetação, demonstraram que a mortalidade de tripes e pulgões pelos produtos comerciais Botanigard $^{\circledR}$ WG (B. bassiana) e Microgermin ${ }^{\circledR}$ (V. lecanii) é incrementada com a umidade relativa do ar. Contudo, a alta umidade relativa do ar por um período prolongado também favorece a ocorrência de fitopatógenos (Bedendo, 1995), sendo este fator um dos que mais limitam a utilização do controle biológico com fungos entomopatogênicos. Neste sentido, Helyer et al. (1992) determinaram que um bom sistema de manejo de pulgões e tripes com V. lecanii em estufa na Europa envolve um período de quatro noites consecutivas de alta umidade relativa por semana. Esta informação suporta os resultados obtidos nesta pesquisa com o isolado PL63.

Considerando-se as exigências de umidade por $V$. lecanii e o sistema de produção de crisântemo, Verhs \& Parrella (1991) mencionaram os bancos de enraizamento e as áreas cobertas por tecido escuro (usado para indução do florescimento) como sendo as áreas mais adequadas para a utilização deste fungo na cultura. Isto porque, durante todo o período para o enraizamento das estruturas vegetativas a freqüência das irrigações é mantida bastante elevada, ao passo que nos locais cobertos por tecido escuro, a redução da circulação de ar resultante proporciona um local com muita umidade. Para o restante da área de produção, quando conduzido em estufas, as condições ambientais de temperatura, umidade relativa e radiação solar 
podem ser manejadas para fornecer condições ótimas aos fungos entomopatogênicos. Estas condições podem ser obtidas pela abertura e/ou fechamento das cortinas laterais e superiores, manejo da irrigação, uso de sombrites, uso de filmes plásticos que retenham a passagem de raios ultravioletas para o interior da estufa. No caso da radiação ultra violeta, esta é capaz de inviabilizar o entomopatógeno presente no local.

O controle químico conduzido na propriedade não se mostrou eficaz no controle de T. urticae mesmo com duas pulverizações semanais. Este fato pode estar relacionado a pelo menos dois fatores. O primeiro consiste aos possíveis efeitos da mistura de diversos produtos na calda de pulverização (inseticida, acaricida, fungicida, espalhante adesivo e adubos minerais) sobre a eficiência destes produtos individualmente. Pela análise da Tabela 8, constata-se que a calda de pulverização continha quase sempre de 5 a 6 produtos químicos diferentes, capazes de suprir as exigências nutricionais da cultura (adubos foliares), e de atingir simultaneamente todo o complexo de doenças foliares e pragas que estavam ocorrendo na propriedade naquela ocasião. Entre as pragas, destacavam-se T. urticae e tripes (provavelmente Frankliniella spp.). Em alguns casos, foram utilizados pelo menos dois princípios ativos recomendados para cada uma destas pragas, como é o caso da pulverização conduzida no $5^{0}$ dia após o início do experimento, quando se utilizaram os produtos Acaristop 500 SC (acaricida), Polo 500 PM e Thiodan CE (acaricida/inseticida). Pode ter ocorrido em algumas situações, o antagonismo dos produtos, reduzindo assim a eficiência de controle das pragas. Porém, investigações minuciosas são necessárias para comprovar esta hipótese. Na visão do produtor da área em questão, a mistura era vista como forma de manejar a resistência das pragas e doenças aos químicos, pela estratégia do ataque múltiplo, e também pelo aspecto operacional, neste caso, para se economizar tempo e dinheiro com mão-de-obra (aplicadores).

O segundo fator está relacionado ao desenvolvimento de resistência na população do ácaro. As próprias características do sistema de produção desta cultura também contribuem para um acelerado desenvolvimento da resistência. O crisântemo é cultivado continuamente ao longo dos anos no mesmo local, com pelo menos 3 ciclos de produção/anual, fazendo com que a pressão de seleção seja imposta ao longo de todo 
um ano. Além disso, o próprio fato das estufas limitarem a entrada de indivíduos suscetíveis vindos de fora (através da migração), acelera todo o processo de desenvolvimento da resistência. As exigências do mercado consumidor por produtos sem a presença ou sintomas de organismos indesejados (insetos, ácaros e fitopatógenos) faz com que o controle destes organismos seja feito de forma preventiva ou mesmo quando o nível de infestação esteja ainda muito baixo, contribuindo para agravar os problemas com a resistência (Van de Vrie, 1985).
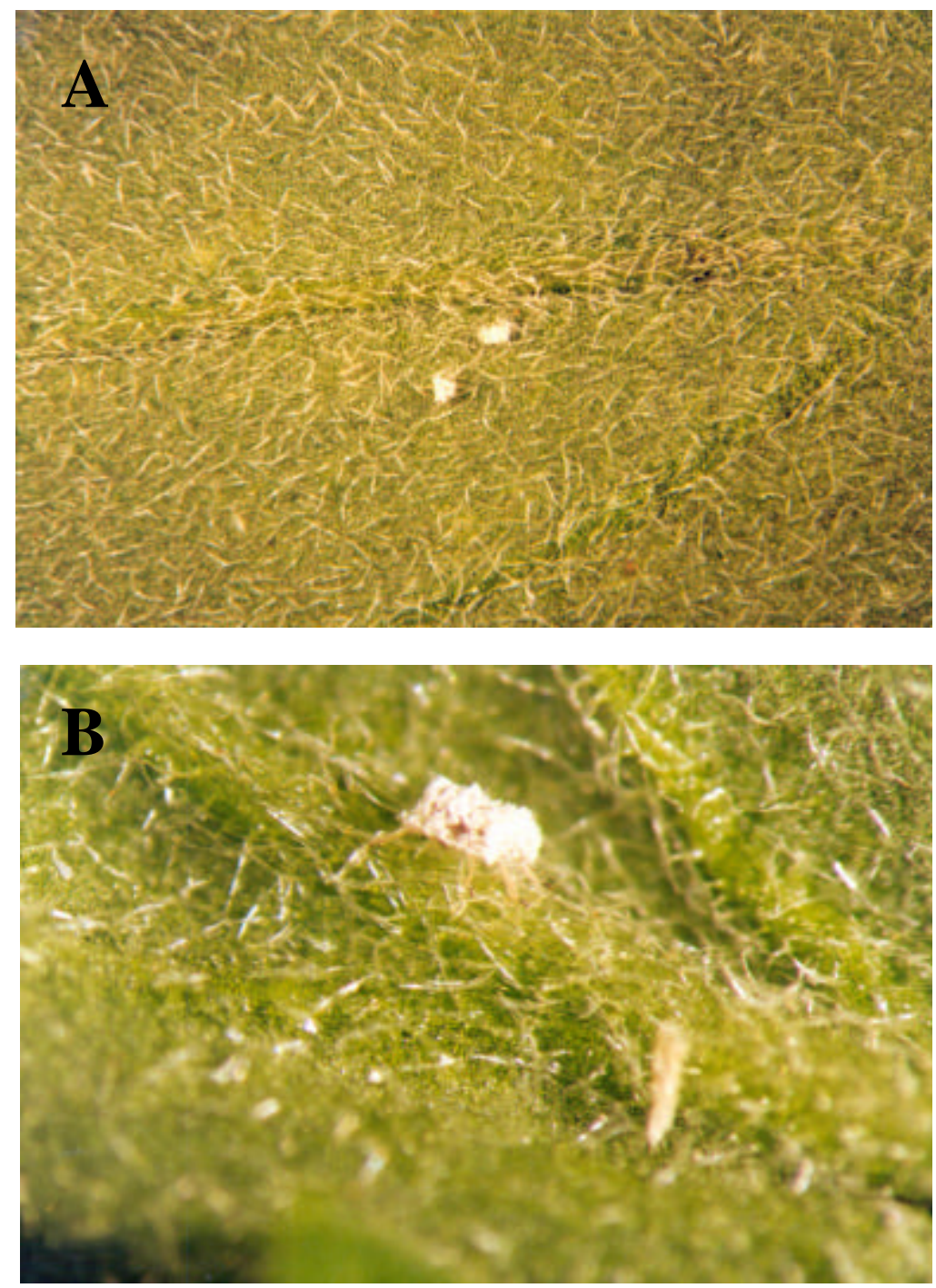

Figura 10 - Tetranychus urticae (A) e pulgão morto (B) nas parcelas tratadas, e com a esporulação do fungo Beauveria bassiana, isolado PL63. 
Atenção especial deve ser conferido às áreas de matrizeiros do crisântemo, por fornecerem os materiais para a propagação vegetativa desta cultura. Caso não seja realizado um controle adequado de $T$. urticae neste local, as estruturas permanecerão infestadas, e posteriormente ao seu enraizamento, serão transplantadas para os canteiros definitivos já contendo este organismo, recomeçando assim um novo ciclo da cultura com ácaros que já se encontram com certo grau de resistência aos produtos utilizados. Deve-se lembrar também, que alguns floricultores, como este em que foi desenvolvido o trabalho, também comercializam estas mudas para terceiros, consequentemente, levando este problema de resistência além da sua propriedade.

\subsubsection{Controle de $T$. urticae na cultura do morango}

Houve interação significativa entre os fatores agente de controle (testemunha, B. bassiana, M. anisopliae e Vertimec $18 \mathrm{CE}$ ), variedade de morango (Sequóia, Dover, Firne, Campinas e Princesa Isabel) e tempo (0, 7, 14 e 21 dias do início do experimento) para a densidade de $T$. urticae por folíolo de morango, ao nível de $1 \%$ de probabilidade (Tabela 12). O efeito do fator bloco não foi significativo, o que indica que a distribuição do ácaro em toda a área experimental foi homogênea. A única interação não significativa foi entre os fatores variedade e tempo.

No que se refere ao efeito do fator tempo na densidade populacional de $T$. urticae, observa-se pela sua linha de tendência obtida com valores da regressão polinomial (Figura 11), que a infestação apresentou, inicialmente, uma tendência de crescimento até aproximadamente o $14^{0}-$ dia, e a partir desse período passou a ocorrer uma redução na população de ácaros. Este fato está possivelmente relacionado a uma mudança na qualidade dos folíolos pela alimentação intensiva e prolongada da praga neste local, estimulando os ácaros à dispersão na busca de locais da planta e mesmo outras plantas em melhores condições para sua alimentação e reprodução (Kennedy \& Smitley, 1985). No último dia de avaliação ( $21^{\underline{0}}$ dia), diversas plantas dos tratamentos 
testemunha e $M$. anisopliae principalmente, apresentavam seus folíolos da porção superior cobertas por teias do ácaro, uma comprovação desta hipótese (Gerson, 1985).

Tabela 12. Quadro da análise de variância para os fatores agente de controle (testemunha, Beauveria bassiana, Metarhizium anisopliae e Vertimec 18 $\mathrm{CE}$ ), variedade de morango (Sequóia, Dover, Firne, Campinas e Princesa Isabel), tempo (0, 7, 14 e 21 dias do início do experimento) e bloco (1, 2 e 3$)$

\begin{tabular}{lccccc}
\hline Causas da Variação & G.L. & S.Q. & Q.M. & Valor de 'F"' & Prob.>F \\
\hline Bloco & 2 & 0,37 & 0,18 & 0,60 & 0,56372 \\
Ag. Controle $^{1}$ & 7 & 57,18 & 8,17 & 26,66 & $0,00001^{* *}$ \\
Resíduo (A) & 14 & 4,29 & 0,31 & & \\
Parcelas & 23 & 61,84 & & & \\
Variedade & 4 & 16,35 & 4,09 & 16,54 & $0,00001^{* *}$ \\
Ag. Controle x Variedade & 28 & 27,72 & 0,99 & 4,01 & $0,00002 * *$ \\
Resíduo (B) & 64 & 15,81 & 0,25 & & \\
Subparcelas & 119 & 121,73 & & & \\
Tempo & 3 & 69,07 & 23,02 & 142,68 & $0,00001^{* *}$ \\
Ag. Controle x Tempo & 21 & 41,62 & 1,98 & 12,28 & $0,00001^{* *}$ \\
Variedade x Tempo & 12 & 2,32 & 0,19 & 1,20 & 0,28532 \\
Ag. Controle x Var. ${ }^{2}$ x Temp. ${ }^{3}$ & 84 & 20,21 & 0,24 & 1,49 & $0,01020^{* *}$ \\
Resíduo (C) & 240 & 38,73 & 0,16 & & \\
Total & 479 & 293,69 & & & \\
\hline Ag. Conte & & & & & \\
\hline
\end{tabular}

${ }_{1}$ Ag. Controle $=$ agente de controle

2 Var. = variedade

${ }^{3}$ Temp. $=$ tempo. 


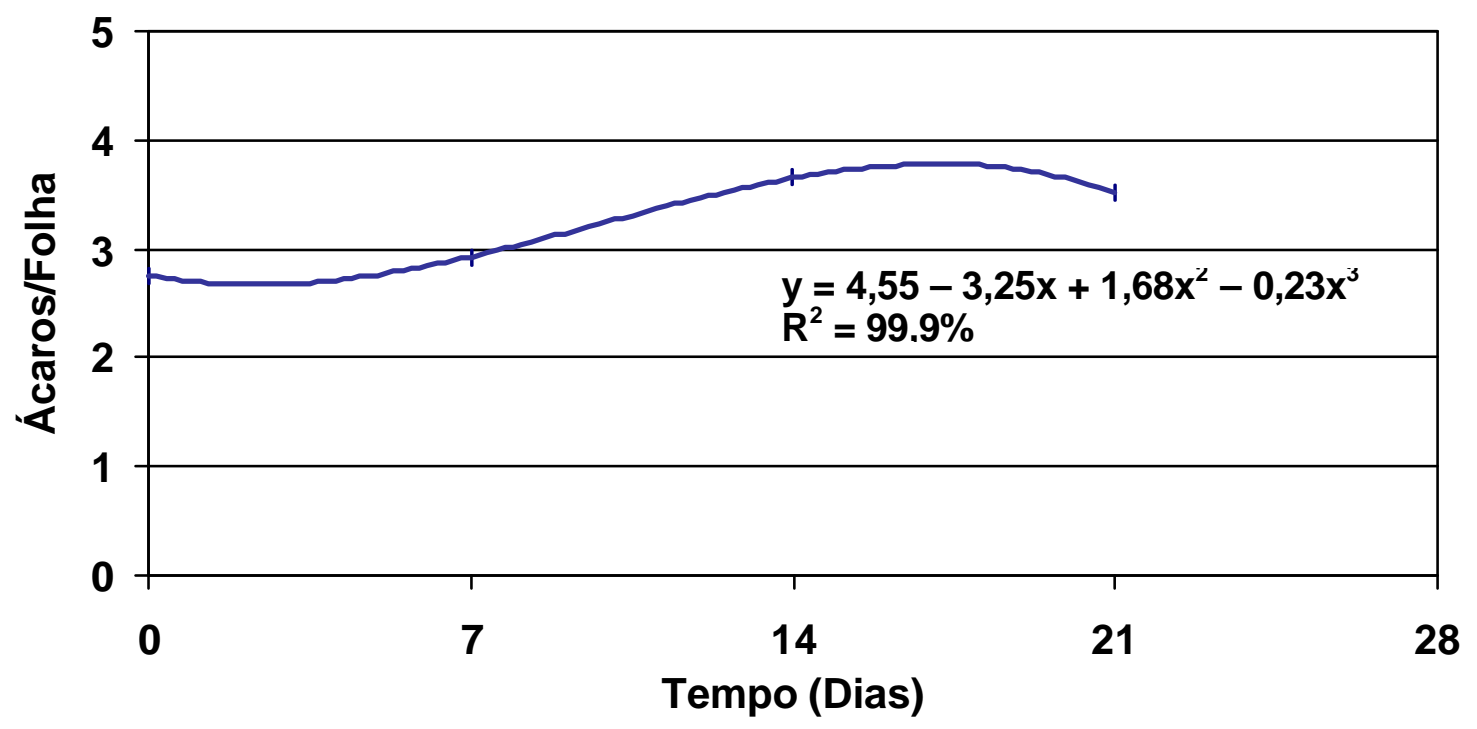

Figura 11 - Densidade populacional de Tetranychus urticae por folíolo de morango em função dos momentos de avaliação $(0,7,14$ e 21 dias do início do experimento).

A análise dos níveis para o fator agente de controle demonstrou diferenças significativas entre estes quanto a densidade média do ácaro ao longo de todo o período de estudo (Tabela 13). Os níveis estão distribuídos em quatro grupos distintos entre si. O primeiro grupo, representado por M. anisopliae e testemunha com densidades médias de 56,91 e 43,39 ácaros/folíolo, respectivamente, foram os que apresentaram as maiores infestações da praga ao longo de todo os 21 dias de avaliação. No segundo grupo fazem parte as duas menores concentrações do isolado PL63 de B. bassiana $\left(5 \times 10^{6}\right.$ e $1 \times 10^{7}$ conídios/mL), com densidades médias de 30,49 e 29,57 ácaros/folíolo, respectivamente. Nos demais grupos encontram-se os melhores tratamentos. Entre os entomopatógenos figuram-se as maiores concentrações do isolado PL63 $\left(5 \times 10^{7}\right.$ e $1 \times 10^{8}$ conídios $\left./ \mathrm{mL}\right)$ e o

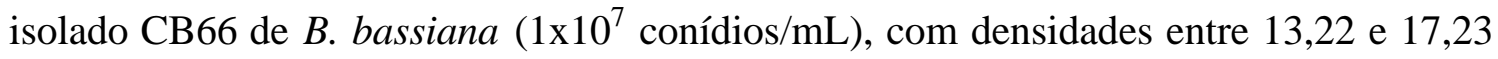
ácaros/folíolo. Estes porém, foram inferiores ao Vertimec $18 \mathrm{CE}$, com infestação média de 4,31 ácaros/folíolo durante o período. 
Tabela 13. Efeito de Beauveria bassiana, Metarhizium anisopliae e Vertimerc $18 \mathrm{CE}$ sobre Tetranychus urticae em folíolos de morango ao longo dos 21 dias

\begin{tabular}{|c|c|}
\hline Tratamento & Número médio de ácaros/folíolo \\
\hline M. anisopliae $(1037)-1 \times 10^{7} \mathrm{con} . / \mathrm{mL}$ & $56,91 \mathrm{a}$ \\
\hline Testemunha & $43,39 \mathrm{a}$ \\
\hline B. bassiana (PL63) - 5 $\times 10^{6}$ con. $/ \mathrm{mL}$ & $30,49 \quad b$ \\
\hline B. bassiana (PL63) - $1 \times 10^{7}$ con. $/ \mathrm{mL}$ & $29,57 \mathrm{~b}$ \\
\hline B. bassiana $(\mathrm{CB} 66)-1 \times 10^{7}$ con. $/ \mathrm{mL}$ & $17,23 \quad \mathrm{c}$ \\
\hline B. bassiana (PL63) $-1 \times 10^{8}$ con. $/ \mathrm{mL}$ & 13,34 \\
\hline 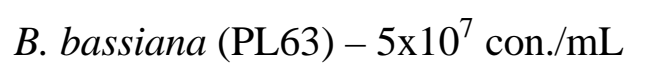 & 13,22 \\
\hline Vertimec 18 CE (abamectin) & 4,31 \\
\hline
\end{tabular}

*Médias seguidas por letras distintas diferem entre si pelo Teste de Tukey $(\mathrm{P} \leq 0,05)$.

O isolado PL63 apresentou efeito de controle sobre T. urticae desde as concentrações mais baixas, aumentando gradativamente o nível de controle a medida que a suspensão de conídios na calda inseticida se tornava mais concentrada. Este comportamento é semelhante ao que ocorre com inseticidas químicos. O maior potencial de inóculo aumenta a chance de sucesso no desenvolvimento de doença na praga, pois agem contra este o efeito do ambiente sobre a viabilidade de seus conídios, bem como, as barreiras físicas e celulares da praga à sua infecção (Alves \& Lecuona, 1998; Omoto \& Alves, 1998). Nas duas maiores concentrações deste isolado, a densidade média ao longo do ensaio foi de aproximadamente 13 ácaros/folíolo, valor este 3 vezes maior do que os observados para o Vertimec $18 \mathrm{CE}$, mas 3 vezes menor do que na testemunha. Entretanto, os níveis populacionais da praga nestas duas concentrações do PL63 podem ser considerados elevados, com possíveis reflexos na produção dos cultivares de morango caso a infestação tivesse ocorrido durante o período de produção da cultura, pois eram nítidos os danos aos tecidos foliares das cultivares tanto em sua face superior com inferior. O rendimento da cultura não foi avaliado pois o ensaio foi conduzido após a colheita dos frutos da última florada das cultivares. O isolado 1037 de M. anisopliae na concentração de $1 \times 10^{7}$ conídios/mL não apresentou qualquer efeito de controle sobre $T$. urticae, embora esta espécie de fungo seja patogênica à T. urticae (Tamai, 1998). 
Quando comparado com os isolados PL63 e CB66 na mesma concentração, seu desempenho foi inferior estatisticamente. O isolado CB66 mostrou-se, nas condições do ensaio, ser um material promissor para o controle de T. urticae, com níveis de controle semelhantes ao isolado PL63.

O estudo do efeito das variedades de morango sobre a população de T. urticae revelou que todas as variedades foram suscetíveis ao ácaro, apresentando porém níveis variáveis de infestação (Tabela 14). As variedades Campinas e Princesa Isabel foram as que apresentaram as menores densidades do ácaro ao longo de todo o período de avaliação (21 dias), com 18,90 e 12,11 ácaros/folíolo em média, respectivamente. Estes valores são de 2 a 3 vezes menores do que o observado para a variedade Firne (36,61 ácaros/folíolo), a mais infestada.

Tabela 14. Efeito da variedade de morango sobre a população de Tetranychus urticae

\begin{tabular}{lc}
\hline Variedade & Número médio de ácaros/folíolo \\
\hline Firne & $36,61 \mathrm{a}$ \\
Dover & $32,55 \mathrm{a} \mathrm{b}$ \\
Sequóia & $30,12 \quad \mathrm{~b}$ \\
Campinas & $18,90 \quad \mathrm{c}$ \\
Princesa Isabel & $12,11 \quad \mathrm{~d}$ \\
\hline
\end{tabular}

*Médias seguidas por letras distintas diferem entre si pelo teste de Tukey $(\mathrm{P} \leq 0,05)$.

Analisando-se o desenvolvimento das populações de $T$. urticae nas variedades de morango para o tratamento testemunha, comprovou-se a tendência que as variedades Princesa Isabel e Dover possuem de ser a menos e a mais infestada pela praga, respectivamente. Porém, a variedade Princesa Isabel não se diferenciou estatisticamente das variedades Sequóia e Campinas em qualquer uma das avaliações conduzidas, apesar de ter havido grandes diferenças entre estas três variedades, como os observados aos 14 dia (Tabela 15). 
Tabela 15. Número médio de Tetranychus urticae por folíolo no tratamento testemunha das diferentes variedades de morango e momentos de avaliação

\begin{tabular}{|c|c|c|c|c|c|c|c|c|c|c|c|}
\hline \multirow{2}{*}{$\begin{array}{l}\text { Variedades } \\
\text { Dover }\end{array}$} & \multicolumn{2}{|c|}{0 Dia } & \multicolumn{3}{|c|}{7 Dias } & \multicolumn{3}{|c|}{14 Dias } & \multicolumn{3}{|c|}{21 Dias } \\
\hline & $11,00 \mathrm{a}$ & $\mathrm{C}$ & 49,30 & $\mathrm{a}$ & B & $130,00 \mathrm{a}$ & & A & 98,77 & $\mathrm{a}$ & A B \\
\hline Firne & $7,47 \mathrm{a}$ & B & 20,10 & $a b$ & B & 96,53 a & & A & 109,13 & $\mathrm{a}$ & $\mathrm{A}$ \\
\hline Sequóia & $7,90 \mathrm{a}$ & $\mathrm{C}$ & 12,53 & $\mathrm{~b}$ & B C & 34,23 & U & B & 90,67 & $\mathrm{a}$ & A \\
\hline Campinas & $1,90 \mathrm{a}$ & B & 10,00 & $\mathrm{~b}$ & B & 55,43 a & 0 & & 54,43 & $\mathrm{a}$ & $\mathrm{A}$ \\
\hline Princesa Isabel & $1,70 \mathrm{a}$ & B & 8,90 & $\mathrm{~b}$ & B & 18,23 & & A B & 49,57 & $\mathrm{a}$ & A \\
\hline
\end{tabular}

* Médias seguidas por letras distintas diferem entre si pelo Teste de Tukey $(\mathrm{P} \leq 0,05)$. Letras maiúsculas para comparação entre médias na linha, e minúsculas para comparações na coluna.

Ao se analisar o desenvolvimento populacional do ácaro para o isolado PL63 nas concentrações de $5 \times 10^{7}$ e $1 \times 10^{8}$ conídios/mL (Tabelas 16 e 17), dois dos tratamentos que apresentaram melhores níveis de controle da praga, não houve evidências de que as variedades interferiram na eficiência de controle da praga pelo entomopatógeno. Neste caso, as variedades Firne e Princesa Isabel em nenhum momento se diferiram estatisticamente. Contudo, a utilização de variedades como a Campinas e Princesa Isabel representam uma boa opção de manejo de T. urticae com químico ou biológico (ácaro predador e entomopatógeno). Ao permitir uma menor taxa de crescimento populacional auxilia o controle, pois vão permitir um maior período sem a necessidade de novas pulverizações e/ou liberações destes agentes de controle ao longo de seu ciclo de produção.

Todas são variedades comerciais, o que é uma grande vantagem, pois não se trata de materiais silvestres que precisariam passar por melhoramento genético para a incorporação de outras característica agronômicas desejadas. A opção pela cultivar deve ser precedido por uma boa análise, não somente quanto ao seu comportamento com relação às pragas, mas também é necessário que a variedade atenda as necessidades da localidade de cultivo (clima, solo, suscetibilidade à doenças, etc.) e do mercado a qual se destina sua produção. 
Tabela 16. Número médio de Tetranychus urticae por folíolo no tratamento Beauveria bassiana, isolado PL63 $\left(5 \times 10^{7}\right.$ conídios/mL), das diferentes variedades de morango e momentos de avaliação

\begin{tabular}{|c|c|c|c|c|c|c|c|c|c|}
\hline \multirow{2}{*}{$\frac{\text { Variedades }}{\text { Campinas }}$} & \multicolumn{2}{|c|}{0 Dia } & \multicolumn{2}{|c|}{7 Dias } & \multicolumn{3}{|c|}{14 Dias } & \multicolumn{2}{|c|}{21 Dias } \\
\hline & $2,43 \mathrm{a}$ & B & $16,10 \mathrm{a}$ & B & 57,43 & $a b$ & A & $17,10 \mathrm{a}$ & A B \\
\hline Sequóia & $3,23 \mathrm{a}$ & B & $11,53 \mathrm{a}$ & B & 66,90 & $\mathrm{a}$ & A & $16,67 \mathrm{a}$ & B \\
\hline Princesa Isabel & 3,67 a & A & $4,43 \mathrm{a}$ & A & 12,53 & c & A & $5,00 \mathrm{a}$ & A \\
\hline Dover & $1,57 \mathrm{a}$ & A & 4,13 a & A & 14,23 & b c & A & $7,13 \mathrm{a}$ & A \\
\hline Firne & $4,10 \mathrm{a}$ & A & $0,67 \mathrm{a}$ & $\mathrm{A}$ & 5,10 & c & A & $10,43 \mathrm{a}$ & $\mathrm{A}$ \\
\hline
\end{tabular}

* Médias seguidas por letras distintas diferem entre si pelo Teste de Tukey $(\mathrm{P} \leq 0,05)$. Letras maiúsculas para comparação entre médias na linha, e minúsculas para comparações na coluna.

Tabela 17. Número médio de Tetranychus urticae por folíolo no tratamento Beauveria

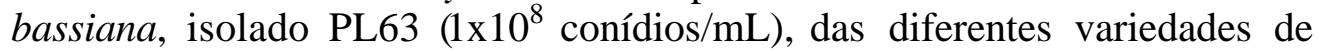
morango e momentos de avaliação

\begin{tabular}{|c|c|c|c|c|c|c|c|c|}
\hline \multirow{2}{*}{$\begin{array}{l}\text { Variedades } \\
\text { Campinas }\end{array}$} & \multicolumn{2}{|c|}{0 Dia } & \multicolumn{2}{|c|}{7 Dias } & \multicolumn{2}{|c|}{14 Dias } & \multicolumn{2}{|c|}{21 Dias } \\
\hline & 8,90 a & B & $11,67 \mathrm{a}$ & B & $66,20 \mathrm{a}$ & A & 14,43 a & B \\
\hline Sequóia & $4,67 \mathrm{a}$ & B & $5,30 \mathrm{a}$ & B & $39,87 \mathrm{a} \mathrm{b}$ & A & $12,33 \mathrm{a}$ & A B \\
\hline Princesa Isabel & $3,10 \mathrm{a}$ & A & 3,23 a & A & 15,90 & b c A & $13,10 \mathrm{a}$ & A \\
\hline Dover & 6,43 a & A & $2,43 \mathrm{a}$ & A & 4,13 & c A & $10,10 \mathrm{a}$ & A \\
\hline Firne & 5,33 a & B & $1,87 \mathrm{a}$ & B & 8,80 & b c A B & 29,10 a & A \\
\hline
\end{tabular}

* Médias seguidas por letras distintas diferem entre si pelo Teste de Tukey $(\mathrm{P} \leq 0,05)$. Letras maiúsculas para comparação entre médias na linha, e letras minúsculas para comparações na coluna.

O fato das cinco variedades de morango não apresentarem empecilhos para o contato da praga com o entomopatógeno explica os índices semelhantes de controle observados para as diferentes variedades quando tratadas com o entomopatógeno. Um bom exemplo em que as características morfológicas interferem no nível de controle da praga pelo seu inimigo natural é o controle das moscas brancas B. tabaci e Trialeurodes vaporariorum (Sternorrhyncha: Aleyrodidae) pelo parasitóide Encarsia formosa (Hymenoptera: Aphelinidae) em estufas na Europa. Foram conduzidas pesquisas que 
resultaram em variedades de plantas hospedeiras destas pragas apresentando reduzida pubescência em suas folhas, facilitando desta forma a localização das ninfas destes insetos pelo inimigo natural (Van Lenteren, 1995).

Neste experimento houve uma maior dificuldade de se controlar o ácaro pelo uso de B. bassiana quando comparado com o desenvolvido em matrizeiros de crisântemo. Embora os equipamentos de pulverização sejam diferentes nos dois experimentos, atomizador costal motorizado Jacto (crisântemo) e pulverizador costal manual Jacto adaptado com pressão proporcionada por $\mathrm{CO}_{2}$ (morango), estes aparentemente tiveram pouco efeito sobre o controle da praga, pois cumpriram adequadamente o propósito de molhar convenientemente a face inferior das folhas das plantas, no local referido como sendo o de maior concentração do ácaro na planta. Contudo, seria importante comprovar esta hipótese, determinando-se alguns informações sobre escorrimento e quantidade de conídios que permaneceram sobre as folhas após a pulverização pelos equipamentos. Quanto a concentração dos entomopatógenos, para o morango foram utilizadas concentrações inferiores $\left(5 \times 10^{6}\right.$ a $1 \times 10^{8}$ conídios $\left./ \mathrm{mL}\right)$ em relação ao crisântemo $\left(2 \times 10^{8}\right.$ conídios $\left./ \mathrm{mL}\right)$, em vista a avaliação de concentrações que fossem mais econômicas ao produtor. Como referido, a quantidade de inóculo afeta a eficiência de sucesso no desenvolvimento da doenças, consequentemente com reflexos nas atividades alimentar e reprodutiva do hospedeiro infectado.

Outro fator envolvido refere-se a elevada população inicial da praga que foi de 6,7 ácaros/folíolo no morango contra 2,6 ácaros/folha no crisântemo. Considerando-se que esta espécie de ácaro apresenta uma rápida taxa de crescimento populacional, já era esperado que nas avaliações seguintes os níveis populacionais nas parcelas de morango fossem elevadas e também maiores do que os observados no crisântemo. Este fato é de fundamental importância em se tratando de controle de T. urticae com B. bassiana, pois este organismo necessita de 3 a 5 dias para causar a morte da praga (Tamai, 1998; Tamai et al., 1999), comparado com o efeito quase imediato de muitos produtos químicos. Nos primeiros dias deste período, especialmente, os ácaros mesmo inoculados com o entomopatógeno podem manter suas atividades de alimentação e postura em taxas próximas das normais, garantindo assim uma nova geração da praga na cultura. Este 
fenômeno foi observado para diversos isolados de $B$. bassiana infectando fêmeas recém emergidas deste ácaro (Tamai \& Alves, dados não publicados). Posteriormente, estudos conduzidos por Neves et al. (1997) sobre a infecção de T. urticae por B. bassiana suportam esta informação, pois até as 48 horas após a inoculação predominam as fases de germinação de conídios e penetração do fungo pela cutícula do ácaro. Esta fase precede a colonização do corpo do hospedeiro que se caracteriza, de modo geral, por ocasionar distúrbios na fisiologia normal de seus hospedeiros, como redução na taxa de oviposição (Alves, 1998a; Alves \& Pereira, 1998). O próprio manejo de T. urticae feito em estufas na Europa com a utilização do ácaro predador Phytoseiulus persimilis (Acari: Phytoseiidae) apresenta dificuldades quando a densidade populacional da praga é elevada. Neste caso, são feitas pulverizações de acaricidas seletivos ao predador, como o Torque (Óxido de fenbutatina), para restaurar o equilíbrio entre presa/predador. Como resultado, o controle biológico é algumas vezes integrado com o controle químico. Recentemente, problemas de resistência da praga ao óxido de fenbutatina tem ameaçado sua utilização no sistema de controle (Jacobson et al., 1999; Shipp et al., 2000).

As diferenças entre os sistemas de produção das culturas do morango e crisântemo podem também explicar em parte a diferença na eficiência de controle da praga para as duas culturas. Para o morango, a irrigação era feita durante o dia diretamente sobre o substrato e não sobre a planta, o que provavelmente proporcionou condições ambientais menos favoráveis a infeção da praga pelo entomopatógeno, como referido anteriormente.

\subsection{Conclusões}

- B. bassiana pode ser utilizada com eficiência no controle de T. urticae em matrizeiros de crisântemo

- condições de umidade relativa elevada e uso de equipamento apropriado de pulverização são imprescindíveis para o controle de T. urticae com B. bassiana 
- o crescimento populacional de T. urticae é influenciado pela variedade de morango, contudo, esta não afeta a eficiência de B. bassiana no controle da praga

- densidades populacionais elevadas de T. urticae são desfavoráveis para o uso de $B$. bassiana no controle desse ácaro em morango

- B. bassiana pode ser utilizada com sucesso em programas de controle integrado de pragas em ambiente de cultivo protegido (estufas). 


\section{CONCLUSÕES GERAIS}

- os isolados CB 2, CB 146, CB 157, CB 161 e CB 166 de B. bassiana e os isolados CB 345, CB 348, 1247, 1286 e PL47 de M. anisopliae são altamente patogênicos e promissores para o controle microbiano de T. urticae. Todos os isolados desses fungos produzem cristais de cálcio no interior do corpo dos ácaros infectados

- conídio aéreo, célula de levedura e blastósporo de cinco isolados de B. bassiana são patogênicos ao ácaro $T$. urticae. Diferenças significativas $(\mathrm{P} \geq 0,05)$ para $\mathrm{CL}_{50} \mathrm{e}$ coeficiente angular ocorrem entre os isolados e entre as estruturas infectivas de $B$. bassiana

- uma porcentagem menor de produtos fungicidas são compatíveis com B. bassiana, quando comparados com os inseticidas e/ou acaricidas. Além do ingrediente ativo, outros fatores estão relacionados com a toxicidade de um produto fitossanitários para $B$. bassiana

- B. bassiana pode ser utilizada com eficiência no controle de T. urticae em matrizeiros de crisântemo. Condições de umidade relativa elevada e uso de equipamento apropriado de pulverização são imprescindíveis para o controle do ácaro com B. bassiana. Densidades populacionais elevadas de T. urticae são desfavoráveis para o uso deste fungo no controle do ácaro em morango

- B. bassiana pode ser utilizada com sucesso em programas de controle integrado de pragas em ambiente de cultivo protegido (estufas). 


\section{REFERÊNCIAS BIBLIOGRÁFICAS}

ABBOTT, W.S. A method of computing the effectiveness of an insecticide. Journal of Economic Entomology, v.18, p.265-267, 1925.

ACEVEDO, J.L.R.; ROSAS, L.S. Control biológico de Brevipalpus spp. en Citrus aurantifolia en Guerrero, México. Manejo Integrado de Plagas, n.55, p.56-59, 2000.

ALMEIDA, J.E.M.; ALVES, S.B. Mortalidade de Heterotermes tenuis (Hagen) atraídos por armadilhas com Beauveria bassiana (Bals.) Vuill. e Imidacloprid. Anais da Sociedade Entomologica do Brasil, v.25, n.3, p.507-512, 1996.

ALMEIDA, J.E.M.; BATISTA FILHO, A. Banco de microrganismos entomopatogênicos. Biotecnologia Ciência \& Desenvolvimento, n.20, p.30-33, 2001.

ALMEIDA, J.E.M.; ALVES; S.B.; PEREIRA, R.M. Selection of Beauveria spp. isolates for control of the termite Heterotermes tenuis (Hagen,1858). Journal of Applied Entomology, v.121, p.539-543, 1997.

ALVES, S.B. Controle microbiano de insetos. São Paulo: Manole, 1986a. cap.4, p.2864: Epizootiologia.

ALVES, S.B. Controle microbiano de insetos. São Paulo: Manole, 1986b. cap.6, p.73126: Fungos entomopatogênicos. 
ALVES, S.B. Controle microbiano de insetos. 2.ed. Piracicaba: FEALQ, 1998a. cap.11, p.289-381: Fungos entomopatogênicos.

ALVES, S.B. Controle microbiano de insetos. 2.ed. Piracicaba: FEALQ, 1998b. cap.1, p.21-37: Patologia e controle microbiano: vantagens e desvantagens.

ALVES, S.B.; LECUONA, R.E. Epizootiologia aplicada ao controle microbiano de insetos. In: ALVES, S.B. (Ed.). Controle microbiano de insetos. 2.ed. Piracicaba: FEALQ, 1998. cap.5, p.97-169.

ALVES, S.B.; PEREIRA, R.M. Distúrbios fisiológicos provocados por entomopatógenos. In: ALVES, S.B. (Ed.). Controle microbiano de insetos. 2.ed. Piracicaba: FEALQ, 1998. cap.2, p.39-54.

ALVES, S.B.; PEREIRA, R.M. Produção massal de Metarhizium anisopliae (Metsch.) Sorok. e Beauveria bassiana (Bals.) Vuill. em bandejas. Ecossistema, v.14, p.188-192, 1989.

ALVES, S.B.; MOINO JÚNIOR, A.; ALMEIDA, J.E.M. Desenvolvimento, potencial de uso e comercialização de produtos microbianos. In: ALVES, S.B. (Ed.). Controle microbiano de insetos. 2.ed. Piracicaba: FEALQ, 1998a. cap.40, p.1143- 1163.

ALVES, S.B.; MOINO JÚNIOR, A.; ALMEIDA, J.E.M. Produtos fitossanitários e entomopatógenos. In ALVES, S.B. (Ed.). Controle microbiano de insetos. 2.ed. Piracicaba: FEALQ, 1998b. cap. 08, p.217-238.

ALVES, S.B.; ALMEIDA, J.E.M.; MOINO JÚNIOR, A.; ALVES, L.F.A. Técnicas de laboratório. In ALVES, S.B. (Ed.). Controle microbiano de insetos. 2.ed. Piracicaba: FEALQ, 1998c. cap. 20, p.637-711. 
ALVES, S.B.; VIEIRA, S.A.; MACEDO, D.; LOPES, R.B. Diversidade genética de isolados de Metarhizium anisopliae detectada por RAPD-PCR e patogenicidade a Diatraea saccharalis. In: SIMPÓSIO DE CONTROLE BIOLÓGICO, 7., Poços de Caldas, 2001a. Resumos. Lavras: UFLA, 2001a. p.175.

ALVES, S.B.; LOPES, R.B.; TAMAI, M.A.; MOINO JÚNIOR, A.; ALVES, L.F.A. Compatibilidade de produtos fitossanitários com entomopatógenos em citros. Laranja, v.21, n.2, p.295-306, 2000.

ALVES, S.B.; SILVEIRA, C.A.; LOPES, R.B.; TAMAI, M.A.; RAMOS, E.Q; SALVO, S. Eficácia de Beauveria bassiana, imidacloprid e thiacloprid no controle de Bemisia tabaci e na incidência do BGMV. Manejo Integrado de Plagas, n.61, p.32-37, $2001 b$.

AMARAL, E.; ALVES, S.B. Insetos úteis. Piracicaba: Livroceres, 1979. 88p.

ANDERSON, T.E.; ROBERTS, D.W. Compatibility of Beauveria bassiana isolates with insecticide formulations used in Colorado potato beetle (Coleoptera: Chrysomelidae) control. Journal of Economic Entomology, v.76, p.1437-1441, 1983.

ANDREI, E. Compêndio de defensivos agrícolas. 6 ed. São Paulo: Organização Andrei, 1999. p.672.

BARTKOWSKI, J.; ODINDO, O.; OTIENO, W.A. Some fungal pathogens of the cassava green spider mites Mononychellus spp. (Tetranychidae) in Kenya. Insect Science and its Application, v.9, n.4, p.457-459, 1988. 
BATISTA FILHO, A.; ALVES, S.B.; ALVES, L.F.A.; PEREIRA, R.M.; AUGUSTO, N.T. Formulação de entomopatógenos. In: ALVES, S.B. (Ed.). Controle microbiano de insetos. 2.ed. Piracicaba: FEALQ, 1998. cap.31, p.917-965.

BEAVERS, J.B.; REED, D.K. Susceptibility of seven tetranychids to the nonoccluded virus of the citrus red mite and the correlation of the carmine spider mite as a vector. Journal of Invertebrate Pathology, v.20, p.279-283, 1972.

BEDENDO, I.P. Ambiente e doença. In: BERGAMIN FILHO, A.; KIMATI, H.; AMORIM, L. (Ed.). Manual de fitopatologia: princípios e conceitos. São Paulo: Agronômica Ceres, 1995. v.1, cap.18. p.331-341.

BELLO, V.A.; PACCOLA-MEIRELLES, L.D. Localization of auxotrophic and benomyl resistance markers through the parasexual cycle in the Beauveria bassiana (Bals.) Vuill entomopathogen. Journal of Invertebrate Pathology, v.72, p.119-125, 1998.

BIDOCHKA, M.J.; St. LEGER, R.J.; JOSHI, L.; ROBERTS, D.W. The rodlet layer from aerial and submerged conidia of the entomopathogenic fungus Beauveria bassiana contains hydrophobin. Mycological Research, v.99, n.4, p.403-406, 1995.

BIRD, F.T. A virus disease of the European red mite, Panonychus ulmi (Koch). Canadian Journal of Microbiology, v.13, p.1131, 1967.

BJORNSON, S.; RAWORTH, D.A.; BÉDARD, C. Abdominal discoloration and the predatory mite Phytoseiulus persimilis Athias-Henriot: prevalence of symptoms and their correlation with short-term performance. Biological Control, v.19, p.17-27, 2000. 
BOUCIAS, D.G.; PENDLAND, J.C. Principles of insect pathology. Norwell: Kluwer Academic, 1998. cap.10, p.321-364: Entomopathogenic fungi: fungi imperfecti.

BOUCIAS, D.G.; McCOY, C.W.; JOSLYN, D.J. Isozyme differentiation among 17 geographical isolates of Hirsutella thompsonii. Journal of Invertebrate Pathology, v.39, p.329-337, 1982.

BOUCIAS, D.G.; PENDLAND, J.C.; LATGE, J.P. Nonspecific factors involved in attachment of entomopathogenic deuteromycetes to host insect cuticle. Applied Environmental Microbiology, v54, p.1795-1805, 1988.

BURGES, H.D. Teratogenicity of the thermostable beta-exotoxins of Bacillus thuringiensis in Galleria mellonella. Journal of Invertebrate Pathology, v.26, p.419-420, 1975.

CABRERA, R.I.; CACERES, I.; DOMINGUEZ, D. Estudio de dos especies de Hirsutella y sus hospedantes en el cultivo de la guayaba Psidium guajava. Agrotecnia de Cuba, v.19, n.1, p. 29-34, 1987.

CARNER, G.R. A description of the life cycle of Entomophthora sp. in the two-spotted spider mite. Journal of Invertebrate Pathology, v.28, p.245-254, 1976.

CARNER, G.R.; CANERDAY, T.D. Field and laboratory investigations with Entomophthora fresenii, a pathogen of Tetranychus spp. Journal of Economic Entomology, v.61, n.4, p.956-959, 1968.

CARNER, G.R.; CANERDAY, T.D. Entomophthora sp. as a factor in the regulation of the two-spotted spider mite on cotton. Journal of Economic Entomology, v.63, n.2, p.638-640, 1970. 
CHAPMAN, M.H.; HOY, M.A. Relative toxicity of Bacillus thuringiensis var. tenebrionis to the two-spotted spider mite (Tetranychus urticae Koch) and its predator Metaseiulus occidentalis (Wesbitt) (Acari, Tetranychidae and Phytoseiidae). Journal of Applied Entomology, v.111, n.2, p.147-154, 1991.

CORREIA, A.C.B.; GRAVENA, S.; KREBKSY, E.O. Primeira citação do fungo Hirsutella thompsonii var. thompsonii parasitando Phyllocoptruta oleivora (Ashm.) (Acari, Eriophyidae) no Brasil. Laranja, v.13, n.2, p. 553-558, 1992.

CRANHAM, J.E.; HELLE, W. Pesticide resistance in tetranychidae. In: HELLE, W.; SABELIS, M.W. (Ed.). Spider mites. their biology, natural enemies and control. Amsterdam: Elsevier, 1985. v.1B, cap.3.4, p.405-421.

DELALIBERA JÚNIOR, I.; MORAES, G.J.; SMITH, L. Patogenicidade de isolados de Neozygites cf. floridana aos ácaros Mononychellus tanajoa e Tetranychus urticae. In: CONGRESSO BRASILEIRO DE ENTOMOLOGIA, 16., ENCONTRO NACIONAL DE FITOSSANITARISTAS, 7., Salvador, 1997. Anais. Salvador: SEB, 1997. p.151.

DELALIBERA JÚNIOR, I.; SOSA GOMEZ; D.; MORAES, G.J. Infection of Mononychelllus tanajoa (Acari: Tetranychidae) by the fungus Neozygites sp. (Entomophthorales) in northeastern Brazil. Florida Entomologist, v.75, n.1, p.145147, 1992.

DRESNER, E. Culture and use of entomogenous fungi for the control of insect pests. Contributions from Boyce Thompson Institute, v.15, p.319-335, 1949.

ELLIOT, S.L. Ecology and epizootiology of Neozygites floridana, a pathogen of the cassava green mite. Silwood Park, 1998. 177p. PhD (Dissertation) - Imperial College. 
FARIA, M.R.; MAGALHÃES, B.P. O uso de fungos entomopatogênicos no Brasil. Situação atual e perspectivas. Biotecnologia Ciência \& Desenvolvimento, n.22, p.18-21, 2001.

FISHER, F.E. An Entomophthora attacking citrus red mite. Florida Entomologist, v.34, n.3, p.83-88, 1951.

FLECHTMANN, C.H.W. Ácaros de importância agrícola. 6.ed. São Paulo: Nobel, 1985. 189p.

FNP CONSULTORIA \& COMERCIO. Agrianual 2001: anuário da agricultura brasileira. São Paulo, 2001. 545p.

FRANZ, J.M.; BOGENSCHÜTZ, H.; HASSAN, S.A.; HUANG, P.; NATON, E.; SUTER, H.; VIGGIANI, G. Results of a joint pesticide test programme by the Working Group: Pesticides and Beneficial Arthropods. Entomophaga, v.25, n.3, p.231-236, 1980.

FRIGO, S.M.; AZEVEDO, J.L. Variabilidade natural para crescimento, conidiação e sobrevivência à luz ultra-violeta em Metarhizium anisopliae (Metsch.) Sorokin. Revista de Agricultura, Piracicaba, v.61, n.2, p.137-147, 1986.

FURLANETO, M.C.; PAIAO, F.G.; PINTO, F.G.S.; FUNGARO, M.H.P. Transformation of the entomopathogenic fungus Metarhizium flavoviride to high resistance to benomyl. Canadian Journal of Microbiology, v.45, n.10, p.875-878, 1999. 
GALLO, D.; NAKANO, O.; SILVEIRA NETO, S.; CARVALHO, R.P.L.; BATISTA, G.C.; BERTI FILHO, E.; PARRA, J.R.P.; ZUCCHI, R.A.; ALVES, S.B.; VENDRAMIM, J.D. Manual de entomologia agrícola. 2.ed. São Paulo: Ceres, 1988. 649p.

GARDNER, W.A.; OETTING, R.D.; STOREY, G.K. Susceptibility of the two-spotted spider mite, Tetranychus urticae Koch, to the fungal pathogen Hirsutella thompsonii Fisher. Florida Entomologist, v.65, n.4, p. 458-465, 1982.

GERSON, U. Webbing. In: HELLE, W.; SABELIS, M.W. (Ed.). Spider mites. their biology, natural enemies and control. Amsterdam: Elsevier, 1985. v.1A, cap.1.4.1. p.223-232.

GERSON, U.; KENNETH, R.; MUTTATH, T.I. Hirsutella thompsonii, a fungal pathogen of mites. II. Host-pathogen interactions. Annals of Applied Biology, v.91, n.1, p.29-40, 1979.

GHINI, R.; KIMATI, H. Resistência de fungos a fungicidas. Jaguariúna: Embrapa Meio Ambiente, 2000. 78p.

GILMORE, J.E. Preliminary field evaluation of a noninclusion virus for control of the citrus red mite. Journal of Economic Entomology, v.58, n.6, p.1136-1140, 1965.

GILMORE, J.E.; TASHIRO, H. Fecundity, longevity, and transinfectivity of citrus red mites (Panonychus citri) infected with a noninclusion virus. Journal of Invertebrate Pathology, v.8, p.334-339, 1966.

HABIB, M.E.M.; ANDRADE, C.F.S. Bactérias entomopatogênicas. In: ALVES, S.B. (Ed.). Controle microbiano de insetos. São Paulo: Manole, 1986. cap.7, p.127170. 
HABIB, M.E.M.; ANDRADE, C.F.S. Bactérias entomopatogênicas. In: ALVES, S.B. (Ed.). 2.ed. Controle microbiano de insetos. Piracicaba: FEALQ, 1998. cap.12, p.383-446.

HAJEK, A.E.; St. LEGER, R.J. Interaction between fungal pathogens and insect hosts. Annual Review of Entomology, v.39, p.293-322, 1994.

HALL, I.M.; HUNTER, D.K.; ARAKAWA, K.Y. The effect of the $\beta$-exotoxin fraction of Bacillus thuringiensis on the citrus red mite. Journal of Invertebrate Pathology, v.18, p.359-362, 1971.

HANCHINAL, S.G.; MANJUNATHA, M. Metarhizium anisopliae (Metsch.) Sor. on Tetranychus neocaledonicus Andre and its predator Amblyseius ovalis Evans. Karnataka Journal of Agricultural Sciences, v.13, n.2, p.454-456, 2000.

HASSAN, S.A.; ALBERT, R.; BIGLER, F.; BLAISINGER, P.; BOGENSCHÜTZ, H.; BOLLER, E.; BRUN, J.; CHIVERTON, P.; EDWARDS, P.; ENGLERT, W.D.; HUANG, P.; INGLESFIELD, C.; NATON, E.; OOMEN, P.A.; OVERMEER, W.P.J.; RIECKMANN, W.; SAMSOE-PETERSEN, L.; STÄUBLI, A.; TUSET, J.J.; VIGGIANI, G.; VANWETSWINKEL, G. Results of third joint pesticide testing programme by the IOCB/WPRS - Working Group "Pesticides and Beneficial Organisms”. Journal of Applied Entomology, v.103, p.92-107, 1987.

HASSAN, S.A.; BIGLER, F.; BOGENSCHÜTZ, H.; BOLLER, E.; BRUN, J.; CHIVERTON, P.; EDWARDS, P.; MANSOUR, F.; NATON, E.; OOMEN, P.A.; OVERMEER, W.P.J.; POLGAR, L.; RIECKMANN, W.; SAMSOE-PETERSEN, L.; STÄUBLI, A.; STERK, G.; TAVARES, K.; TUSET, J.J.; VIGGIANI, G.; VIVAS, A.G. Results of fourth joint pesticide testing programme carried out by the IOCB/WPRS - Working Group "Pesticides and Beneficial Organisms". Journal of Applied Entomology, v.105, p.321-329, 1988. 
HASSAN, S.A.; BIGLER, F.; BOGENSCHÜTZ, H.; BOLLER, E.; BRUN, J.; CALIS, J.N.M.; CHIVERTON, P.; CORESMANS-PELSENEER, J.; DUSO, C.; LEWIS, G.B.; MANSOUR, F.; MORETH, L.; OOMEN, P.A.; OVERMEER, W.P.J.; POLGAR，L.; RIECKMANN，W.; SAMSOE-PETERSEN，L.; STÄUBLI，A.; STERK, G.; TAVARES, K.; TUSET, J.J.; VIGGIANI, G. Results of fifth joint pesticide testing programme carried out by the IOCB/WPRS - Working Group "Pesticides and Beneficial Organisms". Entomophaga, v.36, n.1, p.55-67, 1991.

HASSAN, S.A.; BIGLER, F.; BOGENSCHÜTZ, H.; BOLLER, E.; BRUN, J.; CALIS, J.N.M.; CORESMANS-PELSENEER, J.; DUSO, C.; GROVE, A.; HEIMBACH, U.; HELYER, N.; HOKKANEN, H.; LEWIS, G.B.; MANSOUR, F.; MORETH, L.; POLGAR, L.; SAMSOE-PETERSEN, L.; SAUPHANOR, B.; STÄUBLI, A.; STERK, G.; VAINIO, A.; van de VEIRE, M.; VIGGIANI, G.; VOGT, H. Results of sixth joint pesticide testing programme of the IOCB/WPRS - Working Group “Pesticides and Beneficial Organisms". Entomophaga, v.39, n.1, p.107-119, 1994.

HEGEDUS, D.D.; BIDOCHKA, M.J.; KHACHATOURIANS, G.G. Beauveria bassiana submerged conidia prodution in a defined medium containing chitin, two hexosamines or glucose. Applied Microbiology and Biotechnology, v.33, n.6, p.641-647, 1990.

HEGEDUS, D.D.; BIDOCHKA, M.J.; MIRANPURI, G.S.; KHACHATOURIANS, G.G. A comparison of the virulence, stability and cell-wall-surface characteristics of three spore types produced by the entomopathogenic fungus Beauveria bassiana. Applied Microbiology and Biotechnology, v.36, n.6, p.785-789, 1992.

HELYER, N. Verticillium lecanii for control of aphids and thrips on cucumber. Bulletin OILB-SROP, v.16, n.2, p.63-66, 1993. 
HELYER, N.; GILL, G.; BYWATER, A. Control of chrysanthemum pests with Verticillium lecanii. Phytoparasitica, suppl.20, p.5-9, 1992.

HENDERSON, C.F.; TILTON, E.W. Tests with acaricides against the brown wheat mite. Journal of Economic Entomology, v.48, p.157-161, 1955.

HOY, M.A.; OUYANG, Y. Toxicity of the $\beta$-exotoxin of Bacillus thuringiensis to Tetranychus pacificus and Metaseiulus occidentalis (Acari: Tetranychidae and Phytoseiidae). Journal of Economic Entomology, v.80, n.2, p.507-511, 1987.

HUMBER, R.A.; MORAES, G.J; SANTOS, J.M. Natural infection of Tetranychus evansi (Acarina: Tetranychidae) by a Triplosporium sp. (Zygomycetes: Entomophthorales) in Northeastern Brazil. Entomophaga, v.26, n.4, p. 421-425, 1981.

INGLIS, P.W.; TIGANO, M.S.; VALADARES-INGLIS, M.C. Transformation of the entomopathogenic fungi, Paecilomyces fumosoroseus and Paecilomyces lilacinus (Deuteromycotina: Hyphomycetes) to benomyl resistence. Genetics and Molecular Biology, v.22, n.1, p.119-123, 1999.

JACKSON, M.A.; McGUIRE, M.R.; LACEY, L.A.; WRAIGHT, S.P. Liquid culture production of desiccation tolerant blastospores of the bioinsecticidal fungus Paecilomyces fumosoroseus. Mycological Research, v.101, n.1, p.35-41, 1997.

JACOBSON, R.J.; CROFT, P.; FENLON, J. Response to fenbutatin oxide in populations of Tetranychus urticae Kock (Acari: Tetranychidae) in UK protected crops. Crop Protection, v.18, p.47-52, 1999.

JARVIS, W.R. Managing diseases in greenhouse crops. St. Paul: American Phytopathological Society Press, 1993. 288p. 
JEPPSON, L.R.; KEIFER, H.H.; BAKER, E.W. Mites injurious to economic plants. Berkeley: University of California Press, 1975. 614p.

KENNEDY, G.G.; SMITLEY, D.R. Dispersal. In: HELLE, W.; SABELIS, M.W. (Ed.). Spider mites. their biology, natural enemies and control. Amsterdam: Elsevier, 1985. v.1A, cap.1.4.2. p.233-242.

KENNETH, R.; MUTTATH, T.I.; GERSON, U. Hirsutella thompsonii, a fungal pathogen of mites. I. Biology of the fungus in vitro. Annals of Applied Biology, v.91, n.1, p.21-28, 1979.

KENNETH, R.; WALliS, G.; GERSON, U.; PLAUT, H.N. Observations and experiments on Triplosporium floridanum (Entomophthorales) attacking spider mites in Israel. Journal of Invertebrate Pathology, v.19, p.366-369, 1972.

KUROZAWA, C.; PAVAN, M.A. Doenças das cucurbitaceas. In: KIMATI, H.; AMORIM, L.; BERGAMIN FILHO, A.; CAMARGO, L.E.A.; REZENDE, J.A.M. (Ed.). Manual de fitopatologia: doenças das plantas cultivadas. São Paulo: Agronômica Ceres, 1997a. v.2, cap.29. p.325-337.

KUROZAWA, C.; PAVAN, M.A. Doenças do tomateiro. In: KIMATI, H.; AMORIM, L.; BERGAMIN FILHO, A.; CAMARGO, L.E.A.; REZENDE, J.A.M. (Ed.). Manual de fitopatologia: doenças das plantas cultivadas. São Paulo: Agronômica Ceres, 1997b. v.2, cap.64. p.690-719.

LACEY, L.A.; FRUTOS, R.; KAYA, H.K.; VAIL, P. Insect pathogens as biological control agents: do they have a future. Biological Control, v.21, n.3, p.230-248, 2001 . 
LANE, B.S.; TRINCI, A.P.J.; GILLESPIE, A.T. Endogenous reserves and survival of blastospores of Beauveria bassiana harvested from carbon and nitrogen limited batch cultures. Mycological Research, v.95, n.7, p.821-828, 1991a.

LANE, B.S.; TRINCI, A.P.J.; GILLESPIE, A.T. Influence of cultural conditions on the virulence of conidia and blastospores of Beauveria bassiana to the green leafhopper, Nephotettis virescens. Mycological Research, v.95, n.7, p.829-833, $1991 \mathrm{~b}$.

LeOra SOFTWARE. POLO-PC. A user's guide to probit and logit analysis. Berkeley, 1987. 22p.

LI, D.P.; HOLDOM, D.G. Effects of nutrients on colony formation, growth, and sporulation of Metarhizium anisopliae (Deuteromycotina: Hyphomycetes). Journal of Invertebrate Pathology, v.65, p.253-260, 1995.

LIMA, E.A.L.A.; TIGANO, M.S. Citologia das estruturas leveduriformes de Beauveria bassiana em meio de cultura líquido e na hemolinfa de Spodoptera frugiperda. Revista de Microbiologia, v.20, n.1, p.85-94, 1989.

LIPA, J.J. Microbial control of mites and ticks. In: BURGES, H.D.; HUSSEY, W.W. (Ed.). Microbial control of insects and mites. London: Academic Press, 1971. p.357-373.

LIU, Z.Y.; MILNER, R.J.; McRAE, C.F.; LUTTON, G.G. The use of dodine in selective media for the isolation of Metarhizium spp. from soil. Journal of Invertebrate Pathology, v.62, p.248-251, 1993. 
LOPES, R.B. Seleção de fungos entomopatogênicos e controle de Frankliniella occidentalis (Thysanoptera: Thripidae). Piracicaba, 1999. 76p. Dissertação (Mestrado) - Escola Superior de Agricultura "Luiz de Queiroz", Universidade de São Paulo.

LOPES, R.B.; ALVES, S.B.; TAMAI, M.A. Fungo Metarhizium anisopliae (Metsch.) Sorokin e o controle de Frankliniella occidentalis (Pergande) (Thysanoptera: Thripidae) em alface hidropônico. Scientia Agricola, v.57, n.2, p.239-243, 2000.

MACEDO, D.; TANZINI, M.R.; ALVES, S.B. Fases de desenvolvimento de Verticillium lecanii em Brevipalpus phoenicis. In: SIMPÓSIO DE CONTROLE BIOLÓGICO, 7., Poços de Caldas, 2001. Resumos. Lavras: UFLA, 2001. p.243.

McCOY, C.W. Pest control by the fungus Hirsutella thompsonii. In: BURGES, H.D. (Ed.). Microbial control of insects, mites and plant diseases. London: Academic Press, 1981. v.2, cap.26, p.499-512.

McCOY, C.W.; COUCH, T.I. Hirsutella thompsonii: A potencial mycoacaricide. Developments in Industrial Microbiology, v.20, p.89-96, 1978.

McCOY, C.W.; COUCH, T.L. Microbial control of the citrus rust mite with the mycoacaricide, Mycar ${ }^{\circledR}$. Florida Entomologist, v.65, n.1, p.116-126, 1982.

McCOY, C.W.; HEIMPEL, A.M. Safety of the potential mycoacaricide, Hirsutella thompsonii, to vertebrates. Environmental Entomology, v.9, n.1, p.47-49, 1980.

MIRANPURI, G.S.; KHACHATOURIANS, G.G. Pathogenicity of Beauveria bassiana (Bals.) Vuill. and Verticillium lecanii (Zimm.) toward blister beetle, Lytta nuttali Say (Col., Meloidae). Journal of Applied Entomology, v.118, n.1, p.103-110, 1994. 
MOINO JÚNIOR, A. Fatores que afetam ao eficiência de Beauveria bassiana (Bals.) Vuill. e Metarhizium anisopliae (Metsch.) Sorok. no controle de Heterotermes tenuis (Isoptera, Rhinotermitidae). Piracicaba, 1998. 134p. Tese (Doutorado) - Escola Superior de Agricultura “Luiz de Queiroz”, Universidade de São Paulo.

MORAES, G.J.; DELALIBERA JÚNIOR, I. Specificity of a strain of Neozygites sp. (Zygomycetes: Entomophthorales) to Mononychellus tanajoa (Acari: Tetranychidae). Experimental and Applied Acarology, v.14, p.89-94, 1992.

MUMA, M.H. Factors contributing to the natural control of citrus insects and mites in Florida. Journal of Economic Entomology, v.48, n.4, p.432-438, 1955.

MUNGER, F.; GILMORE, J.E.; DAVIS, W.S. A disease of citrus red mites. California Citrograph, v.44, p.190-216, 1959.

MURPHY, B.C.; MORISAWA, T.A.; NEWMAN, J.P.; TJOSVOLD, S.A.; PARRELLA, M.P. Fungal pathogen controls thrips in greenhouse flowers. California Agriculture, v.52, n.3, p.32-36, 1998.

NEMOTO, H.; AOKI, J. Entomophthora floridana (Entomophthorales: Entomophthoraceae) attacking the sugi spider mite, Oligonychus hondoensis (Acarina: Tetranychidae), in Japan. Applied Entomology and Zoology, v.10, n.2, p. $90-95,1975$.

NEVES, P.J.; ALVES, S.B. Grooming capacity inhibition in Cornitermes cumulans (Kollar) (Isoptera: Termitidae) inoculated with entomopathogenic fungi and treated with imidacloprid. Anais da Sociedade Entomologica do Brasil, v.29, n.3, p.537-545, 2000a. 
NEVES, P.J.; ALVES, S.B. Selection of Beauveria bassiana (Bals.) Vuill. and Metarhizium anisopliae (Metsch.) Sorok. strains for control of Cornitermes cumulans (Kollar). Brazilian Archives of Biology Technology, v.43, n.4, p.373-378, 2000b.

NEVES, P.J.; TAMAI, M.A.; ALVES, S.B. Processo de infecção e reprodução de Beauveria bassiana em Tetranychus urticae (Koch) (Acari, Tetranychidae). In: CONGRESSO BRASILEIRO DE ENTOMOLOGIA, 16., ENCONTRO NACIONAL DE FITOSSANITARISTAS, 7., Salvador, 1997. Anais. Salvador: SEB, 1997. p.138-139.

NORTON, R.A.; BEHAN-PELLETIER, V.M. Calcium carbonate and calcium oxalate as cuticular hardening agents in oribatid (Acari: Oribatida). Canadian Journal of Zoology, v.69, n.6, p.1504-1511, 1991.

ODUOR, G.I.; MORAES, G.J.; VAN DER GEEST, L.P.S.; YANINEK, J.S. Production and germination of primary conidia of Neozygites floridana (Zygomycetes: Entomophthorales) under constant temperatures, humidities and photoperiods. Journal of Invertebrate Pathology, v.68, n.3, p.213-222, 1996a.

ODUOR, G.I.; YANINEK, J.S.; MORAES, G.J.; VAN DER GEEST, L.P.S. The effect of pathogen dosage on the pathogenicity of Neozygites floridana (Zygomycetes: Entomophthorales) to Mononychellus tanajoa (Acari: Tetranychidae). Journal of Invertebrate Pathology, v.70, n.2, p.127-130, 1997.

ODUOR, G.I.; YANINEK, J.S.; VAN DER GEEST, L.P.S.; MORAES, G.J. Survival of Neozygites cf. floridana (Zygomycetes: Entomophthorales) in mummified cassava green mites and the viability of its primary conidia. Experimental and Applied Acarology, v.19, n.9, 479-488, 1995. 
ODUOR, G.I.; YANINEK, J.S.; VAN DER GEEST, L.P.S.; MORAES, G.J. Germination and viability of capiliconidia of Neozygites floridana (Zygomycetes: Entomophthorales) under constant temperature, humidity and light conditions. Journal of Invertebrate Pathology, v.67, n.3, p.267-278, 1996b.

OLIVEIRA, M.R.V. O emprego de casas de vegetação no Brasil: vantagens e desvantagens. Pesquisa Agropecuária Brasileira, v.30, n.8, p.1049-1060, 1995.

OLIVEIRA, R.C.; ALVES, L.F.A.; GAIS, N.L. Virulence of Beauveria bassiana isolates to Oligonychus yothersi (Acari: Tetranychidae). In: INTERNATIONAL CONGRESS OF ENTOMOLOGY, 21., Foz do Iguaçú, 2000. Abstracts. Book 1. Londrina: EMBRAPA Soja, 2000. p.534.

OLMERT, I.; KENNETH, R.G. Sensitivity of the entomopathogenic fungi, Beauveria bassiana, Verticillium lecanii, and Verticillium sp. to fungicides and insecticides. Environmental Entomology, v.3, p.33-39, 1974.

OMOTO, C. Modo de ação de inseticidas e resistência de insetos a inseticidas. In: GUEDES, J.C.; COSTA, I.D.; CASTIGLIONI, E. (Org.). Bases e técnicas do manejo de insetos. Santa Maria: Pallotti, 2000, cap.2, p.31-49.

OMOTO, C.; ALVES, S.B. Mecanismos de defesa de insetos contra entomopatógenos. In: ALVES, S.B. (Ed.). Controle microbiano de insetos. 2.ed. Piracicaba: FEALQ, 1998. cap.3, p.55-73.

PACCOLA-MEIRELLES, L.D.; AZEVEDO, J.L. Variabilidade natural no fungo entomopatogênico Beauveria bassiana. Arquivos de Biologia e Tecnologia, v.33, n.3, p.657-672, 1990. 
PELAGATTI, O.; FRATE, G.; CARETTA, G. Funghi isolati da insetti e acari. Redia, v.71, p.255-266, 1988.

PENA, J.E.; OSBORNE, L.S.; DUNCAN, R.E. Potential of fungi as biocontrol agents of Polyphagotarsonemus latus (Acari: Tarsonemidae). Entomophaga, v.41, n.1, p.27-36, 1996.

PENDLAND, J.C.; BOUCIAS, D.G. In vitro growth of the entomopathogenic hyphomycete Nomuraea rileyi. Mycologia, v.89. n.1, p.66-71, 1997.

PEREIRA, R.M.; ALVES, S.B.; SOSA-GÓMES, D.R.; MACEDO, N. Utilização de entomopatógenos no manejo integrado de pragas. In ALVES, S.B. (Ed.). Controle microbiano de insetos. 2.ed. Piracicaba: FEALQ, 1998. cap.38, p.1097-1118.

PUTMAN, W.L. Occurrence and transmission of a virus disease of the European red mite, Panonychus ulmi. Canadian Entomologist, v.102, p.305-321, 1970.

PUTMAN, W.L.; HERNE, D.H.C. The role of predators and other biotic agents in regulating the population density of phytophagous mites in Ontario peach orchards. Canadian Entomologist, v.98, p.808-820, 1966.

QUINTELA, E.D.; McCOY, C.W. Synergistic effect of imidacloprid and two entomopathogenic fungi on the behavior and survival of larvae of Diaprepes abbreviatus (Coleoptera: Curculionidae) in soil. Journal of Economic Entomology, v.91, n.1, p.110-122, 1998.

RAMASESHIAH, G. Occurrence of an Entomophthora on Tetranychid mites in India. Journal of Invertebrate Pathology, v.18, p.421-424, 1971. 
RAMOS, E.Q. Seleção de isolados de fungos entomopatogênicos para o controle de Bemisia tabaci biótipo "B". Piracicaba, 2001. 57p. Dissertação (Mestrado) Escola Superior de Agricultura “Luiz de Queiroz”, Universidade de São Paulo.

RAMOS, E.Q.; ALVES, S.B. Seleção de fungos entomopatogênicos para o controle de Bemisia tabaci biótipo "B". In: SIMPÓSIO DE CONTROLE BIOLÓGICO, 7., Poços de Caldas, 2001. Resumos. Lavras: UFLA, 2001. p.404.

REED, D.K. Control of mites by non-occluded viruses. In: Burges, H.D. (Ed.). Microbial control of pest and plant diseases 1970-1980. New York: Academic Press, 1981. p.427-432.

REED, D.K. Effects of temperature on virus-host relationships and on activity of the noninclusion virus of citrus red mites, Panonychus citri. Journal of Invertebrate Pathology, v.24, p.218-223, 1974.

REED, D.K.; HALL, I.M. Electron microscopy of a rod-shaped non-inclusion virus infecting the citrus red mite. Journal of Invertebrate Pathology, v.20, n.3, p.272278, 1972.

REED, D.K.; RICH, J.E.; SHAW, J.G. A portable apparatus for detection of virusdiseased citrus red mites in the field. Journal of Economic Entomology, v.65, n.3, p.890-891, 1972a.

REED, D.K.; SHAW, J.G.; RICH, J.E. Increased infection through laboratory culturing of citrus red mites collected from diseased populations. Journal of Economic Entomology, v.65, n.5, p.1507, 1972b. 
RETNAKARAN, A.; GRANETT, J.; ENNIS, T. Insect growth regulators. In: KERKUT, G.A.; GILBERT, L.I. Comprehensive insect physiology biochemistry and pharmacology. New York: Pergamon Press, 1985. v.12, p.529-601.

ROBERTS, D.W.; KRASNOFF, S.B. Toxinas e enzimas de fungos entomopatogênicos. In: ALVES, S.B. (Ed.). Controle microbiano de insetos. 2.ed. Piracicaba: FEALQ, 1998. cap.32, p.967-985.

ROSSI, L.S.; ALVES, S.B.; TAMAI, M.A.; CASTIGLIONI, E. Patogenicidade de Beauveria bassiana ao ácaro Phyllocoptruta oleivora Ashmed. In: SIMPÓSIO DE CONTROle BIOLÓGICO, 7., Poços de Caldas, 2001. Resumos. Lavras: UFLA, 2001. p.352.

ROYALTY, R.N.; HALL, F.R.; TAYLOR, R.A.J. Effects of thuringiensin on Tetranychus urticae (Acari: Tetranychidae) mortality, fecundity, and feeding. Journal of Economic Entomology, v.38, n.3, p.792-798, 1990.

SAMSON, R.A.; EVANS, H.C.; LATGÉ, J.P. Atlas of entomopathogenic fungi. Springer-Verlag, 1988. 187p.

SELHIME, A.G.; MUMA, M.H. Biology of Entomophthora floridana attacking Eutetranychus banksi. Florida Entomologist, v.49, n.3, p.161-168, 1966.

SEWIFY, G.H.; MABROUK, A.M. The susceptibility of different stages of the citrus brown mite, Eutetranychus orientalis Oudemans (Acarina: Tetranychidae) to entomopathogenic fungus, Verticillium lecanii (Zimm.) Viegas. In: INTERNATIONAL COLLOQUIUM ON INVERTEBRATE PATHOLOGY AND MICROBIAL CONTROL, 5., Adelaide, 1990. Proceedings and abstracts. Adelaide: SIP, 1990. p.395. 
SHAH, P.A.; GOETTEL, M.S. Directory of microbial control products and services. Society for Invertebrate Pathology, Division of Microbial Control. http://www.sipweb.org/directory.htm (18 jan. 1999).

SHANNON, P.J. Hongos entomopatógenos. In: HILJE, L. (Ed.). Metodologias para el estudio y manejo de moscas blancas y geminivirus. Turrialba: CATIE, 1996. cap.7, p.60-68.

SHAW, J.G.; CHAMBERS, D.L.; TASHIRO, H. Introducing and establishing the noninclusion virus of the citrus red mite in citrus groves. Journal of Economic Entomology, v.61, n.5, p.1352-1355, 1968a.

SHAW, J.G.; REED, D.K.; STEWART, J.R.; GORDEN, J.M.; RICH, J.E. Mechanical collection of diseased citrus red mites as a method of providing inoculum. Journal of Economic Entomology, v.64, n.5, p.1223-1224, 1971.

SHAW, J.G.; TASHIRO, H.; DIETRICK, E.J. Infection of the citrus red mite with virus in central and southern California. Journal of Economic Entomology, v.61, n.6, p.1492-1495, $1968 b$.

SHIPP, J.L.; WANG, K.; FERGUSON, G. Residual toxicity of avermectin b1 and pyridaben to eight commercially produced beneficial arthropod species used for control of greenhouse pests. Biological Control, v.17, p.125-131, 2000.

SMITH, K.M.; HILLS, G.J.; MUNGER, F.; GILMORE, J.E. A suspected virus disease of the citrus red mite Panonychus citri (McG.). Nature, v.184, p.70, 1959. 
SMITLEY, D.R.; BROOKS, W.M.; KENNEDY, G.G. Environmental effects on production of primary and secondary conidia, infection, and pathogenesis of Neozygites floridana, a pathogen of the twospotted spider mite, Tetranychus urticae. Journal of Invertebrate Pathology, v.47, p.325-332, 1986.

SOSA-GÓMEZ, D.R.; NASCA, A.J. Primera cita del hongo patógeno de ácaros, Hirsutella thompsonii (Fisher, 1950) para la República Argentina. CIRPON Revista de Investigacíon, v.1, n.3, p.137-141, 1983.

SOSA-GÓMEZ, D.R.; RICCI, J.G.; NASCA, A.J. Efecto de Hirsutella thompsonii Fisher var. thompsonii, sobre larvas y adultos de Coccidophilus citricola Brethes y Lindorus lophanthae (Blaisdell) (Col.; Coccinellidae). CIRPON - Revista de Investigacíon, v. 3, n. 1/2, p. 73-77, 1985.

SPEARE, A.T.; YOTHERS, W.W. Is there an entomogenous fungus attacking the citrus rust mite in Florida?. Science, v.11, p.41-42, 1924.

STEINHAUS, E.A. Possible virus disease in European red mite. Journal of Invertebrate Pathology, v.1, p.435-437, 1959.

STERK, G.; HASSAN, S.A.; BAILLOD, M.; BAKKER, F.; BIGLER, F.; BRÜMEL, S.; BOGENSCHÜTZ, H.; BOLLER, E.; BROMAND, B.; BRUN, J.; CALIS, J.N.M.; CORESMANS-PELSENEER, J.; DUSO, C.; GARRIDO, A.; GROVE, A.; HEIMBACH, U.; HOKKANEN, H.; JACAS, J.; LEWIS, G.B.; MORETH, L.; POLGAR, L.; ROVERSTI, L.; SAMSOE-PETERSEN, L.; SAUPHANOR, B.; SCHAUB, L.; STÄUBLI, A.; TUSET, J.J.; VAINIO, A.; van de VEIRE, M.; VIGGIANI, G.; VIÑUELA, E.; VOGT, H. Results of seventh joint pesticide testing programme carried out by the IOCB/WPRS - Working Group "Pesticides and Beneficial Organisms”. BioControl, v.44, p.99-117, 1999. 
SUSILO, F.X.; NORDIN, G.L.; BROWN, G.C. Age-specific and inter-sexual susceptibility of two-spotted spider mite, Tetranychus urticae Koch, to Neozygites floridana Weiser and Muma. Journal of the Kansas Entomological Society, v.67, n.3, p.293-296, 1994.

TAMAI, M.A. Avaliação de fungos entomopatogênicos para o controle de Tetranychus urticae Koch. Piracicaba, 1998. 86p. Dissertação (Mestrado) - Escola Superior de Agricultura "Luiz de Queiroz", Universidade de São Paulo.

TAMAI, M.A.; ALVES, S.B.; NEVES, P.J. Patogenicidade de Beauveria bassiana (Bals.) Vuill. ao ácaro Tetranychus urticae Koch. Scientia Agricola, v.56, n.1, p.285-288, 1999.

TAMAI, M.A.; LOPES, R.B.; ALVES, S.B. Manejo de pragas na floricultura. In: REUNIÃO ITINERANTE DE FITOSSANIDADE DO INSTITUTO BIOLÓGICO, 3., Mogi das Cruzes, 2000. Anais. Campinas: IB, 2000. p.77-82.

TANAKA, M.A.S.; BETTI, J.A.; KIMATI, H. Doenças do morangueiro. In: KIMATI, H.; AMORIM, L.; BERGAMIN FILHO, A.; CAMARGO, L.E.A.; REZENDE, J.A.M. (Ed.). Manual de fitopatologia: doenças das plantas cultivadas. São Paulo: Agronômica Ceres, 1997. v.2, cap.35, p.556-571.

TANZINI, M.R.; ALVES, S.B.; MORAES, G.J.; TAMAI, M.A.; FERLA, N.J. An epizootic of Calacarus heveae (Acari: Eriophyidae) caused by Hirsutella thompsonii F. on rubber trees. Experimental and Applied Acarology, v.24, n.2, p.141-144, 2000.

TASHIRO, H.; BEAVERS, J.B. Field epizootic of the citrus red mite virus disease. California Citrograph, v.51, n.12, p.503-506, 1966. 
TIXIER, C.; BOGAERTS, P.; SANCELME, M.; BONNEMOY, F.; TWAGILIMANA, L.; CUER, A.; BOHATIER, J.; VESCHAMBRE, H. Fungal biodegradation of a phenylurea herbicide, diuron: structure and toxicity of metabolites. Pest Management Science, v.56, p.455-462, 2000.

TODOROVA, S.I.; CODERRE, D.; DUCHESNE, R.M.; CÔTÉ, J.C. Compatibility of Beauveria bassiana with selected fungicides and herbicides. Environmental Entomology, v.27, n.2, p.427-433, 1998.

VAN DE VRIE, M. Greenhouse ornamentals. In: HELLE, W.; SABELIS, M.W. (Ed.). Spider mites. their biology, natural enemies and control. Amsterdam: Elsevier, 1985. v.1B, cap.3.2.1. p.273-283.

VAN DER GEEST, L.P.S. Pathogens of spider mites. In: HELLE, W.; SABELIS, M.W. (Ed.). Spider mites. their biology, natural enemies and control. Amsterdam: Elsevier, 1985. v.1B, cap.2.4, p.247-258.

VAN DER GEEST, L.P.S.; ELLIOT, S.L.; BREEUWER, J.A.J.; BEERLING, E.A.M. Diseases of mites. Experimental and Applied Acarology, v.24, n.7, p.497-560, 2000.

VAN LENTEREN, J.C. A greenhouse without pesticides: fact or fantasy? Crop Protection, v.19, p.375-384, 2000.

VAN LENTEREN, J.C. Integrated pest management in protected crops. In: DENT, D. Integrated pest management. London: Chapman \& Hall, 1995. cap.12, p.311-343.

VAN LENTEREN, J.C.; WOETS, J. Biological and integrated pest control in greenhouses. Annual Review of Entomology, v.33, p.239-269, 1988. 
VAN LENTEREN, J.C.; ROSKAM, M.M.; TIMMER, R. Commercial mass production and pricing of organisms for biological control of pests in Europe. Biological Control, v.10, p.143-149, 1997.

VANDENBERG, J.D.; JACKSON, M.A.; LACEY, L.A. Relative efficacy of blastospores and aerial conidia of Paecilomyces fumosoroseus against the russian wheat aphid. Journal of Invertebrate Pathology, v.72, n.2, p.181-183, 1998.

VEHRS, S.L.; PARRELLA, M.P. Aphid problems increase on ornamentals. California Agriculture, v.45, n.1, p.28-29, 1991.

VILLAS BÔAS, G.L. Métodos de controle de pragas em hortaliças. Horticultura Brasileira, v.7, n.1, p.3-6, 1989.

WILDING, N. Pest control by Entomophthorales. In: BURGES, H.D. (Ed.). Microbial control of pest and plant diseases. London: Academic Press, 1981. cap.28, p.539554.

YAMAMOTO, P.T.; PINTO, A.S.; PAIVA, P.E.B.; GRAVENA, S. Seletividade de agrotóxicos aos inimigos naturais de pragas dos citros. Laranja, v.13, p.709-755, 1992.

YANINEK, J.S.; MORAES, G.J. A synopsis of classical biological control of mites in agriculture. In: DUSBABECK, F.; BUKVA, V. (Ed.). Modern acarology. Prague: SPB Academic Publ., 1991. cap.5.1, p.133-149.

YANINEK, J.S.; SAIZONOU, S.; ONZO, A.; ZANNOU, I.; GNANVOSSOU, D. Seasonal and habitat variability in the fungal pathogens, Neozygites cf. floridana and Hirsutella thompsonii, associated with cassava green mites in Benin, West Africa. Biocontrol Science and Technology, v.6, n.1, p.23-33, 1996. 
ZAMBOLIM, L.; COSTA, H.; LOPES, C.A.; VALE, F.X.R. Doenças de hortaliças em cultivo protegido. Informe Agropecuário, v.20, n.200/201, p.114-125, 1999.

ZOEBISCH, T.G.; OCHOA, R.; VARGAS, C.; GAMBOA, A. Identificacion y potencial del hongo Hirsutella thompsonii Fisher para el control de acaros de importancia economica en America Central. Manejo Integrado de Plagas, n.23, p.9-12, 1992. 